\title{
Horizontalidade e verticalidade: dois modelos de improvisação no choro brasileiro
}

\author{
Paula Veneziano Valente
}

Dissertação apresentada ao programa de música - Área de Concentração: Processos de Criação Musical, da Escola de Comunicações e Artes da Universidade de São Paulo, como requisito para a obtenção do título de Mestre.

Orientador:

Prof. Dr. Rogério Luis Moraes Costa 
Banca Examinadora 


\section{Agradecimentos}

Ao Prof. Dr. Rogério Costa, pela competente orientação e atenção;

A Gilka Barros pela generosidade e disposição em ajudar sempre;

A Cristina Machado, pelo primeiro "empurrão" e constante entusiasmo;

Aos amigos Cláudio Bazzoni e Guca Domênico pelas contribuições "literárias", e a Débora Gurgel pelas “musicais”;

Ao Proveta que, mesmo sem saber, me abriu caminhos sugerindo a idéia inicial deste trabalho;

A Camila Bomfim, pela amizade e colaboração nas revisões e formatação;

A Maria Lígia Prado, pela boa vontade e pelas contribuições fundamentais na estruturação desta pesquisa;

Ao meu filho Lucas;

Ao Fabio, pelo apoio e carinho, em todos os momentos. 


\section{RESUMO}

O objetivo deste trabalho, de cunho essencialmente musicológico, é analisar comparativamente dois estilos de improvisação no choro brasileiro. Para este estudo foram escolhidos dois importantes nomes da música popular brasileira: Pixinguinha e K-Ximbinho. Com base nos conceitos propostos por George Russell sobre abordagem horizontal e vertical, caracterizamos os respectivos estilos e investigamos os diferentes caminhos percorridos por eles a fim de determinar as abordagens que cada um deles privilegia. Esta pesquisa apresenta ainda um sentido pedagógico, pois pretende estimular professores e estudantes de improvisação a pensar de maneira criativa as estruturas musicais, ao identificar dois modelos que podem ser utilizados como ferramentas de estudo para o desenvolvimento deste procedimento.

Palavras-chave: Pixinguinha, K-Ximbinho, Improvisação, Música Popular Brasileira, Choro. 


\section{ABSTRACT}

The nature of this paper is essentially musical and its sole purpose is to deal with a comparative study of two different styles of improvisation which can be found in one of the rhythms typical of Brazilian popular music: The "choro". Two main Brazilian musicians have been chosen to illustrate the techniques used. The first one is known as Pixinguinha and the other is $\mathrm{K}$ - Ximbinho. By analyzing both artists' work one hopes to be able to establish the differences between the two models. On the other hand, this paper intends to inspire teachers and students to think in a creative manner identifying the two models - horizontal and vertical structures.

Keywords: Pixinguinha, K-Ximbinho, Improvisação, Música Popular Brasileira, Choro. 


\section{SUMÁRIO}

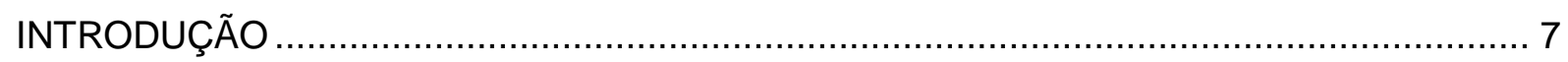

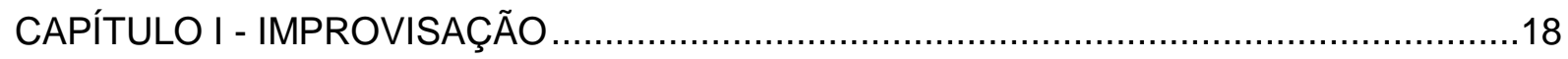

1 - Definições.

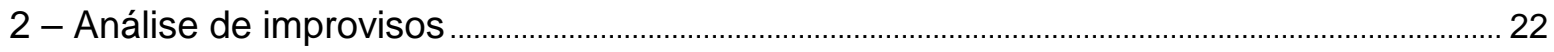

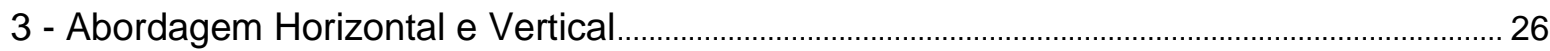

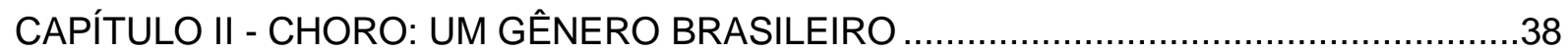

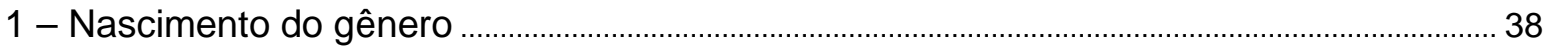

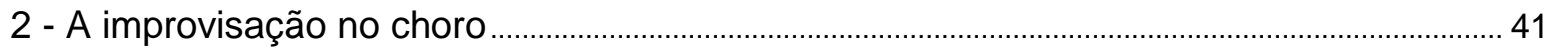

3 - A função dos instrumentos no grupo de choro e a "baixaria" ..................................................... 48

CAPÍTULO III - PIXINGUINHA E A "MODERNA" TRADIÇÃO BRASILEIRA .......................54



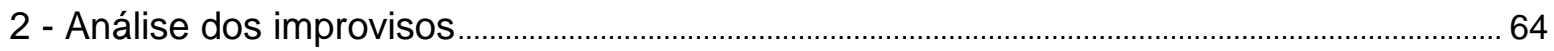

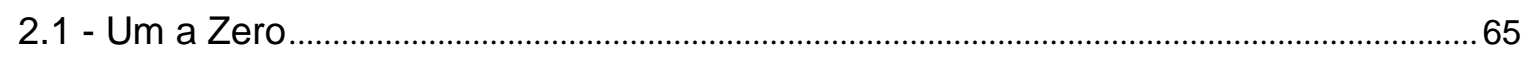

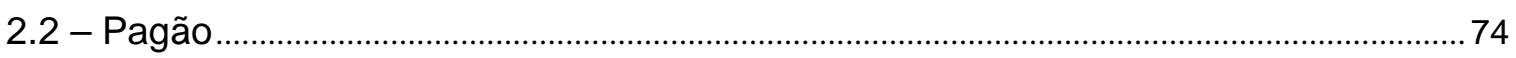

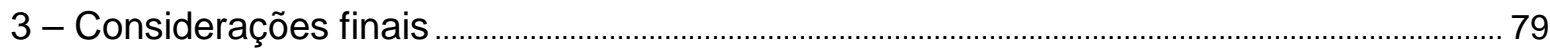

CAPÍTULO IV - K- XIMBINHO: ENTRE O CHORO E O JAZZ .......................................81

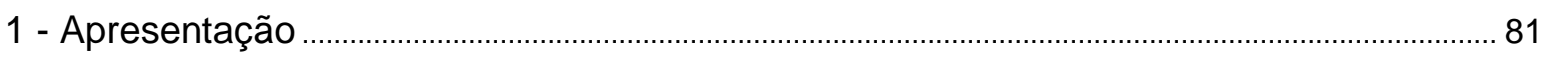

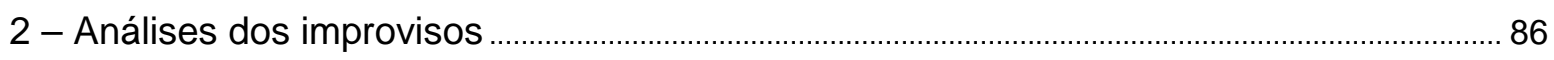

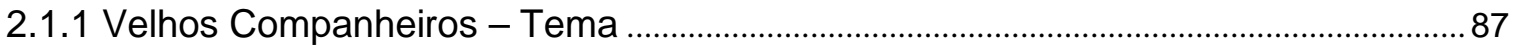

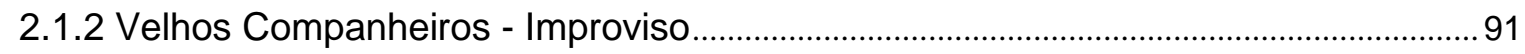

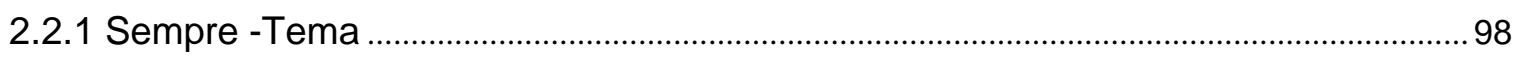

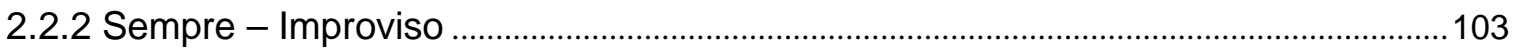

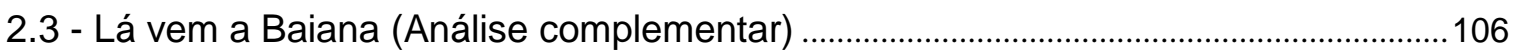

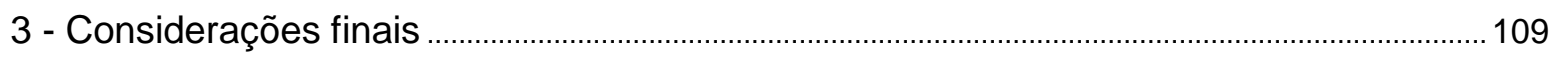

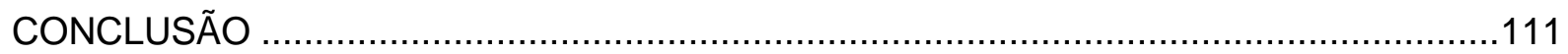

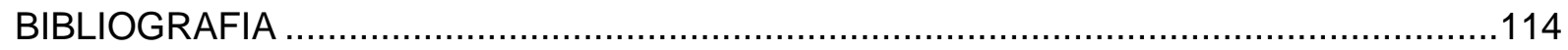

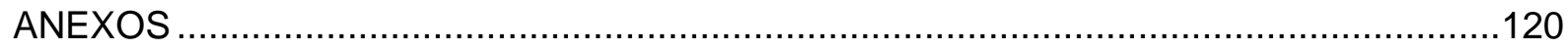




\section{INTRODUÇÃO}

Esta dissertação tem por objeto estudar a improvisação na música popular instrumental brasileira. A amplitude da temática nos obrigou a realizar um recorte. Assim, escolhemos dois importantes compositores e instrumentistas, Alfredo da Rocha Viana e Sebastião de Barros, mais conhecidos como Pixinguinha e KXimbinho, com o objetivo de realizar análises de alguns de seus improvisos, e por meio delas, apresentar as linhas básicas da condução melódica de cada autor durante a construção de um improviso. Essa investigação pretende encontrar modelos representativos dessas estruturas, e acreditamos que o reconhecimento dessas linhas ou "caminhos" de um improviso ajudará em futuras pesquisas referentes a esse tema, além de contribuir para o ensino da improvisação, já que pretendemos comentar aspectos dos processos de criação, fornecendo elementos que auxiliarão os estudantes em seu desenvolvimento. Outro importante objetivo será observar o grau de relevância e a verdadeira função da improvisação dentro da história do choro. Nosso interesse por este tema surgiu quando o músico e saxofonista Nailor "Proveta" ${ }^{1}$ citou a existência de duas tendências que, segundo ele, coexistem dentro do choro. A primeira estaria ligada aos baixos - influenciada pelas linhas graves que podemos ouvir nas primeiras gravações de choros $^{2}$-, ao caminho harmônico, ou como ele mesmo disse, simbolizada pela mão esquerda do piano; a outra voltada à mão direita, ou seja, à melodia, relacionada às extensões harmônicas. Passamos então a pesquisar, dentro do universo do choro, músicos e obras que poderiam traduzir essas tendências mais claramente.

Voltando à questão da improvisação, sua presença se faz notar na música brasileira em várias épocas e estilos, sempre com variações, tanto no que se refere ao grau de liberdade quanto à importância destas improvisações dentro do contexto geral da obra.

\footnotetext{
${ }^{1}$ Em depoimento à autora, sobre o tema da improvisação brasileira, realizada em abril de 2005.

2 Essas linhas a que nos referimos eram executadas pelos instrumentos graves de sopros (tuba, bombardino, trombone, etc.) ou pelos violões de 7 cordas; também chamadas de "baixarias" e que serão examinadas no primeiro capítulo.
} 
O improviso é um procedimento comum a vários estilos e épocas, possui grande importância dentro da criação musical brasileira, e ainda é pouco considerado pela musicologia nacional. Por serem relativamente recentes os estudos nesta área, existem poucas obras referentes a ele. Grande parte do material didático que temos disponível para o estudo da improvisação se refere à música americana, mais especificamente ao jazz, sendo raros os livros dedicados à música brasileira $^{3}$. O mercado americano de livros didáticos que se voltam para a improvisação é vasto, provavelmente este deva ser um dos motivos da grande influência da improvisação jazzística dentro da música brasileira. Tendo em vista essa insuficiência de pesquisas e materiais de estudo, aqueles que queiram se aprimorar na linguagem do choro e na improvisação, voltam-se necessariamente aos discos ou aos próprios músicos para construir seu aprendizado. Nesse sentido, a observação das gravações é determinante, pois nelas podemos perceber aspectos como articulação, dinâmica e inflexão.

Destacamos neste trabalho, dois importantes improvisadores da música popular brasileira: Pixinguinha e K-Ximbinho. Além de improvisadores, eles também foram intérpretes, compositores e arranjadores; no entanto, será tema da nossa pesquisa somente o aspecto referente à improvisação dentro de suas obras, e por meio de seus exemplos musicais investigaremos os principais caminhos e preferências de cada um deles.

Pixinguinha nasceu no Rio de Janeiro em 1897, onde viveu toda sua vida; faleceu em 1972. K-Ximbinho, vindo de Natal, cidade onde nasceu em 1917, também passou grande parte de sua vida no Rio de Janeiro, onde faleceu em 1981. Eles viveram em épocas diferentes, e receberam influências sócio-culturais diversas; essas diferenças se refletem em suas obras, tanto nas composições quanto nas improvisações e nos revelam as diferentes "escutas" de cada um deles. As distinções de suas concepções e de suas influências musicais são fundamentais para a nossa pesquisa, pois elas transparecem em seus improvisos, e, por meio deles, conseguiremos ilustrar diferentes procedimentos.

Em relação às influências observadas em cada um deles, notamos que para um músico popular, como no caso de Pixinguinha e K-Ximbinho, que circulavam por

\footnotetext{
${ }^{3}$ Um dos poucos livros sobre improvisação no choro é o Dicionário do Choro de Mário Seve, e mais recentemente Carlos Almada lançou A estrutura do choro: com aplicações na improvisação (2006).
} 
gêneros, estilos e performances variadas, sobreviver dentro do mercado de trabalho significava se adaptar aos gostos e modas do público e da época.

Tanto Pixinguinha quanto K-Ximbinho, sempre se ajustaram ao mercado, e compunham além de choros, outros estilos. Essa flexibilidade sempre fez parte da produção dos músicos brasileiros, e a assimilação das novidades estrangeiras muitas vezes se combinou às tendências musicais brasileiras. $O$ material sobre Pixinguinha é vasto, existem várias obras escritas sobre sua vida e obra; as mais importantes e, que utilizaremos nessa pesquisa, são a de Sergio Cabral Pixinguinha: Vida e Obra (1997) e Pixinguinha - Filho de Ogum Bexiguento de Silva e Oliveira Filho (1998). Além de obras escritas, sua discografia é ampla e bem catalogada podendo ser encontrado um grande acervo no I.M.S. (Instituto Moreira Sales).

Enquanto a obra de Pixinguinha já foi tema estudado, a de K- Ximbinho recebeu pouca atenção. Apesar de ter sido um compositor e instrumentista conceituado dentro da música brasileira, deparamo-nos com dificuldades em encontrar materiais sobre ele, tanto escritos quanto sonoros. A maioria de seus discos foram gravados junto à Orquestra Tabajara, de Severino Araújo, na qual atuou em grande parte de sua vida. Além dos discos com a Orquestra, gravou com outras formações menores ou também acompanhando importantes cantores de sua época. As gravações de K-Ximbinho estão dispersas e segundo nossas pesquisas somente seu último trabalho pode ser encontrado em CD.

A escolha desses nomes tem como principal motivo o fato de acreditarmos que eles representam dois modelos distintos de se estruturar a improvisação. As análises de seus improvisos nos ajudarão nesta diferenciação e classificação, ponto principal da pesquisa.

Estudando a vida e a obra desses dois grandes nomes da música popular brasileira, podemos listar alguns pontos em comum. Ambos foram intérpretes, compositores, arranjadores e regentes; participaram de muitas gravações e orquestras, tocaram nas rádios, bares e boates; tiveram uma intensa produção musical e profissional durante toda a vida, passando por vários momentos da história da música popular brasileira. Como compositor Pixinguinha deixou uma obra composta por aproximadamente mil músicas (Cravo Albin 2003, p. 550), e segundo 
Marília B. da Silva (1979) por volta de 330 inéditas. Já K-Ximbinho não possui uma obra tão extensa, não mais de 40 composições editadas, a maioria choros.

Pixinguinha foi considerado o primeiro grande improvisador no choro e segundo Cabral (1978, p.20): "Ele soube reunir uma série de elementos que andavam dispersos nas primeiras décadas do choro". Para alguns autores, ele consolidou um padrão de improvisação no choro.

K-Ximbinho pode ser considerado um exemplo da continuidade dessa prática criativa dentro da música brasileira, mesmo com uma obra não tão numerosa quanto à de Pixinguinha e de ser pouco estudado dentro das pesquisas acadêmicas até o presente momento.

Percebemos durante a criação de um improviso dois tipos básicos de caminhos: um que se revela mais preocupado com a harmonia, e outro com a melodia. Essas duas linhas coexistem no mesmo discurso, mas notamos a predominância de uma delas em relação à outra dependendo de cada intérprete. Nosso principal intuito é exemplificar estes caminhos por meio das análises dos compositores escolhidos, demonstrando as diferenças e semelhanças e traçar um modelo predominante em cada um deles.

Analisaremos duas transcrições de improvisos de cada autor: de Pixinguinha, o do choro Pagão (1946) e Um a Zero (1947), e de K- Ximbinho, Sempre, Velhos Companheiros (1981) e Lá Vem a Baiana (1958).

Para a escolha destes improvisos, foram usados os seguintes critérios: de Pixinguinha, selecionamos dois choros gravados em 1947, com o flautista Benedito Lacerda. As gravações fazem parte de uma importante fase de sua carreira, quando passou a tocar ao saxofone seus famosos "contracantos" enquanto a flauta executava a melodia. Com a mudança de instrumento, seus improvisos, que antes eram feitos como variações melódicas ou pequenas alterações rítmicas da voz principal, passaram a ter uma função mais subordinada à harmonia, ou seja, de acompanhamento desta voz principal. Esses contracantos podem, de certo modo, ser considerados improvisações, pois não eram previamente escritos. Analisaremos melhor essa questão no capítulo referente à improvisação. 
Quanto à escolha dos choros de K-Ximbinho, selecionamos duas gravações de seu último disco lançado em 1981, Saudades de um clarinete, em que todas as faixas são de sua autoria, como também todos os arranjos e regência. Esse disco foi lançado no ano de seu falecimento, e acreditamos que nessa fase, seu estilo de improvisação já se encontrava consolidado e amadurecido. Os improvisos escolhidos fazem parte de uma certa fase na carreira de cada um deles sendo essa seleção intencional, para indicar melhor os estilos individuais, representando com clareza os modelos das construções de seus improvisos.

Nossa sugestão de análise restringe-se à improvisação dentro de um gênero definido, o choro; dentro de um território específico, que supõe suas delimitações e regras, citaremos Derek Bailey (1993) que, na introdução de seu livro, Improvisation - its nature and practice in music, caracteriza as duas principais formas de improvisação - a idiomática e a não idiomática:

Idiomatic improvisation, much the most widely used, is mainly concerned with the expression of an idiom - such as jazz, flamenco or baroque - and takes its identity and motivation from that idiom. Non idiomatic improvisation has other concerns and is most usually found in so-called 'free' improvisation and, while it can be highly stylised, is not usually tied to representing an idiomatic identity. ${ }^{4}$

No caso da nossa pesquisa destacaremos a improvisação idiomática, ou seja, dentro de um idioma definido.

Como subsídio para nossas análises, iremos examinar o conceito de improvisação vertical e horizontal citado pelo autor George Russell (2001), em seu livro The Lydian Cromatic Concept of Tonal Organization. Isso será feito com os exemplos de solos de jazz que vão ilustrar o que é uma improvisação que prioriza a harmonia - chamada de "improvisação vertical" - e outra que enfatiza a melodia, chamada de "improvisação horizontal".

\footnotetext{
${ }^{4} \mathrm{~A}$ improvisação idiomática se preocupa principalmente com a expressão de um idioma - como o jazz, a música flamenca ou barroca - e tem sua identidade e motivação originada desses idiomas. A improvisação não idiomática tem outra preocupação e é mais encontrada no que chamamos de livre improvisação, que não está atrelada a nenhuma identidade idiomática (tradução do autor).
} 
Os estudos acadêmicos mais sistemáticos sobre música popular no Brasil são ainda recentes, começaram na década de 1970 e nos últimos anos cresceram significativamente.

Na dissertação, Pesquisa Sobre Música Popular em São Paulo, Silvano Baia faz um levantamento bibliográfico sobre os estudos nesta área no Estado de São Paulo desde 1971 até 2001, em várias instituições de ensino. Podemos observar por meio desse trabalho um crescimento do número de dissertações e teses sobre esse campo nos últimos anos. Por exemplo: de 1971 a 1990 contamos com 30 trabalhos; de 1990 a 1999 temos 103; e de 2000 a 2004, no final desse levantamento, temos 125 dissertações. Notamos ainda que esses estudos são oriundos de várias áreas do conhecimento, tais como: História, Psicologia, Lingüística, Sociologia, além da Música. Outro dado interessante verificado no levantamento, é que a maioria das pesquisas em música popular enfatiza o estudo das canções, deixando a música instrumental dentro de um campo ainda pouco explorado. Além da música vocal, existem muitos estudos voltados à música folclórica realizados pela Etnomusicologia. A canção tem sido mais estudada do que a música instrumental, porque a primeira se utiliza de letras que proporcionam um rico campo de análise, tanto histórica como social. Sem as palavras, torna-se menos evidente a observação das inter-relações da música com o meio. Ela é um ponto de partida para a abordagem de aspectos sociais, políticos e culturais. Segundo Pahim (2002):

\begin{abstract}
A música popular é a expressão sonora de um contexto histórico, social, étnico, político e econômico. A partir do seu estudo podemos perceber toda uma série de relações, conflitos e influências presentes no processo de desenvolvimento das sociedades, na medida em que lida com temas e fatos cotidianos, mas também com o imaginário de um povo e seu processo de identidade. (p. 9)
\end{abstract}

Não há um consenso em relação ao conceito de música popular. Questão polêmica, já foi tema principal da $2^{\underline{a}}$ Conferência Internacional da IASPM, International Association for the Study of Popular Music. Dentro do vasto panorama de debates sobre o conceito de música popular, admitimos para esse trabalho que ela é uma manifestação cultural essencialmente urbana, consolidada no século XX, com a expansão das cidades. Para sermos mais específicos, acompanhamos a perspectiva de Napolitano (2002) que afirma: 
Aquilo que hoje chamamos de música popular, em seu sentido amplo, e, particularmente, o que chamamos "canção" é um produto do século XX. Ao menos sua forma "fonográfica", com seu padrão de 32 compassos, adaptada a um mercado urbano e intimamente ligada à busca de excitação corporal (música para dançar) e emocional (música para chorar, de dor ou de alegria...) [...] Sua gênese, no final do século XIX e início do século XX, está intimamente ligada à urbanização e ao surgimento das classes populares e médias urbanas. Esta nova estrutura socioeconômica, produto do capitalismo monopolista, fez com que o interesse por um tipo de música, intimamente ligado à vida cultural e ao lazer urbanos, aumentasse. A música popular se consolidou na forma de uma peça instrumental ou cantada, disseminada por um suporte escrito-gravado (partitura/fonograma) ou como parte de espetáculo de apelo popular, como a opereta e o musichall (e suas variáveis). (p.11-12)

Ainda sobre o conceito de música popular, Weffort (2002) diz:

O conceito de música popular é utilizado para designar a música urbana e designa uma categoria distinta da chamada música erudita. Sendo fácil reconhecer a necessidade de diferenciação, os conceitos com que se traçam esses contornos obrigam a, pelo menos, alguma reflexão. A delimitação dos conceitos de música popular e música erudita não é tarefa fácil. Uma das razões para essa dificuldade reside no fato de se procurar aquela diferenciação, sobretudo no produto «música» em vez de se colocar o enfoque na caracterização do processo «fazer música».(p.9)

O mesmo autor segue afirmando que a questão da relação entre a música popular e a música erudita tem sido objeto de polêmica com forte carga ideológica. A obra de Pedrosa, A Música Popular Brasileira Estilizada, faz uma compilação sobre essa polêmica:

\begin{abstract}
...sempre preconceituosamente se julgou a música popular como algo inferior tecnicamente, e por essa visão equivocada, uma parcela de valor da cultura popular foi perdida ou esquecida. Os profissionais da mpb afinal não podem ser considerados povo, nem burguesia, nem aristocracia. Simplesmente uma categoria profissional que produz algo consumido às vezes por todas as classes: de acordo com o produto existe uma maior ou menor aceitação nesta ou naquela esfera social.(p10)
\end{abstract}

Essa investigação abordará a música popular destinada ao mercado, isto é, produzida, divulgada e veiculada por meios de comunicação de massa e por isso não podemos separá-la da indústria fonográfica - uma vez que elas sempre andaram juntas e se influenciaram mutuamente. Quando falamos da importância da indústria fonográfica, referimo-nos às gravações, fonte principal de nossa pesquisa. No caso do Brasil, as primeiras gravações datam do começo do século XX. Somente 
a partir daí poderemos avaliar a produção da música popular, uma vez que antes delas não havia gravações, existiam apenas citações em textos escritos, o que impossibilita um estudo mais apropriado do nosso tema.

Como vimos anteriormente, no Brasil existem poucos trabalhos sobre música popular instrumental, e quando se trata do campo da improvisação, os números são ainda menores. Uma das prováveis causas da escassez é a falta da partitura escrita (recurso mais utilizado em análises musicais) dentro dos improvisos.

Nossa principal fonte de estudo para o presente trabalho se constitui nas gravações, que serão transcritas e posteriormente analisadas. Em muitos casos, a transcrição dos solos não é suficiente para a compreensão ampla da obra, sendo necessário que nos reportemos à própria gravação, em que poderemos ouvir as sonoridades específicas do instrumentista, suas inflexões, o tipo de interpretação que sugeriu e em que contexto se deu o improviso. Segundo Derek Bailey (1993), a transcrição está longe de ser uma ajuda para entender um improviso e sim desvia a atenção para considerações secundárias. Em realidade, poucas são as descrições técnicas, e quase todos os músicos preferem termos abstratos para discutir improvisação. Apesar de não ser o ideal para a análise de improvisos, esta será uma das fontes que utilizaremos, juntamente com as gravações. Vale lembrar que o objetivo do pesquisador em música é tentar achar o sentido dentro da obra, que vai além das simples notações, partituras e o que elas podem revelar, percebendo as várias partes que compõem a estrutura total, identificando pontos de reflexão, a fim de encontrar o método mais eficiente de análise em cada caso específico.

Napolitano (2002) complementa:

\footnotetext{
O grande desafio de todo pesquisador em música popular é mapear as camadas de sentido embutidas numa obra musical, bem como suas formas de inserção na sociedade e na história, evitando, ao mesmo tempo as simplificações e mecanicismos analíticos que podem deturpar a natureza polissêmica e complexa de qualquer documento de natureza estética. (p.7778)
}

Em relação ao improviso, o pesquisador deve levar em conta que a atuação do músico está comprometida com o meio do qual ele faz parte, naquele momento. As interações com o grupo são preponderantes quando falamos de música improvisada. Quando refletimos sobre o significado dessas criações "instantâneas", 
entramos em uma forte discussão que nos leva ao próprio significado da música. Consideramos de grande importância uma análise cuidadosa que considere o momento em que aconteceu o improviso, as conversas musicais do grupo, as "trocas" com a platéia, apesar disso por se tratar de uma dissertação, iremos nos limitar estritamente às questões musicais.

Sobre a questão do significado, Cook $(1987$, p.9) argumenta que ao invés de falar sobre significado como algo que a música possui, deveríamos falar disso como "algo que a música produz [...] em um determinado contexto".

Em música popular, e mais ainda na música improvisada, o performer, ou o músico tem muita liberdade em relação à partitura. Segundo Napolitano (2002), tanto a estrutura quanto a performance são igualmente importantes, mas uma não deve ser reduzida à outra.

\section{Resumo dos capítulos:}

A dissertação está estruturada em 2 partes principais. Na primeira parte serão examinados alguns conceitos sobre improvisação de um modo geral, e esclarecidos fatos referentes ao contexto em que a pesquisa está inserida, o choro. A segunda parte será dedicada aos compositores e à análise de suas obras.

O capítulo 1 tem como tema principal a improvisação. Inicia-se com definições do termo, e como esse procedimento foi praticado em várias épocas da história da música, tanto erudita quanto popular. Traçaremos em linhas gerais um panorama e o grau de valorização desta prática através dos tempos. Na segunda parte do capítulo, trataremos da questão da análise de improvisos e suas dificuldades. Examinaremos alguns comentários sobre a expressão análise musical e seus conceitos, a problemática da análise de improvisos, e a dificuldade em encontrar uma metodologia eficiente para essas análises.

$\mathrm{Na}$ parte final do capítulo definiremos os termos "improvisação vertical" e "improvisação horizontal", tema amplamente estudado por Russell (2001). Serão apresentados exemplos que serão importantes para compreensão das análises posteriores. 
O capítulo 2 será totalmente dedicado ao choro, gênero no qual se desenvolve nossa pesquisa. No início apresentaremos um pequeno panorama desde o nascimento do gênero, bem como as possíveis origens e significados do termo choro, as primeiras gravações e obras de referência. Depois passaremos à improvisação no choro: as divergências a respeito dessa questão expressadas nas idéias dos estudiosos do tema; o ambiente descontraído do choro e a liberdade de interpretação dos músicos; a tradição oral como essência da transmissão da memória do choro; a prática dos músicos tocarem "de ouvido" e o impasse dessa liberdade dentro dos estúdios de gravação; e por fim, a indústria fonográfica como agente limitador dessa liberdade.

O final do capítulo trata da função dos instrumentos do grupo de choro, e da "baixaria" - procedimento usado desde as origens do choro - como importante influência na caracterização do gênero. Ainda nesse capítulo, como exemplo dessas linhas, faremos uma transcrição de um contracanto encontrado nas primeiras gravações realizadas no Brasil no início do século XX.

O capítulo 3 inicia-se com uma pequena apresentação de Pixinguinha seguida das análises das obras escolhidas.

A biografia de Pixinguinha já foi muito estudada e o material fonográfico disponível hoje em dia é vasto. As informações contidas nessa apresentação foram retiradas de duas importantes obras: a de Sergio Cabral (Pixinguinha: vida e obra) e a de Marília Silva Barboza e Oliveira Filho (Pixinguinha - filho de Ogum Bexiguento). Como referências sonoras consultamos a obra Casa Edison e seu Tempo e com base nessas gravações podemos dividir a carreira de Pixinguinha em fases. Os dois improvisos que vamos analisar, Um a Zero e Pagão, fazem parte de uma fase importante de sua carreira quando passou a tocar saxofone, imprimindo um estilo característico em suas criações, com influências das tradições mais antigas do choro.

No capítulo 4 investigaremos a vida e a obra de K- Ximbinho, tendo como foco o papel da improvisação em sua obra.

Faremos alguns comentários sobre suas inovações na forma estrutural do choro, que antes eram construídos em três partes, passando a ter apenas duas, abrindo um espaço para a improvisação. A influência do jazz e das "Bigbands" em 
suas composições e improvisos. A importância de Severino Araújo e a Orquestra Tabajara, local em que trabalhou a maior parte de sua vida, as orquestras de baile e as casas noturnas em que trabalhou.

Apesar das poucas gravações que tivemos acesso, traçaremos um perfil de sua prática como intérprete-improvisador. Outro ponto importante é identificar dentro de sua obra, o encontro entre a musicalidade brasileira e a norte americana, o diálogo entre elas que percebemos tanto nas suas composições quanto nas improvisações. Seguiremos com as análises de seus choros Velhos Companheiros, Sempre e Lá vem a Baiana. 


\section{CAPÍTULO I}

\section{IMPROVISAÇÃO}

\section{1 - Definições}

Improviso é uma palavra originária do latim improvisus, significa o inesperado, o repentino, o que não foi previsto ou preparado; na área musical, improviso é a composição criada pelos intérpretes, em plena execução da peça. Na improvisação, o intérprete pode se manifestar mais livremente, pois ao se executar uma obra que não tem forma definitiva, o músico torna-se uma espécie de intérprete-criador, podendo a cada execução criar algo diferente e particular, unindo a sua criatividade à do compositor, se houver um.

A improvisação sempre esteve presente na música tanto erudita quanto popular, em todas as épocas em maior ou menor grau, e sua importância varia dependendo da época, do estilo ou da cultura onde se encontra. Em virtude das dificuldades intrínsecas que apresenta como tema de pesquisa acadêmica, a improvisação tem sido pouco estudada e acreditamos que a maior dificuldade talvez seja a falta de uma partitura escrita que, em tese, poderia ser considerada o objeto da análise musical. A transcrição de uma improvisação não capta elementos fundamentais da performance cuja característica principal é a ação/pensamento em tempo real. A partitura só nos revela parte destes elementos geralmente relacionados às alturas e durações dos sons. A improvisação não necessita necessariamente da escrita musical e pode mesmo prescindir desta. Para se analisar um improviso é necessário ampliar os parâmetros (performance e integração entre os músicos, e o momento em si do evento musical em questão), buscando outros métodos além dos usualmente utilizados e aplicados.

Bruno Nettl (1964, apud Cliffkormann, 2004) define o termo improvisação da seguinte maneira:

A criação de uma obra musical, ou a forma final de uma obra musical, no momento em que ela está sendo feita... até certo ponto toda atuação envolve elementos de improvisação, embora o grau possa variar dependendo da época e lugar, e até certo ponto toda improvisação é baseada numa série de convenções e regras implícitas. Por causa da 
própria natureza - improvisação é essencialmente evanescente - é um dos assuntos menos receptivos à pesquisa histórica. (p.3)

Ainda Nettl (1974), em artigo intitulado "Thought on improvisation a comparative aproach", propõe novos conceitos sobre a improvisação e a composição, não como processos opostos, mas contínuos, apenas separados por graus de espontaneidade. Segundo Nettl uma mostra deste conceito pode ser encontrada ao estudarmos, por exemplo, músicos como Schubert que criam numa grande velocidade e desenvolvem o tipo que ele chama de composição rápida; e por outro lado, músicos como Beethoven poderiam ser classificados como compositores que se utilizam da técnica de composição lenta, uma vez que suas obras eram muitas vezes reescritas até que ele as considerasse acabadas. Esta idéia mostra claramente como é tênue a barreira que separa composição e improvisação.

Nesses termos, a composição poderia ser uma improvisação em que o autor a antecipa, colocando-a na partitura, que pode ser imutável, ou em alguns casos oferecer relativa liberdade de expressão; por sua vez, a improvisação seria uma composição onde o autor (ou autores se a improvisação for coletiva) cria em tempo real, sem nada antecipar, deixando que a música se revele no momento da execução - e neste caso, é possível observar algumas regras estabelecidas que proporcionam ao intérprete maior ou menor grau de liberdade nesta criação instantânea.

A partir desta idéia apresentada por Nettl (1974), passaremos a examinar brevemente a história da música a fim de analisar o papel desempenhado pela improvisação.

Conforme o dicionário Grove de Música (1994), a arte musical ocidental engloba um bom número de formas de improvisação. Na música eclesiástica antiga, a improvisação se fez presente em vários momentos: os cantores na música antiga aprendiam como acrescentar uma nova linha a um canto litúrgico quando este era executado; os primeiros exemplos de organum ou motetos escritos mostram sinais de suas origens improvisatórias. Para um melhor entendimento de como a improvisação nesta época se fazia presente, vamos traçar um paralelo entre a arquitetura e a música. De acordo com Fonterrada (2003), até o séc. XIII e XIV, o 
edifício gótico se construía continuamente, assim como os contrapontos se desenvolviam horizontalmente:

Entre os pilares consonantes, as linhas melódicas desenvolvem-se horizontalmente, do mesmo modo que a narrativa ou a catedral. Um exemplo deste comportamento gótico é a "composição aditiva", comum àquela época, em que as vozes se relacionam com o tenor (de tenere sustentar), em termos de consonância e dissonância, mas independem umas das outras. Nesse tipo de composição, pode se acrescentar ou omitir vozes sem que a estrutura se altere substancialmente. (p. 33/34)

Ainda de acordo com Fonterrada (2003), no Renascimento, os contrapontos eram condicionados por princípios harmônicos, e tinham uma resultante vertical de base acordal, curvando-se à eufonia.

No Renascimento e no Barroco, a improvisação continuou a ser utilizada quando os cantores improvisavam sobre um cantus firmus e os instrumentistas no baixo contínuo ${ }^{5}$. Os compositores da época do Barroco (final do séc. XVII e séc XVIII) ofereciam grande liberdade aos intérpretes, talvez como uma reação à complexidade dos contrapontos renascentistas.

A ornamentação, também considerada como forma de improvisação, persistiu nos séculos XVIII e XIX e ocupou uma importante posição, por exemplo, na ópera italiana. Encontramos também improvisação nas cadências dos concertos, nas fugas de Bach e Haendel, nas variações de Mozart e Beethoven, na escola francesa de órgão do final do séc. XIX e início do séc. $X X^{6}$

Também são encontrados improvisos na música clássica indiana, árabe, japonesa e flamenca, como também nas músicas populares do mundo todo. Não é nossa intenção nos deter no tema da improvisação nessas culturas, o intuito deste pequeno trecho foi apenas demonstrar a importância da improvisação no decorrer dos séculos permeando várias culturas.

\footnotetext{
${ }^{5}$ Neste tipo de improvisação o executante partia de uma cifra - o baixo cifrado - e realizava de forma relativamente livre os acordes que esta cifra indicava. A liberdade do tecladista se restringia à forma de tocar - arpejada, em bloco, espalhada, compactada etc. - e a eventuais ornamentações e criações de fragmentos melódicos em contraponto com a melodia do instrumento solista ou cantor.

${ }^{6}$ Dicionário Grove de música, RJ: Zahar, 1985.
} 
Nosso objeto de estudo nesse trabalho se refere ao campo da música popular, e dentro deste universo, o jazz é um dos tipos de manifestação musical onde a improvisação ocupa lugar de destaque. Segundo Carlos Calado (1990):

Improvisação é um termo que quase se confunde com o jazz - sendo que jazz significa, em boa parte, música improvisada, criada no momento. Dentro dele, a música escrita é como um pretexto para uma nova criação e o intérprete possui uma grande liberdade na execução. (p.41)

O desenvolvimento da improvisação no jazz alcançou um grau tão elevado, que como nos lembra Fabris (2006), tornou-se tão ou mais importante do que os elementos harmônicos e melódicos do tema sobre os quais se improvisam. Corroborando a afirmação de Fabris, notamos que em arranjos para uma formação musical do tipo bigband, mesmo sem considerar a improvisação, a individualidade dos instrumentistas se faz presente e este diferencial proporcionado pela marca pessoal do músico acaba ganhando relevo.

As improvisações no jazz quase sempre seguem um tema exposto no início, seguido de improviso tendo como base a seqüência harmônica do tema exposto, para ser reapresentado no final. Ainda que haja outros modos de improvisação, este é o modelo mais usual e predomina nos meios jazzísticos.

$\mathrm{Na}$ história do jazz foram poucas as mudanças neste formato até o séc. $\mathrm{XX}$, mas nota-se que o aumento na complexidade da harmonia colaborou em grande parte para que os improvisos ganhassem maior liberdade melódica e harmônica. Nos anos 1950/60, surgiu o free jazz, estilo onde as improvisações eram mais livres e já não seguiam o formato que mencionamos acima - tema-improviso-tema. Esta vertente do jazz entre outras coisas trabalhava com uma harmonia atonal, não se prendendo ao tema nem a fraseados convencionais e muitas vezes com ênfase na textura e na sonoridade.

O tipo de improvisação que examinamos até aqui pode ser chamada de "improvisação idiomática", e como dissemos na introdução, foi definida por Derek Bailey (1993) como uma improvisação inserida dentro de um território delimitado. Do outro lado existe o que chamamos de "improvisação livre", também denominada "improvisação não idiomática", ou seja, uma improvisação que não ocorre dentro de um território específico. Isto não significa que esta prática não dialogue com os 
idiomas, pois os músicos são inevitavelmente ligados a eles. Assim, a improvisação livre seria uma espécie de prática trans-idiomática não subordinada a nenhum idioma específico.

Segundo Rogério Costa "numa performance de improvisação livre, a conversa entre os improvisadores se apóia muito mais na materialidade dinâmica do som do que na idéia de comunicação e o conseqüente estabelecimento de significados e gramáticas abstratas" ${ }^{7}$ que se encontram nas práticas idiomáticas.

Como já foi afirmado, a investigação do nosso trabalho se refere à improvisação no contexto da música popular, mais especificamente do choro, por isso não nos deteremos em observações sobre a improvisação não idiomática.

Como a análise de improvisos, que é a essência do nosso tema, é um assunto ainda pouco estudado, nos deparamos com alguns problemas quanto à escolha do método mais eficiente e qual a melhor abordagem em termos de análise. Abordaremos essa questão na próxima parte.

\section{2 - Análise de improvisos}

Antes de abordarmos a dificuldade de se analisar improvisos, iremos mostrar algumas definições e comentários sobre o tema análise musical.

Na edição de 1994 do Grove Dicionary, Bent define o termo análise musical como um processo de composição de uma estrutura musical nos seus elementos constitutivos mais simples e a investigação sobre esses elementos no interior dessa estrutura.

$\mathrm{Na}$ introdução de seu livro sobre este mesmo assunto Cook (1987, p.2) diz ser difícil imaginar que exista um método analítico que não questione os seguintes temas - sobre divisão em seções, sobre a importância de diferentes conexões, e sobre a influência do contexto onde a obra está inserida. A despeito desta unidade de objetivo, os vários métodos de análise são freqüentemente estudados

\footnotetext{
${ }^{7}$ Extraído do texto - O instrumento musical enquanto extensão da voz no contexto da livre improvisação. (texto não publicado, utilizado durante o curso Os Territórios da Improvisação: Pensamento e Ação Musical em Tempo Real s/d.).
} 
isoladamente um dos outros, e o que é pior, com rivalidades entre eles. Cook faz ainda uma crítica aos analistas que utilizam a peça musical para provar a validade de seus métodos, em outras palavras, quando estão mais interessados em legitimar teorias do que na sua aplicabilidade prática. $O$ autor segue afirmando a importância da combinação de diferentes técnicas de análise, ou seja, os métodos de análise devem ser complementares e não excludentes. No seu livro Analysis Through Composition, Cook (1996) afirma que a análise está muito afastada da prática, que os estudantes têm uma abordagem muito cerebral e a vêem desvinculada da experiência prática da música.

A maneira correta de se analisar uma obra musical sempre foi assunto discutível entre os estudiosos do tema. Bent (2001, vol I), reflete sobre esta questão:

\begin{abstract}
"Mas, como em todo material artístico, a música apresenta um problema inerente à natureza desse material. A música não é tangível e nem mensurável como um líquido ou um sólido para análise química. $O$ objeto da análise musical tem de ser determinado. Ele será a própria partitura, ou a imagem sonora que a partitura projeta, ou a imagem sonora na mente do compositor no momento da composição, ou uma performance interpretativa, ou uma experiência temporal do ouvinte [...] Não há unanimidade entre os analistas sobre qual seria mais correto, mas a partitura (quando disponível) fornece um ponto de referência de onde 0 analista parte em direção a uma ou outra imagem sonora" (p. 528-529).
\end{abstract}

O tema da análise musical, como nos lembra Bent, está longe de atingir a unidade de opiniões, e sempre haverá questões que serão levantadas e indicadas como relevantes a serem desenvolvidas.

No decorrer da história da música erudita ocidental pode-se perceber a busca por precisão e controle através de uma escrita cada vez mais detalhada, já na música popular, nem tudo está registrado na partitura. Muitas delas estão escritas somente com as cifras do acompanhamento ou melodias cifradas. Outras nem são escritas.

Os estudos analíticos referentes à música popular são recentes, principalmente quando se trata de improvisação, como dissemos anteriormente, acreditamos que isto se deva ao fato de que um dos principais recursos utilizado em pesquisas na área musical esteja concentrado essencialmente na análise da partitura escrita, e dentro do universo da música popular podemos observar que esta não possui o mesmo valor que na música erudita. 
Para compreendermos essa questão e relacioná-la ao nosso assunto, observamos que sempre foi uma prática comum no choro executar as músicas de cor. Isso de maneira alguma significa que esses músicos não sabiam ler partituras, a grande maioria deles vinha de bandas militares, ambiente em que era necessário a leitura musical. O que as gravações nos revelam é que nessa prática de execução sempre existiu grande liberdade na hora da interpretação: as músicas nunca eram tocadas da mesma maneira, ora se modificam as melodias (floreios, apojaturas, mordentes, etc), ora os ritmos (atrasando ou adiantando), ou as articulações (ligados, stacattos). Isto nos faz concluir que na música popular a partitura funciona como uma espécie de ponto de partida, e o músico possui certo grau de liberdade no momento da sua performance. Sobre essa liberdade de interpretação, Fabris (2006) assinala:

\begin{abstract}
Esta constatação também reforça a idéia de que, diferentemente do que ocorre na música erudita, a música popular permite uma aproximação muito maior entre o processo criativo e o processo de interpretação, diminuindo a distância entre o compositor e o intérprete. O texto notado em forma de partitura pelo compositor popular prevê e deixa espaços que serão preenchidos pelas singularidades, cultura e desejos musicais do intérprete, ao mesmo tempo em que as suas práticas de performance, intrínsecas ao processo de transmissão oral do conhecimento musical nos gêneros populares, inspiram a escrita de seus compositores. (p.26)
\end{abstract}

Acreditamos que a solução para a análise de um improviso seja primeiramente sua transcrição a partir de uma gravação (mesmo sabendo que dificilmente conseguiremos obter uma descrição fiel do momento), e posteriormente, para complementação das análises, examinar as próprias gravações que transcrevemos a fim de observar fatores como: inflexões de frases, variação timbrística, articulações etc.

No prefácio do seu livro Early jazz (1968, p.x), Gunther Schüller afirma que explicação verbal e exemplos musicais escritos nunca são substitutos para a música em si. Se isso é verdade para a música "clássica" mais ainda para o jazz, que é feito basicamente de música improvisada, que desafia a notação. Notamos que neste caso o recurso de uma partitura é praticamente impossível e se existir é irrelevante. Para este mesmo autor, apesar da limitação da notação musical, uma partitura de Schöenberg ou Beethoven, por exemplo, é um documento definitivo, como um mapa do qual se originam algumas interpretações ligeiramente diferentes; por outro lado uma gravação de uma improvisação é algo único e em alguns casos a única versão 
que podemos chamar de "definitiva" de uma coisa que nunca quis ser definitiva; e conclui que a única coisa disponível para o historiador do jazz é a gravação. Tendo em vista a importância da gravação no contexto da improvisação, nossas análises das transcrições estarão sempre relacionadas às suas gravações para completarmos ao máximo o entendimento das mesmas. Schüller vai um pouco além nessa problemática quando afirma que uma página de uma partitura escrita é antes de tudo, um objeto concreto; e pode ser estudado como um quadro; no entanto uma performance musical, mesmo que tenha sido gravada, só existe naquele momento. A música está sempre em movimento e não pode ser congelada no tempo.

Pelos motivos anteriormente comentados, encontramos no decorrer deste trabalho algumas dificuldades em selecionar um método que seja eficiente para a análise de improvisos, ou seja, que nos permita caracterizar com clareza os dois estilos de improvisação que nos propomos analisar nesta dissertação. Como não encontramos um método ideal para a análise de improvisos achamos adequado combinarmos algumas técnicas de análise e adicionarmos as respectivas gravações para ampliar o entendimento das observações.

Segundo Dahlhaus (1997): quando a música é subtraída do seu contexto, aspectos como novidade, genuinidade, epigonismo, deixam de existir, e tais critérios são bases para um julgamento estético. Sabemos que a nossa perspectiva não leva em conta aspectos contextuais, porém acreditamos que para os nossos propósitos a idéia de nos limitarmos às transcrições de solos, partituras originais e gravações se constitui a abordagem mais adequada.

Nosso intenção é que a análise sirva para iluminar a música e não para provar a realidade dos métodos. Que ela não se torne uma disciplina independente da importância prática da performance musical, da composição ou da educação. O importante não é inventar novas técnicas, mas utilizar realmente as que já possuímos; e para torná-las úteis, devemos combiná-las. ${ }^{8}$

Nossas análises têm como objetivo principal a caracterização de dois caminhos que são tomados no decorrer das improvisações e a sua demonstração através dos dois compositores destacados. Denominaremos estes caminhos de vertical e horizontal, e iremos examiná-los a seguir.

\footnotetext{
${ }^{8}$ Cf..Cook, Nicholas (1987).
} 


\section{3 - Abordagem Horizontal e Vertical}

Para nos auxiliar em nosso tema de estudo nessa dissertação, a análise de improvisações dentro do choro brasileiro, citaremos a importante obra de Russell (2001) - The Lydian chromatic concept of tonal organization, em que o autor observa dois caminhos básicos dentro da improvisação que chamamos de "idiomática". Segundo Russell, uma música pode ser comparada metaforicamente a uma viagem através de um rio, e no caso da improvisação o músico tem a possibilidade de fazer esta viagem de várias maneiras. Os dois principais modos desta "navegação" são denominados como o modo ou abordagem vertical e o outro que é chamado de horizontal.

O músico que navega por este rio pelo modo que chamamos vertical faz paradas em cada acorde, ou seja, constrói uma improvisação através da escala relativa a cada acorde. Uma improvisação neste nível, ou seja, vertical requer que o músico projete a identidade harmônica de cada acorde com a melodia, definindo os tipos de acorde na medida em que eles aparecem dentro da música. Para esta definição nota-se inicialmente uma construção baseada principalmente em terças e fundamentais dos acordes, e posteriormente, através da experimentação outras notas além das estruturais do acorde também podem ser incorporadas nos levando aos acordes extendidos ou alterados. Por exemplo: em um acorde de $\mathrm{C} 7$ pode-se adicionar um $\mathrm{Db}$ ou um $\mathrm{Gb}$, assim este acorde se transforma em $\mathrm{C7}$, b5,b9.

Criar uma melodia que se encaixe em cada acorde dentro da respectiva progressão é o principal objetivo deste nível "vertical". O improvisador vertical sugere o tipo de acorde através da melodia do seu improviso. Na gravitação vertical a melodia é indicada pelo acorde, ela é concentrada em cada acorde da progressão.

O outro modo de navegação por este rio é chamado de horizontal. Nesta abordagem, a melodia é construída não com paradas e definições sobre cada acorde, e sim baseada em uma escala relacionada a mais de um acorde, ou seja, ao centro tonal daquela progressão. O músico não precisa necessariamente definir cada acorde identificando-os um a um, mas utiliza escalas comuns a mais de um acorde. Este tipo de abordagem não faz parada como a vertical, em cada acorde e sim nos centros tonais. 
Quando encontramos uma única nota sustentada em mais de uma acorde, ou uma única escala utilizada através de vários compassos, podemos dizer que a melodia está baseada numa abordagem horizontal.

Notamos em cada improvisador uma tendência ou preferência por um desses tipos de abordagem, mas ambos os modos caminham lado a lado e durante 0 improviso observamos, nem sempre muito claramente, as passagens de um modo ao outro.

Antes de examinarmos os exemplos desses diferentes caminhos achamos relevante, a título de ilustração do tema, introduzir alguns conceitos sobre improvisação que Schüller (1986, p.57,58) faz em seu livro Early Jazz, e que se revelarão importantes na compreensão do que veremos adiante.

Schüller escreve que a improvisação de várias linhas simultâneas é um conceito típico encontrado em diversas tradições orais de várias regiões africanas, perpetuado sob várias formas desde os primórdios do jazz - música marcada pela improvisação coletiva. Com o advento dos arranjos (influência decididamente "branca", segundo o autor), e a incorporação do solo arranjado de outro modo, ou ao menos parcialmente pré-arranjado, esta multilinearidade do jazz foi aos poucos sendo abandonada (por volta dos anos 50 ). O conceito "africano" de justapor o solo com o grupo baseava-se principalmente em princípios de repetição e não em variação que, segundo Schüller, seria um conceito da música espanhola. Alguns estudiosos dizem que houve influência da música espanhola nos Estados Unidos, especialmente da música flamenca, opinião esta que o autor refuta completamente, pois acredita que as concepções estruturais da música espanhola e africana são tão diferentes que seria muito difícil ter existido alguma assimilação. Ambas possuem improvisação, mas com caráter completamente diferente: a técnica da improvisação espanhola tem como principal característica a elaboração e a ornamentação, uma espécie de adorno, podendo tornar mais complexa uma melodia simples; já na música africana inexiste esse senso de ornamentação, mas podemos encontrar o que chamamos de variações do material dado, utilizando-o de várias formas aumentado, diminuído, fragmentado, reagrupado.

As características observadas acima nos remetem a um paralelo com a horizontalidade e verticalidade dentro da improvisação. 
As observações do autor sobre a ornamentação encontrada nas improvisações espanholas nos chamam a atenção pela similaridade com as improvisações do choro, também baseada nessa característica, as quais já foram amplamente explicadas e ilustradas por diversos autores anteriormente. Em contrapartida, as características apontadas por Schuller como "africanas", pelo menos no que se refere à simultaneidade das linhas, nos remetem às baixarias do choro, justapondo-se à melodia, que depois vieram a influenciar um dos caminhos de improvisação no choro que estudaremos a seguir.

Baseados nos conceitos de horizontalidade e verticalidade na improvisação de Russell (2001), encontrados na pesquisa de Berton (2005), examinaremos dois exemplos dentro da música americana, isto certamente facilitará a compreensão em nossas análises posteriores.

Segundo Berton podemos definir uma abordagem horizontal (A.H.) quando, por exemplo: dentro de uma cadência típica da música popular, Dm - G7 - C7M (II V - I), o improvisador utiliza como material fonte a escala de Dó Maior sobre os três acordes, gravitando em um só centro.

Dentro desta abordagem utilizam-se mais padrões escalares.

\section{Exemplo 1}

Escala de G Blues

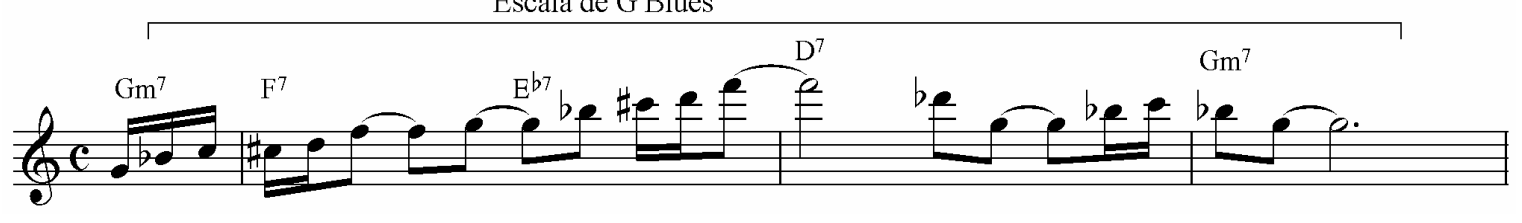

Joe Henderson -"Song of my father" - Exemplo de abordagem horizontal (p.72) 
Neste exemplo citado pelo autor, podemos ver a aplicação de uma escala blues $^{9}$ em "Sol", enquanto a progressão harmônica caminha, independentemente desta, gravitando no mesmo centro "Sol".

Dentro do universo do jazz selecionamos um compositor para exemplificar a abordagem horizontal - Paul Desmond ${ }^{10}$. Este grande saxofonista foi conhecido por sua sonoridade suave e por sua maneira melódica de tratar a improvisação.

Neste improviso podemos observar que a maioria das frases é formada por escalas e motivos melódicos, somente em poucos trechos encontramos uma abordagem vertical.

Ao final da dissertação colocaremos o improviso abaixo da linha do tema para que possamos observar as conexões entre o tema e o improviso.

Esta gravação foi realizada em 1975 no disco Pure Desmond (CBS) e tem como título l'm old fashioned (Jerome Kern). Iremos examinar apenas o primeiro "chorus" 11 do improviso por julgarmos suficiente para a caracterização da abordagem horizontal.

O solo se anuncia dois compassos antes do "chorus" propriamente dito, nesta preparação já encontramos o motivo inicial do seu solo, uma frase construída com intervalos de terças, como podemos ver no exemplo abaixo.

\section{Exemplo 2}

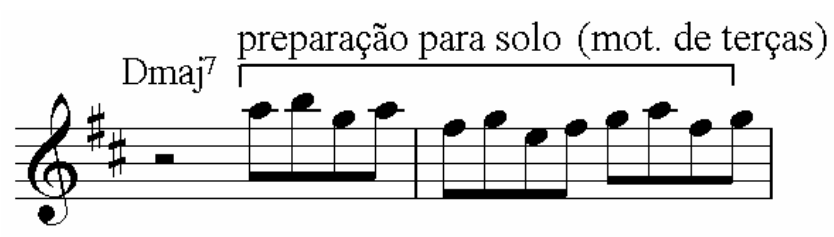

\footnotetext{
9 A escala blues é uma escala de seis notas e pode ser representada da seguinte forma: $1, \mathrm{~b} 3,4, \mathrm{~b} 5,5, \mathrm{~b} 7$.

${ }^{10}$ Paul Desmond - (1924 - 1977) - saxofonista e compositor norte-americano, integrante do quarteto de Dave Brubeck entre 1959 e 1967 e fez parte do West Coast Jazz; uma das suas composições mais conhecidas é Take Five.

${ }^{11}$ No jazz, chorus significa a estrutura harmônica do tema, a qual servirá como base para a improvisação. Quando o músico improvisa sobre uma repetição exata da forma do tema, quer dizer que ele está executando um chorus de improviso.
} 
Nos dois primeiros compassos do solo encontramos frases praticamente iguais, a segunda iniciando-se um tom abaixo da primeira - uma abordagem claramente horizontal, que valoriza mais a linha melódica do que os acordes relacionados a ela, D - Bm7 - Em7 - A7.

\section{Exemplo 3}

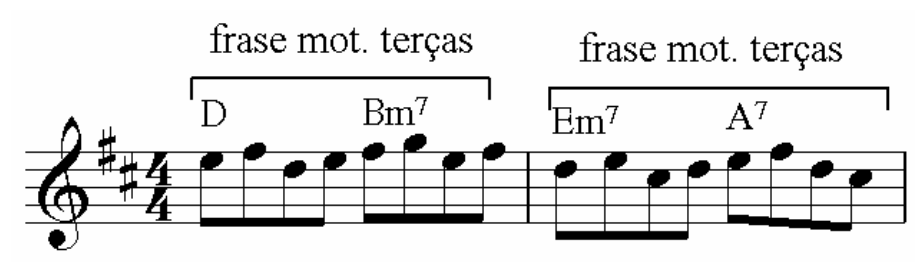

No exemplo 4 podemos dizer que o autor usou uma abordagem vertical (A.V.), isso porque nesses três compassos ele utiliza simplesmente notas do acorde em semínimas e mínimas, representadas por fundamentais, terças, quintas e sétimas.

\section{Exemplo 4}

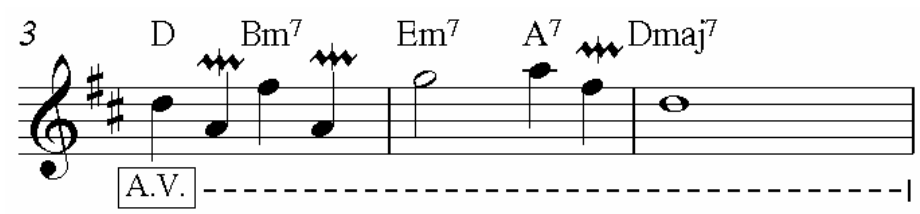

Seguindo para o compasso 6 , encontramos uma frase com aproximações cromáticas em $D$, que antecipa a terça menor $(F)$ do compasso seguinte.

Nos próximos compassos, o autor usa frases curtas, antecipando notas do próximo acorde; no compasso 7, o Sib (sétima de C), e no compasso 8, o Fa (fundamental de F). Neste caso, percebemos uma maior preocupação com o aspecto motívico da frase. 


\section{Exemplo 5}

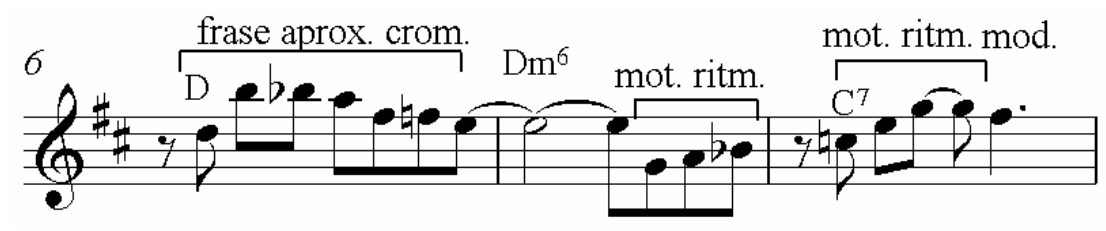

No exemplo 6 encontramos dois compassos com os mesmos motivos melódicos - $7^{\underline{a}}$ e $5^{\underline{a}}$ ascendente - independente da mudança dos acordes de Fm7 para E7. Aqui o autor deixa evidente a tendência para a horizontalidade em seu solo, com repetição de motivos iguais em compassos com harmonias diferentes.

\section{Exemplo 6}

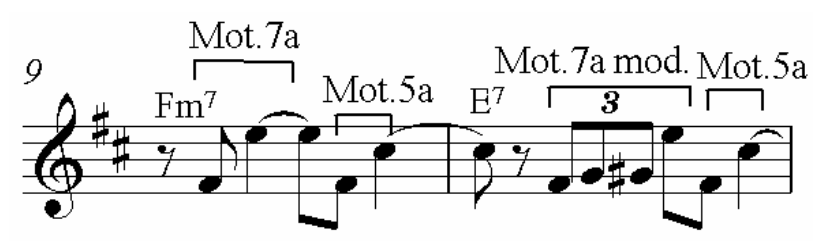

No compasso 11 e 12 observamos uma característica de verticalidade, aqui encontramos praticamente um encadeamento de arpejos - Bm7 e E7. No compasso 13 - mesmo motivo de terças. No compasso 14 - uma antecipação do A7. No compasso 15 - uma frase cromática ascendente alcançando o $\mathrm{Si}$, e descendo exatamente como o tema sobe nos próximos dois tempos; o autor usa esta subida do tema com uma frase modificada, como indicamos no exemplo a seguir. 


\section{Exemplo 7}

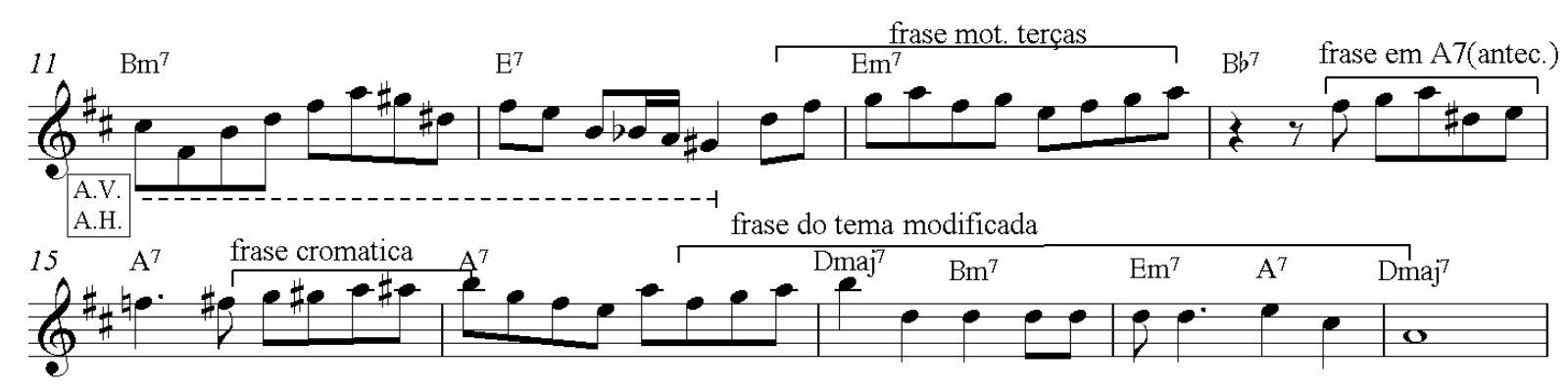

Esse exemplo de Paul Desmond demonstra claramente sua preferência pelas construções horizontais. Essa tendência pode ser notada na maioria de seus improvisos. Contrapondo-se a esse tipo de construção, seguiremos agora com o conceito de abordagem vertical.

Voltando às definições de Berton (baseados em Russell), uma abordagem vertical (A.V.) seria quando o improvisador, dentro desta mesma cadência, utiliza-se de três centros de gravitação, correspondentes às três fundamentais de acordes envolvidas. Em Dm7, ele pensa no segundo modo de Do (dórico), no G7, pensa no quinto modo de Do (mixolídio), e em C7M, no primeiro modo de Do (jônico).

Dentro desta abordagem usam-se mais arpejos.

\section{Exemplo 8}

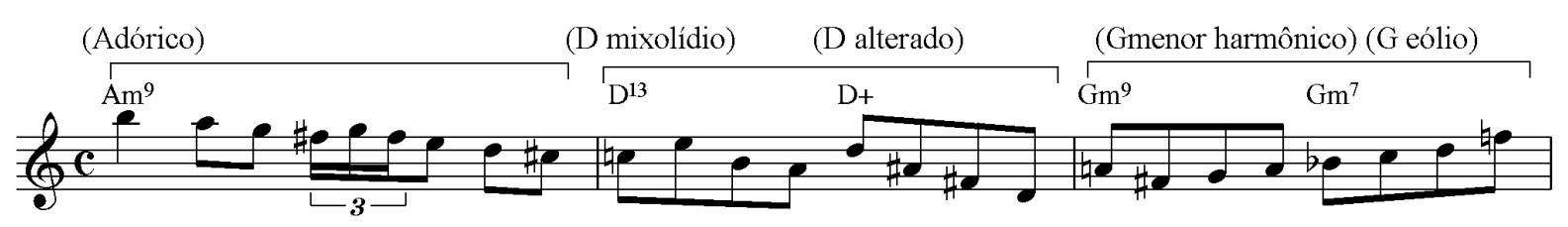

Abordagem Vertical (Jamey Aebersold) (p. 73)

Notamos nesse exemplo, que a melodia sugere os acordes dados na cifra; tanto as nonas dos acordes Am9 e Gm9, quanto a décima terceira, a quinta aumentada, e a sétima dos acordes D13, D+ e Gm7, estão na melodia. Notamos também que, para cada acorde, há uma escala diatônica referente a ele. 
Destacamos aqui a presença desta abordagem, com mais arpejos que padrões escalares.

Para ilustrarmos a improvisação vertical, selecionamos um improviso de John Coltrane $^{12}$, outro renomado saxofonista do jazz. Observa-se neste solo uma clara tendência à verticalidade.

"Giant Steps" é um tema em andamento muito rápido e a maioria dos compassos com dois acordes. Tornou-se um dos improvisos mais famosos de Coltrane, revelando grande domínio técnico do instrumento. O tratamento dado pelo autor é sempre através de modelos que definem bem o acorde. Nota-se menos preocupações com rítmicas diferenciadas ou motivos melódicos marcantes que se repetem em compassos diferentes, como vimos anteriormente no improviso de Paul Desmond.

Neste caso, analisaremos também os primeiros dezesseis compassos do solo, que julgamos o necessário para demonstrar o caráter vertical deste improviso.

Logo no compasso 2 encontramos uma tríade de C\#, seguida de um padrão muito utilizado por J. Coltrane, que se compõe de $1-2-3-5^{13}$, neste caso, Mi - Fa\# Sol\# - Si.

Na seqüência encontraremos tríades e padrões principalmente de arpejos.

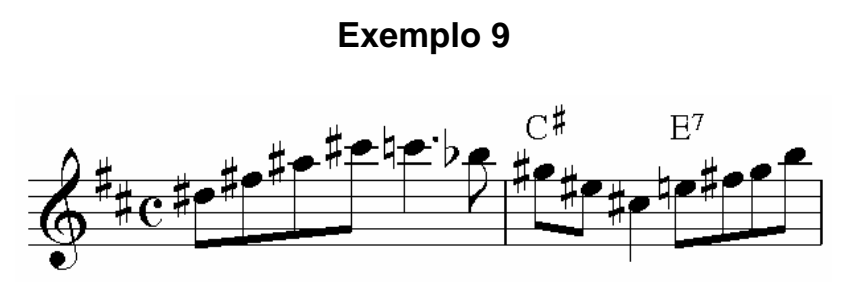

Não achamos necessário analisarmos compasso por compasso, porque nestes compassos iniciais o autor só utiliza a abordagem vertical. Mesmo nos compassos 4 e 12, onde encontramos respectivamente uma escala de $F$ maior

\footnotetext{
12 John Coltrane (1926/1967) - Saxofonista e compositor de jazz norte-americano, considerado pela crítica especializada como o maior sax tenor do jazz e um dos maiores jazzistas e compositores deste gênero de todos os tempos.

${ }^{13}$ Os números se referem ao intervalo formado com a fundamental do acorde.
} 
ascendente e de A descendente e ascendente, podemos considerar uma abordagem vertical, pois há uma escala para cada acorde.

\section{Exemplo 10}
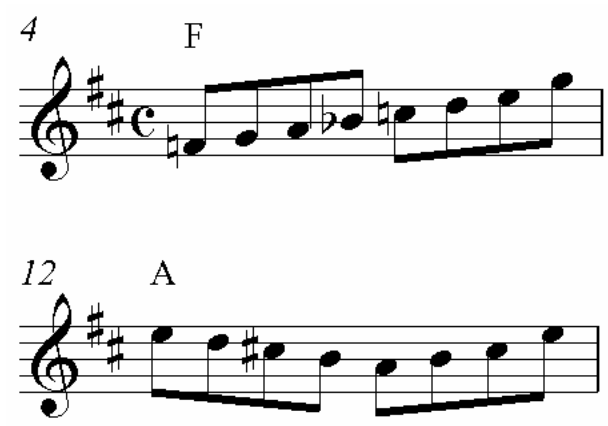

Encontramos alguns cromatismos que estarão marcados na partitura por $\mathrm{Cr}$ nos compassos $9,10,14$ e 15 .

\section{Exemplo 11}
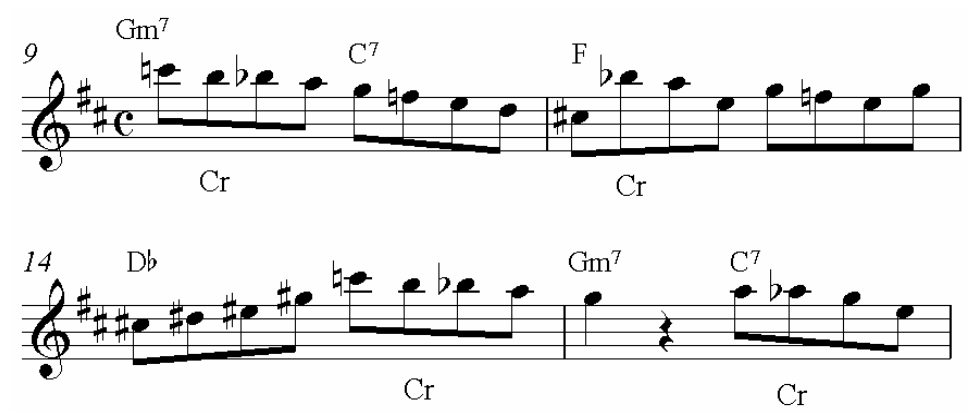

O autor também usa acordes "extendidos", ou seja, com a 9ª . Na partitura marcamos somente as que estão em tempos fortes. As outras serão consideradas como notas de passagem - como as que estão nos compassos 3, 10 e 13. 
Exemplo 12
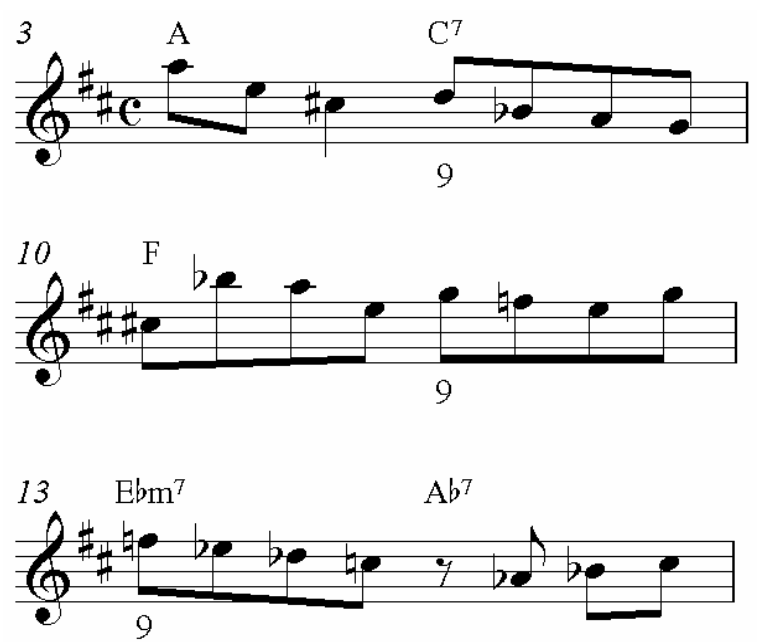

O aspecto rítmico é praticamente constante, sempre com colcheias, com exceção dos compassos 8, 13,15 e 16, lugar que se faz necessário uma respiração, considerando que o instrumento que apresenta o solo é um instrumento de sopro.

\section{Exemplo 13}
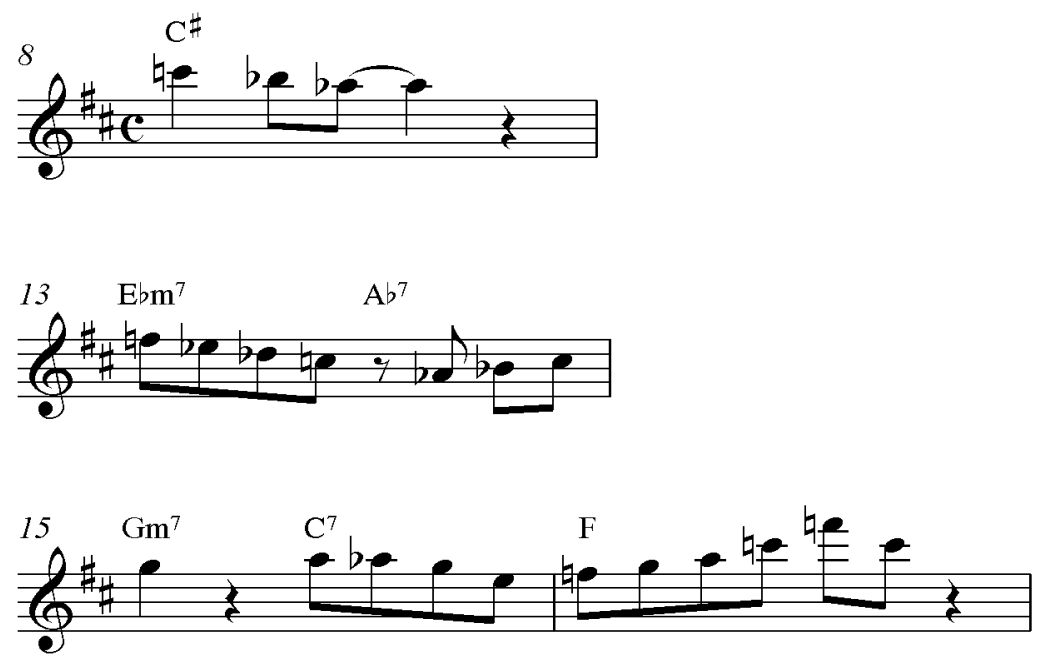

Escolhemos Paul Desmond e John Coltrane por considerá-los expoentes do jazz com características bem marcantes de horizontalidade e verticalidade, o que os torna exemplos interessantes para nossa pesquisa. 
Encontramos na dissertação de Berton (2001), um importante gráfico de comparação dessas abordagens, agora com exemplos de outros músicos de jazz.

\section{Exemplo 14}

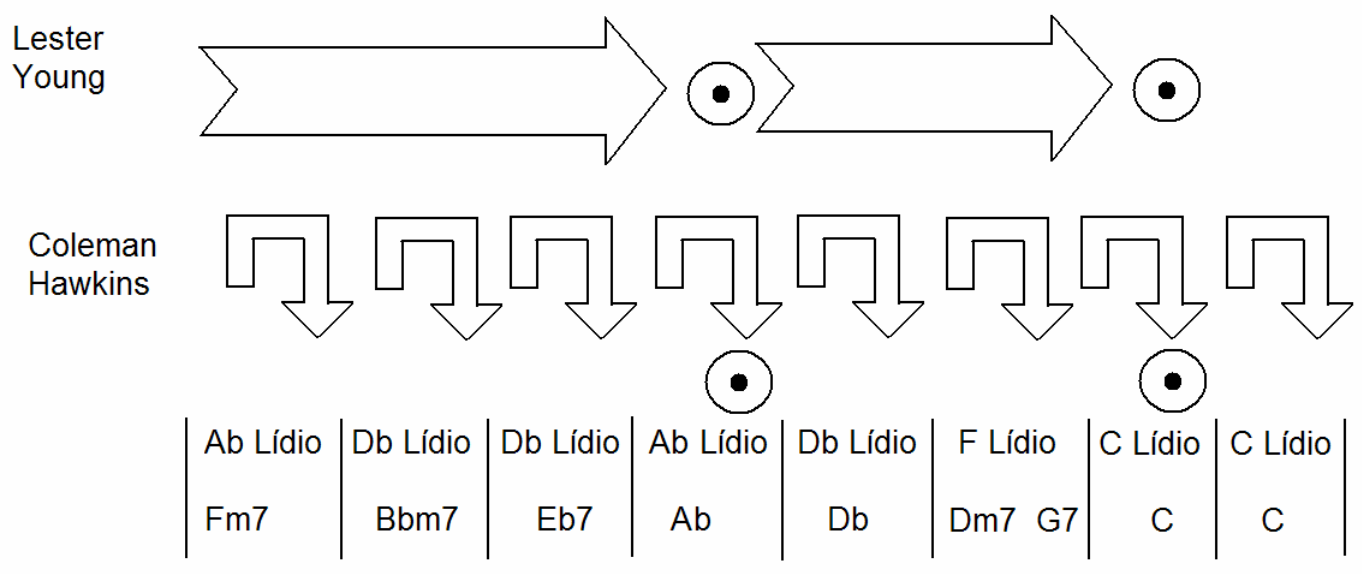

Gráfico comparativo de improvisação vertical e horizontal (p. 31)

Em uma tonalidade de Lá bemol (no exemplo, os oito primeiros compassos do tema "All the Things You Are" - Jerome Kern e Oscar Hammerstein), o músico Coleman Halkins - um músico que possui tendências de verticalidade - elaboraria a sua improvisação sobre os acordes dados pela harmonia (indicado pelas setas em curva), e Lester Young improvisaria sobre os centros tonais sugeridos por essa cadência (indicado pelos círculos), "desconsiderando" os acordes dados pela cifra, o movimento sugerido são as setas para a direita, o que podemos chamar de uma improvisação horizontal.

Nessa seção definimos e ilustramos as abordagens horizontais e verticais, através de exemplos de solos do repertório do jazz.

Como mencionamos anteriormente, o jazz sempre foi um gênero essencialmente ligado à improvisação, desde sua origem até os dias de hoje. $O$ material de pesquisa em relação à improvisação - livros, métodos, vídeos - referemse em sua maior parte ao jazz. Como nossa pesquisa se refere ao choro, 
encontramos alguma dificuldade em encontrar estudos que tenham a improvisação brasileira como tema.

No próximo capítulo examinaremos especificamente o choro, gênero dentro do qual estão inseridos os músicos escolhidos para nossa pesquisa. 


\section{CAPÍTULO II}

\section{CHORO: UM GÊNERO BRASILEIRO}

A grande maioria dos pesquisadores em música popular concorda que 0 choro pode ser considerado a primeira música urbana tipicamente brasileira.

Neste capítulo iniciaremos um pequeno exame dos caminhos percorridos por este gênero, com o objetivo de iluminar o tema e nos ajudar a contextualizar e apreciar criticamente nossos estudos posteriores.

\section{1 - Nascimento do gênero}

A época provável para o nascimento do choro situa-se entre o último quartel do século XIX e o primeiro do século XX, data que varia dependendo do autor.

Entre os pesquisadores não há consenso quanto à origem e significado do termo choro. Pinto (1978) afirma que choro não era propriamente um gênero da música popular, mas uma maneira de tocar, e também o nome que davam às festas em que se reuniam os pequenos conjuntos de flauta, violão e cavaquinho; Renato Almeida diz que choro é o nome dado a certos bailaricos populares, e José Ramos Tinhorão (1974, p.95) relaciona o choro com uma forma melancólica de executar as baixarias no violão. Temos também a definição de Ary Vasconcelos que atribui a origem da palavra choro a uma possível abreviação de "Choromeleiros", uma corporação de músicos com importante atuação no período colonial brasileiro. Siqueira (1970) escreve que a palavra choro poderia ter sido originada da palavra chorus em latim, que significa coro ou conjunto vocal. Para confirmar sua hipótese o autor cita o catálogo da Casa Edison de 1920 em que a expressão chorus aparecia para nomear pequenos conjuntos que gravavam neste mesmo lugar no começo do século. Câmara Cascudo (1967) em seu Dicionário de Folclore escreve uma possível origem da palavra: 
expressão que, por confusão com a parônima portuguesa, passou a dizerse xoro e, chegando à cidade, foi grafada choro, com ch. (p.208)

Podemos concluir que são variadas as opiniões sobre a origem da palavra choro, seu significado e suas primeiras manifestações musicais.

Weffort (2002) afirma que grande parte da historiografia da música popular referente a esta época é composta de obras com poucos dados concretos, a bibliografia disponível se limita a representações da memória com dados em regra geral escassos e a maior parte dos textos são expressões de opinião, testemunhos, ou relatos sobre testemunhos, não baseados em fontes primárias.

A produção historiográfica a respeito do choro só se apresenta muito tempo depois do seu surgimento. Choro - Reminiscências dos Chorões Antigos de Alexandre Gonçalves Pinto (1978) é um livro composto por mais de 300 pequenas biografias e notícias sobre músicos e compositores, tanto profissionais quanto amadores, desde 1870 até aproximadamente 1920. É considerada a primeira importante obra de referência do gênero e foi editada muito tempo depois dos fatos que procura abordar. Segundo Tinhorão (1997, p.111) um dos motivos da importância deste livro é que revela a condição social dos chorões. Eles eram funcionários públicos, soldados de polícia, feitores de obras, empregados do comércio e burocratas. Considera-se que os primeiros grupos de choro eram formados por integrantes das bandas de corporação, que saiam a tocar nas festas de igreja como também de pequenos conjuntos formados por conhecidos de bairro ou colegas de repartição que se apresentavam em festas particulares. Os melhores músicos do início do século fizeram fama nessas festas onde corria "de boca a boca" a notícia de seu virtuosismo até firmar-se o seu conceito de grandes instrumentistas.

Weffort vê no choro uma semelhança com o que Dahlhaus chamou de "música trivial" ${ }^{14}$, isto é, a música de entretenimento praticada no século XIX. Em ambas reconhecem-se elementos como sentimentalismo, a padronização tonal (embora mais desenvolta que o mero recurso às funções de tônica e dominante) e a forte presença do elemento acórdico na construção dos motivos melódicos do choro. Podemos imaginar que o choro do final do século XIX foi fortemente marcado pelos

\footnotetext{
${ }^{14}$ No século XIX, afirma Dahlhaus, a chamada "música trivial" era caracterizada pela presença paradoxal de sentimentalismo e mecanização. As melodias eram, regra geral, pouco mais que
} 
ideais estéticos e procedimentos musicais da época, sendo que estes não são necessariamente brasileiros.

Nosso estudo terá início no começo do século XX, época em que surgiram as primeiras gravações, estas são essenciais como fontes para este trabalho. Qualquer tentativa de pesquisa nessa área antes desta data teria que lidar com as dificuldades relacionadas à carência de registros e documentos. Apesar das gravações serem consideradas retratos fiéis da sonoridade das músicas da época, sempre devemos analisar com cautela, uma vez que elas apresentam restrições sonoras. As técnicas de gravação desta época eram bastante limitadas. Uma dessas limitações é que não havia boa captação dos sons graves, o que dificultava a escuta da linha do baixo. Outro sério problema era o espaço físico das salas onde eram realizadas as gravações que não comportavam grandes formações; além disso, os precários equipamentos de gravação pioravam ainda mais este cenário ${ }^{15}$. Além da falta de recursos técnicos, devemos considerar que o custo da gravação era muito alto, o que afetava e muito a escolha do material a ser gravado.

Sabemos da importância das gravações como fonte primordial de análises, mas devemos levar em conta que vários fatores influenciaram na seleção desses registros sonoros. Weffort comenta que a coleção de registros disponibilizados reflete critérios de escolha onde entram fatores de ordem comercial, técnica e estética.

Francheschi (2002, p.118) observa que nos primeiros exemplos de gravação da fase mecânica havia uma preferência por instrumentos de sopro e cordas no lugar do piano que passou a ser considerado um instrumento inadequado pela limitada faixa de registro de freqüência na gravação. A sonoridade da gravação dos metais era de melhor qualidade do que a dos cantores acompanhados por piano, flautas, violão e cavaquinho. Nesta época o Rio de Janeiro possuía o maior e mais numeroso conjunto de bandas militares do Brasil, e a mais importante foi sem dúvida a do Corpo de Bombeiros.

paráfrases de acordes reduzidas a duas funções harmônicas: tônica e dominante (apud Weffort, $p$. 12).

15. O estúdio da Casa Edison era localizado nos fundos de uma loja da rua do Ouvidor 105, com aproximadamente $5 \mathrm{~m}$. de largura por menos do dobro de comprimento, e não permitia mais do que 8 a 12 figuras.(Francheschi, p.118) 
Os primeiros registros sonoros do repertório do choro foram realizados pela Banda do Corpo de Bombeiros do Rio de Janeiro, comandada por Anacleto de Medeiros $^{16}$ (Cazes, 1998).

Tinhorão (1976, p.99) comenta que o aparecimento desta instituição coincide com o advento das gravações em disco, e isto permitiu que esses grupamentos musicais (bandas militares) com predominância de instrumentos de sopro dessem a sua contribuição definitiva à música popular, através das gravações dos mais diferentes gêneros criados ou nacionalizados pela ação dos conjuntos de choro durante a segunda metade do século XIX.

A Banda do Corpo de Bombeiros do Rio de Janeiro foi a primeira a ter registro em disco e nestas gravações ouvimos sempre a versão reduzida do grupo, já que a formação completa não caberia no estúdio da Casa Edison. Esses registros são documentos sonoros importantes e imprimem um retrato da música brasileira do início do século XX.

Nesse pequeno histórico procuramos contextualizar os primeiros momentos do surgimento do choro e os primeiros registros em disco. Passamos agora a analisar especificamente a improvisação no choro.

\section{2 - A improvisação no choro}

Existe muita divergência a respeito da improvisação no choro; alguns autores entendem que ela é elemento inerente à linguagem deste gênero, enquanto outros defendem que não é parte essencial. Como não existiam gravações até 1902, é muito difícil avaliar como se desenvolvia a improvisação nessa época inicial, pois todos dados que temos são sempre controversos. Podemos encontrar na obra $A$ Casa Edison e seu Tempo (2002), um importante material de estudo e análise sobre o período que vai desde 1902, com as gravações da Banda do Corpo de Bombeiros do Rio de Janeiro, até os clássicos Carinhoso e Lamentos gravados em 1941 com Pixinguinha e seu conjunto. Quando ouvimos estes registros raramente observamos

\footnotetext{
${ }^{16}$ Anacleto de Medeiros (1866-1907) era funcionário da Imprensa Nacional, e foi o primeiro mestre da Banda do Corpo de Bombeiros, fundada em 15 de novembro de 1896 pelo próprio. Era também um orquestrador competente, e tocava qualquer instrumento, preferindo, porém, o saxofone (PINTO, 1936, p.40).
} 
improvisações, e quanto a essa complexa questão encontramos diversas opiniões. No prefácio do livro de Henrique Cazes: Choro, do quintal ao municipal (1998) Hermano Vianna ressalta que até as primeiras décadas do século $X X$, o improviso era um elemento inexistente na totalidade das gravações de choro.

Nesta mesma obra (1998) o próprio autor escreve:

Uma audição atenta das gravações de choro da fase mecânica surpreende por aspectos como a quase total falta de improvisação. Muitas vezes a mesma parte de uma música é repetida quatro ou cinco vezes sem nenhuma alteração. Só dá para sentir o calor da improvisação quando toca o Pixinguinha, com ele tudo é mais vivo, mais alegre, mais rítmico. (p.45)

Esta mesma visão é compartilhada por Franceschi (2000), quando afirma que:

O que se escreveu, mitificando a criatividade de interpretação do choro, não está registrado nas gravações, nem da primeira e nem de boa parte da segunda década do século XX. Talvez razões comerciais não permitissem arriscar as ceras com possíveis erros ou com questionamentos nas execuções; ou, até mesmo, por disciplina, os músicos fossem obrigados a executar o que estava na pauta, sem se permitirem qualquer improviso. 0 que está gravado, salvo raras exceções, é repetitivo e sem nenhuma criatividade de interpretação, apesar de sua indiscutível qualidade musical. As primeiras manifestações de que algo novo estava ocorrendo, em interpretação, foram dadas pelo Choro Carioca, em 1914. Mas só em 1919, nas primeiras gravações individuais de Pixinguinha é que vemos despontar o que sempre se louvou como interpretação criativa do choro, desde as últimas décadas do séc. $\mathrm{XIX}$ e nas duas primeiras do século $\mathrm{XX}$, mas que em disco ninguém ouvira. (p.138)

Contrapondo-se aos autores supracitados, alguns consideram que o choro é um gênero essencialmente de improvisação, como por exemplo, esta citação no livro de Cazes:

É importante lembrar que o choro traz consigo o mesmo elemento que permitiu ao jazz atingir seu grande desenvolvimento: a improvisação. Esta é sua grande força. (Maestro Lindolfo Gaya na carta "A propósito do choro", 1977, apud Cazes, 1998)

Numa opinião que fica entre as duas vertentes citadas sobre improvisação no choro, Fabris (2006) ressalta sua existência, porém com limites: 
No choro, os temas geralmente apresentam grande invenção melódica e harmônica e, por isso, a improvisação geralmente acontece mais ao nível da variação melódica, da sugestão de alteração da métrica, da realização rítmica com sutilezas que parecem escapar das possibilidades da notação e que imprime o assim chamado "molho" do choro. (p.13)

Essa diversidade de opiniões não se limita aos estudiosos, teóricos e todos que escreveram sobre música popular. Os próprios músicos não revelavam muita clareza sobre o assunto. Em um depoimento a Caldi (2001), Dino Sete Cordas ${ }^{17}$, músico que participou das célebres gravações de Pixinguinha com Benedito Lacerda, afirmou que não havia partes escritas nas seções das gravações, era tudo improvisado. Já Pixinguinha tinha outro conceito do significado de improvisação, e em depoimento ao $\mathrm{MIS}^{18}$, defendeu que seu conjunto era ensaiado e não tocava na base do improviso, o que nos leva a deduzir que a expressão "de improviso" para ele significava "sem ensaio".

Acreditamos que a falta de improvisação encontrada nas gravações não era necessariamente o que acontecia nas rodas de choro. Talvez seja precipitado afirmar que o choro era tocado da mesma maneira nos dois lugares, uma vez que nas rodas existia mais liberdade e não havia o limite do tempo dos estúdios de gravação; além disso, a descontração do ambiente - geralmente familiar e aberto tanto a amadores quanto a profissionais favorecia a improvisação. Paulo Loureiro de Sá (1999, p.62) cita um exemplo que se enquadra nessa questão. Em diferentes gravações de "Noites Cariocas", Jacob do Bandolim interpreta de duas maneiras distintas; na primeira em 1993, realizada informalmente em sua casa numa roda de choro ele improvisa diversas vezes, já na outra de 1994, em estúdio, praticamente nenhuma. Isso reforça a hipótese de haver diferenças na forma de interpretação do choro dependendo do ambiente em que é executado.

Sobre este assunto, Weffort (2002) argumenta:

A sugestão, baseada na ausência de situações de improviso assinalada por H. Cazes na sua observação dos primeiros registros discográficos, aponta para dois problemas que merecem ponderação. Em primeiro lugar, o da

\footnotetext{
${ }^{17}$ Horondino José da Silva, conhecido como Dino 7 Cordas, (Rio de Janeiro, 5 de maio de 1918 Rio de Janeiro, 27 de maio de 2006) foi um violonista brasileiro reconhecido como maior influência do violão de 7 cordas, instrumento musical no qual desenvolveu sua linguagem e técnica. Foi também um dos maiores instrumentistas de choro.

${ }^{18}$ Série depoimentos: Pixinguinha. Rio de Janeiro, Museu da Imagem e do Som, 1997.
} 
delimitação do conceito de «improvisação»; em segundo lugar, o de saber se a «inexistência da improvisação» nas gravações discográficas permite a extensão dessa constatação às rodas de Choro, isto é, saber se o choro realizado na roda pode ser aferido pelos mesmos parâmetros que o choro gravado. A constatação de uma correlação não autoriza, por si, 0 estabelecimento de uma relação causal. (p.24)

Além da questão das diferenças quanto à liberdade de interpretação do músico de choro dependendo do lugar onde atuava, podemos observar outro importante parâmetro na comparação das performances destes instrumentistas: o público ao qual se dirigia. Tinhorão (1978) observa que a audiência definia mudanças na forma de execução das músicas, ou seja, quando a música era tocada em solenidades oficiais sua interpretação era diferente de quando tocada em bailes; isto fica evidente na análise das diferentes interpretações dos grupos de chorões:

\begin{abstract}
Quando esses conjuntos de choro eram chamados a tocar em casas de família respeitáveis (embora modestas), as polcas, valsas e mazurcas ainda soavam com uma certa contenção, muito próximas da execução que tinham à vista das partituras, nos salões onde imperavam os pianos. Se, porém, o mesmo grupo tocava em bailes de algum clube popular ou em casas de porta e janela da gente mais heterogênea da Cidade Nova, aí a interpretação tinha que ser diferente. (p. 62)
\end{abstract}

Concluímos que a existência ou não da improvisação no choro possui diversas causas, principalmente o local onde é executado e a audiência. Alem disso, não podemos desconsiderar a falta de uma clara compreensão quanto à existência de graus de liberdade dentro da improvisação. Nas gravações observamos interpretações mais livres, ou seja, algumas pequenas mudanças no fraseado, articulação ou embelezamentos melódicos, ou seja, um pequeno grau de improvisação, muitas vezes avaliado de forma diferente dependendo do historiador/autor.

A tradição oral sempre foi a essência da música popular do começo do século $\mathrm{XX}$, e essa tradição se estendeu através do tempo, pois sem o registro em partituras, os músicos tocavam de memória. Sempre foi uma prática comum ao músico tocar de "ouvido", ou seja, sem o auxílio de uma partitura.

O escritor Lima Barreto (1956), em um de seus romances descreve esta característica da seguinte maneira:

São mais apreciados os que tocam de "ouvido" e parece que eles põem nas 'fiorituras', trinados e mordentes, com que urdem as composições suas e 
dos outros, um pouco do imponderável, do vago, do instinto que há naquelas almas. (p.83)

Quanto a essa prática, Alves (1995) escreve:

Um levantamento feito recentemente com inúmeros músicos de choro determina com clareza o perfil de seus instrumentistas: músicos com extrema sensibilidade, com ouvido privilegiado e que, na maioria dos casos, não tiveram interesse ou acesso à teoria musical. Esses músicos guardam "de ouvido" um repertório incontável; são os arquivos vivos da música brasileira. (p.6)

Segundo Weffort (2002), em geral, o que acontecia na roda de choro se baseava na memória musical e a interação que ocorria entre os instrumentistas ficava muito próxima da "conversação". A imitação através da audição de discos possibilitava ao aprendiz buscar possíveis soluções para a reprodução de determinados temas, pois até pouco tempo atrás, a audição era praticamente o único recurso utilizado para a aprendizagem; a expressão "tocar de ouvido", que aponta para a capacidade auditiva do músico de choro, era algo de extrema importância para os músicos deste gênero.

O "tocar de ouvido" não é contrário à aprendizagem formal da música, embora muitos dos processos de ensino formal da música (sobretudo nos instrumentos de sopro) excluam ou limitem essa capacidade musical essencial que é a aplicação sistemática da memória na prática musical.

Aquilo que muitas vezes é visto de forma quase pejorativa na aprendizagem formal - tocar de ouvido - corresponde a uma qualidade fundamental de qualquer músico e o músico de Choro faz uso costumeiro dessa qualidade. Acontece também que o uso da memória implicado no «tocar de ouvido" abre caminho à outra qualidade, não menos importante: a aplicação sistemática do pensamento sobre o contexto tonal, na antecipação do movimento harmônico - uma forma de pensamento intrinsecamente musical, que se irá revelar na capacidade de improvisação. É o entendimento musical que permite a antecipação do sentido de transformação do contexto harmônico. É o entendimento musical que permite a improvisação. Contrastando com a valorização do adestramento mecânico, característica mais presente na didática da chamada música erudita, no Choro, a música se exercita e se pratica de forma mais próxima à da linguagem. (p.27)

Os músicos de choro aprendiam a "tocar de ouvido", as músicas se apresentavam nas rodas, e cada músico dependendo do seu grau técnico ou criativo, modificava um pouco a melodia ou o acompanhamento, colocando suas contribuições individuais. Em alguns casos, quando estas alterações eram muito apreciadas, acabavam se fixando à música e, a partir daí, fazendo parte dela. 
Sá (2000) observa:

No caso do choro não existe um improviso nascido de divagações, não se espera do músico chorão uma espécie de choro instantâneo, ele possui um referencial que será o seu limite. Os ornamentos são parte essencial do conteúdo improvisatório do choro. Isto quer dizer que a utilização de mordentes, glissandos, apogiaturas, grupetos, entre outros, se dá de forma imprevisível. E mais do que isto, estes ornamentos muitas vezes apresentam também um caráter diferente daquele observado na música erudita, pois fogem da precisão que a escrita musical pretende thes conferir. (p.69)

Nas gravações, podemos ouvir que tanto os acompanhantes quanto os solistas, dentro da sua linguagem possuíam certo grau de liberdade para modificar o ritmo e a melodia, ainda que com limitações. Se ao apresentarmos a música, não a reproduzimos exatamente, já temos aí um grau de improviso. Na prática, os grupos de choro faziam, e ainda fazem, uma improvisação coletiva, uma vez que todos improvisam - e ao mesmo tempo. Muitos desses músicos vinham da aprendizagem da música na prática, ouvindo e guardando a música na memória. Villa-Lobos ilustra bem essa prática:

Vem um e toca o tema, e vem o outro e improvisa. No saxofone, eu fazia assim, ó (e cantarolava). E vem o oficleide e toca um contraponto que é uma maravilha, bem superior a todos os contrapontos clássicos. Isto é o choro. É todo mundo tocando com seu coração, sua liberdade, sem regras, sem nada... a liberdade da arte (Aratanha, 1996, p. 12).

Jacob do Bandolim (1967) afirma:

Há dois tipos de chorões: há os chorões distantes, que eu repudio, que é aquele que bota o papel para tocar choro e deixa de ter, perde a sua característica principal que é a da improvisação, e há o chorão autêntico verdadeiro, aquele que pode decorar a música pelo papel, e depois lhe dar o colorido que bem entender, este me parece o verdadeiro, o autêntico, o honesto chorão. ${ }^{19}$

Até aqui examinamos os primeiros momentos do choro, o papel da improvisação neste gênero e a importância da memória, naquilo que chamamos de "tocar de ouvido", que oferece ao músico de choro uma grande liberdade dentro da interpretação. A seguir traçaremos um paralelo com o jazz, gênero em que a

\footnotetext{
${ }^{19}$ Série depoimentos: Jacob do Bandolim. Rio de Janeiro, Museu da Imagem e do Som, 24/02/1967.
} 
improvisação possui grande destaque, isto nos dará subsídios para um melhor entendimento do nosso tema.

Ao comparar a improvisação do choro e do jazz devemos também observar os aspectos composicionais de cada gênero para melhor compreender o contexto em que ocorre o improviso em cada um. No jazz, a improvisação desenvolveu-se a tal ponto que em alguns casos se tornou tão ou mais importante do que os elementos harmônicos ou melódicos do tema sobre os quais se improvisam.

Paulo Sá (2000) argumenta sobre as diferenças entre as improvisações do jazz e do choro:

\begin{abstract}
Os limites de caráter improvisatório entre o jazz e o choro começam no fato de que no jazz o pensamento do intérprete se concentra quase que exclusivamente no contexto das funções e dos encadeamentos harmônicos, que se apresentam ao músico como provedores de estímulos improvisatórios. O chorão por sua vez manifesta sua capacidade improvisadora fundamentada muito mais na melodia do choro que está interpretando, sendo a harmonia mais um decurso do que propriamente a idéia central ao redor da qual seria realizado um improviso.(p.67)
\end{abstract}

Em relação à forma, observamos que a maioria dos choros tradicionais possuem três partes com temas diferentes em tonalidades relacionadas (geralmente nos chamados tons vizinhos), geralmente com andamentos rápidos e de difícil execução. Quanto aos temas de jazz, observamos que geralmente são mais curtos e não possuem grande dificuldade técnica, deixando o solista mais à vontade em uma improvisação. A complexidade do tema no choro talvez seja uma importante característica da não improvisação neste gênero, ao contrário do que ocorre no jazz. Conforme assevera Sá (2000):

Outra diferença básica entre os dois tipos de improviso pode ser vista através da forma do jazz e do choro. Expor o tema, improvisá-lo tendo como base a idéia harmônica e em seguida finalizar expondo novamente o tema, é esta a forma daquele gênero musical norte americano, onde os temas são curtos e escritos para serem improvisados do início ao fim. Não é esta a proposta do choro.Sua forma, tradicionalmente ternária com cinco seções ABACA, não propicia o mesmo tipo de improviso realizado no jazz, isto é, o chorão não se propõe a expor um tema e depois improvisá-lo na íntegra. (p.67)

No choro, os temas geralmente apresentam grande invenção melódica e harmônica, por isso a improvisação quase sempre acontece ao nível da variação 
melódica, de alteração da métrica, da realização rítmica com sutilezas que parecem escapar das possibilidades da notação - o que imprime o assim chamado "molho" do choro. Paulo Sá (1999) continua:

... diz-se então, que está faltando "molho" quando certo choro é tocado de forma muito rígida, isto é, quando o intérprete toca exatamente o que está escrito na partitura. $\mathrm{O}$ "molho" se define muitas vezes através de uma mudança de métrica melódica, quando o chorão antecipa ou adianta uma nota ou um grupo de notas. . Isto significa que um choro pode ter seu "molho" sem ser improvisado.(p.68)

O mesmo autor (p.64) se refere a uma polêmica sobre a improvisação, tanto do jazz quanto do choro. Segundo ele, alguns estudiosos do assunto sustentam a hipótese de que a repetição dos esquemas modulatórios, baseados em escalas, se torna muito mecânica para os instrumentistas de jazz; e para o choro, de forma similar, as variações improvisadas que o chorão detém em sua memória e as aplica em momentos pré-determinados implicariam uma possível ausência de improviso.

Depois de analisarmos algumas das características da improvisação no choro e de compararmos em alguma extensão às do jazz, vamos estudar os papéis específicos que cada instrumento representa dentro de um grupo de choro.

\section{3 - A função dos instrumentos no grupo de choro e a "baixaria"}

A formação apresentada como sendo a primeira tradicional do choro, conhecida como "regional"20, é composta por flauta, violão e cavaquinho, podendo ser encontrado ainda o violão de sete cordas e o pandeiro. Existem também outras formações que contam com os instrumentos de cordas - o bandolim, o violão e o cavaquinho e os de instrumentos de sopro - além da flauta encontramos clarinetes, saxofones, oficleides, bombardinos, etc., além do piano.

Dentro do grupo do choro tradicional, existem os instrumentos solistas (que tocam a melodia), os acompanhadores (que fazem a harmonia) e os rítmicos. Em

\footnotetext{
${ }^{20}$ A generalização desse nome, provavelmente, originou-se na caracterização com roupas folclóricas, com que determinados grupos se apresentavam [no Rio de Janeiro], no final dos anos 20, dentre eles, os pernambucanos Turunas Pernambucanos,Turunas da Mauricéia e o carioca Grupo do Caxangá, com Pixinguinha.( Prata, Sérgio. A História dos Regionais. http://www.samba-choro.com.br).
} 
realidade, cada instrumento tem sua função específica dentro do grupo, e com isso, seus improvisos também têm funções e caráter diferentes.

Analisando melhor estas funções a que nos referimos, primeiramente temos 0 instrumento solista que executa a melodia e requer grande habilidade técnica do executante em virtude dos andamentos rápidos. Sendo assim, as improvisações dos instrumentos solistas geralmente são variações melódicas (ornamentos, apojeaturas, grupetos, trinados, etc). O instrumento acompanhador executa a harmonia. São vários os instrumentos com este papel, um deles é o violão de sete cordas, que tem a função de encadear os acordes desenhando a harmonia, deixando para o violão de seis, os acordes e as batidas. O violão de sete cordas é um instrumento muito importante em nossas análises, deixam transparecer com clareza as harmonias que estão por trás da melodia que tocam, as técnicas de acompanhamento desse instrumento foram cada vez mais se aprimorando, podendo chamá-las de improvisatórias. Mais adiante, quando estudarmos a "baixaria" ${ }^{21}$ do choro, traçaremos alguns comentários a respeito dele. Por último, existem os instrumentos rítmicos, que também podem ser considerados acompanhadores, mas para efeito didático classificaremos separadamente, não nos detendo sobre eles.

Para essa dissertação nos concentraremos na improvisação do instrumento solista e não em análises e considerações sobre os instrumentos de acompanhamento e rítmicos, ainda que estes no choro assumam um papel importante quando pensamos em improvisação.

Tanto nos grupos de choro quanto nas gravações das bandas do começo do Séc. XX podemos ouvir os instrumentos graves executarem linhas melódicas que exercem uma importante função estrutural dentro do gênero. Vamos agora examinar a influência deste procedimento no que se refere ao nosso tema.

O musicólogo Bruno Kiefer (1983) assim define o conceito de "baixaria":

O baixo contrapontístico e melódico, ou como classifica o baixo cantante, tão característico do choro, foi e é amplamente utilizado no maxixe e no samba. Funcionando como uma segunda melodia, a linha de baixo do choro, além de dialogar com a melodia principal define a harmonia conectando os acordes. É um tipo de linha muito ornamentada, com grande quantidade de notas, fazendo uso constante de semicolcheias e de tercinas, executada entre o C3 e o C1, e por isso soando bem em instrumentos que,

\footnotetext{
${ }^{21}$ No choro, o violão de 7 cordas caracteriza-se por executar frases de contraponto geralmente em escala descendente, utilizando-se somente as cordas graves, daí o nome baixaria.
} 
como o violão e o bombardino, possuem nos registros médio-graves a sua melhor sonoridade. Este tipo de linha ficou conhecido como "baixaria do choro", ou apenas "baixaria". (p. 15)

Em relação a baixaria no choro, uma questão interessante é saber se estas linhas executadas pelos instrumentos graves tiveram sua origem dentro das bandas militares do começo do século ou se foram as bandas que foram influenciadas pela linguagem dos violões.

Tinhorão (1998) afirma que as bandas foram influenciadas pelos violões:

\begin{abstract}
Musicalmente, segundo observou com propriedade o estudioso maestro Guerra-Peixe, o que se viria a conhecer por maxixe (e desde logo visto mais como forma de execução do que como gênero musical, a exemplo do que acontecia com o próprio choro) nada mais era do que a transposição para os instrumentos de registro grave das bandas - tuba, bombardino e trombone - do efeito da baixaria dos violões do choro, ou seja, o contracanto na parte grave do instrumento. (p.185).
\end{abstract}

Com outra perspectiva, Pinto (1978) diz que foram as bandas que influenciaram os músicos de choro, pois muitos deles eram integrantes destes grupos.

Franceschi (2000) faz uma citação de Guerra Peixe:

O maestro Guerra Peixe, com muita propriedade, afirmou que o maxixe estava estruturado na transferência da baixaria dos violões do choro para as notas graves dos instrumentos de sopro e, textualmente considerou: 'Era no Rio de Janeiro que os antigos chorões encontravam o melhor campo para as suas serenatas. Agrupamento instrumental, popular por excelência, o choro se caracterizava também, por aquela originalidade mestiça que o brasileiro introduziu na baixaria do violão (contracanto na parte grave do instrumento), desde a modinha até as polcas e, mais recentemente, os choros. Essa baixaria, tão em voga naqueles românticos tempos, teria feito sua incursão na música dos bailes públicos [...] os músicos das bandas tantas vezes os mesmos dos bailes públicos - certamente levariam para suas instrumentações, escritas ou improvisadas, esse processo urbano de contrapontar'( p.153).

Guerra Peixe (apud Franceschi, 2000) salienta que este costume era tão apreciado, que, às vezes, a melodia principal ficava no registro grave, e outros instrumentos mais agudos faziam o contraponto. E que não só a música de 
trombone, bombardino, oficlide, ${ }^{22}$ tuba etc. foi influenciada por estas aplicações dos baixos do violão, como também do piano, citando aqui a música de Ernesto Nazareth. Araújo (1972, p.26) diz em seu estudo sobre Nazareth, que ele condensou em suas composições os padrões rítmicos e melódicos do choro, da seresta e do maxixe. O processo mais importante para isso foi o de transpor para o piano, os instrumentos populares brasileiros: a flauta, o violão, o cavaquinho, o oficlide, 0 bombardino, a percussão.

O fato relevante é que esta forma de estruturação do baixo também é encontrada nas partes de bombardino das bandas militares e no baixo dos pianeiros da Primeira República. Carvalho (2006) escreve:

Através da análise das linhas de baixo do violão, do piano e dos sopros, percebe-se que do ponto de vista harmônico, o baixo no maxixe e no samba não difere das outras formas de estruturação das linhas dentro da música tonal, pois ele é estruturado basicamente através do uso de fundamentais e quintas, notas de aproximação e inversões. (p.73)

O mesmo autor afirma que, independente do instrumento utilizado, a baixaria é a mesma e não se pode afirmar em qual desses três instrumentos essa linha de baixo surgiu primeiro já que a falta de registros fonográficos não ajuda a resolver esta questão. Weffort escreve que os contracantos realizados nos instrumentos de sopro ou no violão de sete cordas levaram ao surgimento de uma textura polifônica que marca a sonoridade do choro enquanto gênero musical.

Para ilustrar o tema tratado acima, examinaremos um exemplo de Irineu de Almeida, gravado em 1911 com o grupo Choro Carioca.

Irineu de Almeida (1873-1916) foi professor de Pixinguinha e obteve destaque nas gravações do grupo Choro Carioca através da criação de contracantos. Esses contracantos - ou contrapontos, como eram chamados - são melodias que dialogam com a melodia principal, com uma função similar a baixaria dos violões, ou seja, tornar claro o caminho harmônico da música.

\footnotetext{
${ }^{22}$ Segundo Cazes (1998 p.47): "oficlide" (ou oficleide) era um instrumento barítono, constituído de um tubo vertical com chaves, de diâmetro maior que um fagote e soprado por um bocal de dimensões próximas ao de um trombone".
} 
A seguir, transcrevemos a música Massada (apenas a primeira e a segunda parte) de Irineu de Almeida ${ }^{23}$. Na gravação, o tema foi executado por Pixinguinha à flauta, e o contracanto por Irineu ao oficlide.

Nessa transcrição colocamos a melodia na voz superior e o contracanto abaixo. Nas repetições das seções era comum o intérprete variar suas frases em alguma extensão; colocamos algumas dessas variações para destacar a liberdade na criação desses contracantos. Em linhas gerais podemos notar que as características principais são: nos tempos fortes Irineu utiliza fundamentais, terças e sétimas, executando também alguns cromatismos, tríades e tétrades - que aqui denominamos arpejo.

${ }^{23}$ Transcrição feita pela autora através de CD anexo - parte integrante da obra Casa Edison e seu tempo. 

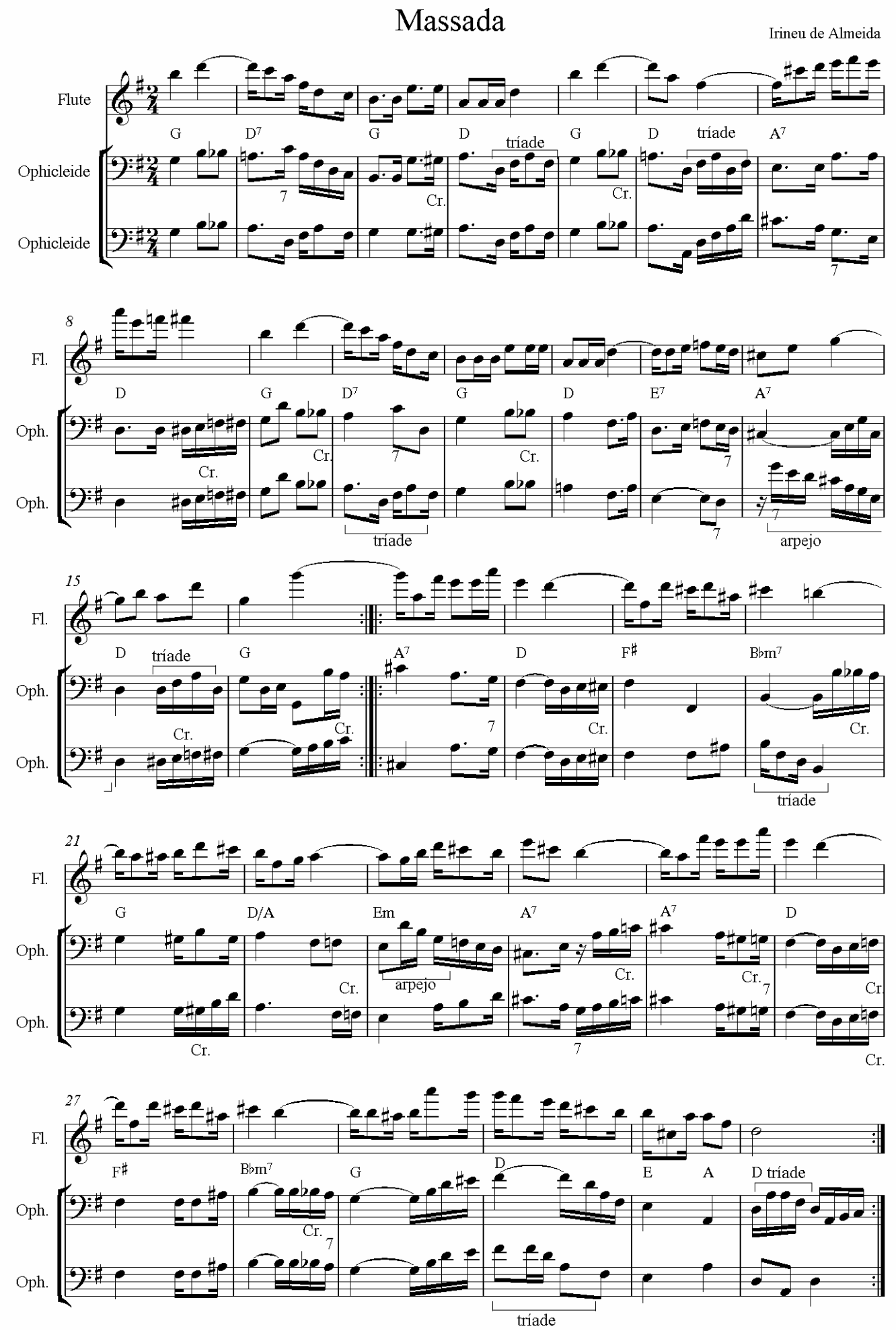


\section{CAPÍTULO III}

\section{PIXINGUINHA E A “MODERNA” TRADIÇÃO BRASILEIRA}

\section{1 - Apresentação ${ }^{24}$}

Alfredo da Rocha Viana Filho, o Pixinguinha, nasceu no Rio de Janeiro em 23 de abril de $1897^{25}$. Sua família era numerosa, e quase todos tocavam um instrumento. Seu pai, Alfredo da Rocha Viana, era funcionário dos telégrafos e seu nome figura na importante obra de Pinto, como melodioso flautista que tocava "de primeira vista". Grandes chorões da época freqüentavam sua casa em reuniões musicais, também chamada de "Pensão Viana".

Pixinguinha compôs sua primeira obra aos onze ou doze anos, o choro Lata de leite. Seu primeiro instrumento, que ganhou de presente de seu pai foi a flauta.

Seu grande incentivador, Irineu de Almeida, era um músico conceituado, componente da Banda do Corpo de Bombeiros do Rio de Janeiro e virtuose no bombardino e no oficlide. Irineu "Batina" ${ }^{26}$, vendo o rápido desenvolvimento de Pixinguinha, levou-o em 1911 para tocar na Orquestra Dançante e Carnavalesca Filhas da Jardineira. Neste mesmo ano Pixinguinha gravou as músicas São João debaixo dágua e Salve, ambas de Irineu, com o Grupo Choro Carioca. Em 1912 suas atividades de gravação aumentaram, e conta-se sua participação em 5 discos.

Pixinguinha tocava no carnaval, nas festas da igreja e em grupos que animavam festas. Seu primeiro emprego foi numa Casa de Chope ${ }^{27}$, convidado pelo seu irmão Otávio - o China. Assim, ele deixou definitivamente o Mosteiro de São

\footnotetext{
${ }^{24}$ Todas as informações sobre a vida de Pixinguinha incluídas nesse capítulo têm como referência duas obras importantes sobre o autor que são: CABRAL, Sérgio. Pixinguinha: Vida e obra. Rio de Janeiro: Lumiar Editora,1997 e SILVA, Marília Barboza da \& OLIVEIRA FILHO, Arthur L. de. Pixinguinha - filho de Ogum Bexiguento. Rio de Janeiro: Gryphus, 1998.

${ }^{25}$ Esse fato foi descoberto somente em 1968, por ocasião da comemoração de seu septuagésimo aniversário.

${ }^{26}$ Irineu de Almeida ganhou este apelido, pois usava uma casaca muito comprida, a qual se assemelhava a vestimenta de um padre.

${ }^{27}$ As casas de chope ou chopes cantantes, como eram chamadas, eram muito populares no Rio de Janeiro no fim do século XIX.
} 
Bento, onde estudava, e resolveu, com apoio de sua família, profissionalizar-se na música como instrumentista.

Freqüentava desde muito cedo as rodas de choro, mas nem sempre obedecia ao que estava escrito na partitura e, segundo ele mesmo, colocava umas bossas "por fora". Sua atividade como compositor começou cedo e, já em 1914, teve muito sucesso com a publicação do tango Dominante.

Desde 1917 já gravava várias obras de sua autoria. No ano de 1918 seu pai faleceu, mas Pixinguinha já estava encaminhado na profissão. No carnaval de 1919 fez grande sucesso com a música Já te digo.

Era muito comum, nesta época, encontrar orquestras que se apresentavam durante as projeções dos filmes mudos, e essa atividade rendia para Pixinguinha algum dinheiro. Mais tarde começou a tocar também nas salas de espera dos cinemas, lugar onde antes só havia música clássica ou popular importada. O gerente do Cine Palais, Isaac Frankel, o convidou para formar um conjunto que se apresentasse na sala de espera desse cinema. Assim nasceu o grupo que ganhou o nome de Oito Batutas, sugestão do próprio gerente. O repertório do grupo era composto de sambas, modinhas, polcas e canções sertanejas.

Foi em 1919 que aconteceu a estréia dos Oito Batutas no Cine Palais; eles se apresentavam com trajes sertanejos, e isso dava ao grupo uma forte conotação nacionalista e popular.

A música popular nunca havia sido apresentada nas salas de espera dos cinemas, pois essas eram espaços de entretenimento elitista e, como foi afirmado anteriormente, nesses espaços somente era tocada música clássica e internacional. Por ser uma grande novidade para a época, a presença da música popular nesses recintos foi alvo de muitas críticas. Almeida Bessa (cita um depoimento de Pixinguinha a João Batista Borges Pereira):

Havia duas orquestras em cada cinema: uma ficava junto da tela, musicando a fita, que era muda. Outra ficava na sala de entrada, alegrando os freqüentadores antes da fita começar. Artista preto só com muita paciência era aceito na orquestra de dentro. Assim, que nem ficar na cozinha, porque na sala de visita, na outra, de forma nenhuma.. (p.79).

Apesar de todas as censuras, o grupo fez sucesso e viajou pelo Norte e pelo Sul do país, ganhando projeção nacional. Voltaram ao Rio em 1920, permanecendo 
por mais alguns anos, com muito sucesso, no cenário musical carioca. O ponto alto na carreira dos Oito Batutas foi sua viagem à Paris, em 29 de Janeiro de 1922. Durante a estadia de Pixinguinha em Paris, quatro jazz bands se apresentavam na cidade. Através do convívio com os músicos americanos, nasceu em Pixinguinha a vontade de tocar saxofone, com isso Arnaldo Guinle mandou fazer um instrumento especialmente para ele. $\mathrm{O}$ saxofone foi então, pouco tempo depois, incorporado ao conjunto.

A viagem dos Oito Batutas para o exterior suscitou muitas polêmicas. Por causa da presença de quatro negros integrantes do conjunto - Pixinguinha, Donga, China e Nelson Alves - os críticos taxavam a viagem de desmoralizadora do Brasil, revelando assim o grande preconceito racial existente na sociedade carioca. Sobre essa questão, é importante ressaltar que desde a época que o grupo tocava no Cine Palais já eram alvo de comentários racistas.

Além da questão racial, diversas outras críticas foram feitas, principalmente com relação à incorporação de instrumentos de sopro no grupo, o que demonstraria uma grande influência do jazz-band americano. Porém o próprio Pixinguinha, em depoimento ao MIS, em 1966, declarou que diversos instrumentos de sopro já eram tocados pelos antigos chorões, inclusive o saxofone. Segundo ele, os críticos estavam mal informados quando atribuíam à influência do jazz a incorporação desses instrumentos.

Logo após o retorno de Paris, o grupo fez ainda uma excursão para a Argentina. Durante esta viagem surgiram grandes divergências entre os músicos, o que resultou no final do conjunto. Pouco tempo depois, em 1923, o grupo se reuniu novamente, com o nome de "Bi-Orquestra Os Batutas". Esse novo conjunto se apresentava tanto como um grupo de choro como uma jazz-band, e esta flexibilidade se dava pela necessidade de se adaptar às exigências do mercado musical da época. Pixinguinha tocava sax e flauta e, como novidade, foram incorporados mais dois instrumentos: uma bateria tipo americana e um trombone.

Em 1926, Pixinguinha entra para a Companhia Negra de Revistas, formada por artistas negros marginalizados pelas companhias existentes; foi nesta época que conheceu e se apaixonou por Albertina, sua companheira até o final de sua vida. 
O ano de 1928 foi muito importante na vida musical de Pixinguinha, pois assinou contrato com as gravadoras Parlophon e Odeon, que garantiram um total de 30 gravações - tanto de composições suas como outras em que era somente intérprete; o segundo acontecimento marcante deste mesmo ano foi a crítica negativa que ele e Donga, seu parceiro, receberam de Cruz Cordeiro, na revista Phono Arte. Nela, o crítico afirmou que as gravações de Lamentos e de Amigos do Povo demonstravam muita influência da música americana e os acusou de não serem brasileiros. Dois anos depois, a composição Carinhoso recebeu crítica semelhante, na qual Cordeiro declarou que a introdução era "um verdadeiro foxtrote".

Nessa época Pixinguinha, aparece nas gravações em grupo com nomes diferentes, como por exemplo: Pixinguinha e Conjunto, Orquestra Típica Oito Batutas, Orquestra Típica Pixinguinha e Donga e Orquestra típica Pixinguinha.

Entre as décadas de 20 e 30 houve uma revolução no processo de gravação, que passou de mecânico a elétrico. Isto fez com que a música popular fosse, através das rádios e das vitrolas - que agora tinham um preço mais acessível para a população - mais consumida pela sociedade.

Em 1929 Pixinguinha forma a Orquestra Victor Brasileira; essa orquestra, além de executar música instrumental, tinha como objetivo acompanhar cantores. Ele tinha dois contratos com a RCA Victor: um como arranjador e regente e outro como instrumentista. Segundo Sergio Cabral: "não há nenhum exagero em afirmar que, a partir deste trabalho, Pixinguinha criou o arranjo brasileiro de música popular". Além desta orquestra, Pixinguinha criou e dirigiu outras, como a Orquestra Típica Victor, Diabos no Céu, Orquestra Brunswick, Orquestra Columbia. Em 1932, formou o Grupo da Guarda Velha que, pelo grande sucesso que fez, passou a ser solicitado para acompanhar os maiores astros da época.

Após o advento do cinema falado, a classe musical passou a enfrentar uma séria crise de desemprego, já que a música ao vivo executada nos cinemas já não existia mais; além disso, as gravadoras não tinham condições de absorver todos esses músicos. Porém, Pixinguinha não foi muito afetado por essa crise, pois continuou participando de inúmeras gravações, além de se apresentar ao vivo com vários grupos. 
Mesmo assim, amigos sempre o aconselhavam a estudar teoria musical para complementar sua formação, que sempre foi prática e intuitiva. Outros, como seu amigo e professor catedrático de Harmonia e Contraponto da Escola Nacional de Música, Paulo Silva, se espantavam com a qualidade de suas instrumentações mesmo sem ter freqüentado cursos acadêmicos de música. O certo é que Pixinguinha acabou se inscrevendo no Instituto Nacional de Música e recebeu um certificado do curso de Teoria em 1933.

De 1940 a 1946 a carreira de Pixinguinha não apresentou grandes acontecimentos nem modificações; em sua vida pessoal ele sempre lutou com problemas financeiros, mas especialmente nesse período passou por grandes dificuldades, como afirma Silva e Oliveira Filho:

Apesar de tudo, o dinheiro era pouco, a casa estava a pagar, Pixinguinha bebia, as mãos tremiam, e flautista precisa de movimentos precisos. Para completar, um problema dentário obrigou-o a colocar uma ponte e, diminuindo a sensibilidade labial... lá se foi a embocadura! E a casa para pagar. Pixinguinha largou a sua flauta e se ligou definitivamente ao saxofone, que até aqui só tocara esporadicamente. (p.105)

Em 1946, Benedito Lacerda, flautista e compositor, o convidou para formar uma dupla, com Pixinguinha ao saxofone e Benedito à flauta. Entre 1946 e 1951 gravaram 34 fonogramas, com músicas sempre de autoria de ambos. Todos sabiam das dificuldades financeiras de Pixinguinha e Benedito o ajudou muito com suas dívidas; em troca, recebeu as parcerias dos choros que, certamente, eram somente de Pixinguinha. ${ }^{28}$

Com relação à nossa pesquisa, esta é a fase mais importante de sua vida, pois é justamente quando ele começa a criar, ao saxofone, suas linhas de contracanto. É importante ressaltar, porém, que Pixinguinha já havia gravado alguns acompanhamentos - com flauta - fazendo contracantos, com os Oito Batutas, e também em 1940, quando o maestro Leopold Stokowski veio ao Brasil para fazer algumas gravações.

Caldi (2000) assinala:

\footnotetext{
${ }^{28}$ Benedito Lacerda (1903-1958) - grande flautista e compositor conseguiu um contrato com a RCA Victor e a Irmãos Vitale para a edição e gravação de 25 músicas, para isso convidou Pixinguinha, que se tornaria seu parceiro em todas as músicas mesmo as que ele não tivesse nenhuma participação (encarte de Benê/trilogia musical da obra do polêmico e original Benedito Lacerda).
} 
Os contracantos agudos de Pixinguinha à flauta já são "costurados", como os que faria mais tarde ao sax tenor. A constância é a mesma, ou seja, Pixinguinha "contracanta" sem parar, duelando com a melodia principal, trazendo mais uma vez à tona seu espírito solista. E o que é mais interessante: mesmo tratando-se de gêneros diferentes e de instrumentos de registros distantes - que por isso resultam em relações distintas com a harmonia-, Pixinguinha se utiliza de padrões rítmicos e melódicos muito parecidos nos contracantos de flauta de 1940 e nos de saxofone de 1946 a 1950, com Benedito Lacerda. (p.13)

Em 1954, o 1ํ Festival da Velha Guarda reuniu um grupo de músicos veteranos e, entre eles, Pixinguinha, Donga, Benedito Lacerda, João da Baiana, Bororó e muitos outros. No ano seguinte, aproveitando o sucesso do festival, o grupo resolveu formar o conjunto "Velha Guarda", agora em caráter regular. Este grupo fez muito sucesso e, em apenas dois anos, gravaram três discos memoráveis.

Em 1958 sofre uma crise cardíaca, provavelmente ocasionada pelo excesso de trabalho do ano anterior, no qual gravou vários discos.

Foi convidado para fazer a trilha sonora do filme "Sol sobre a lama", em 1962 - até então, um trabalho inédito em sua vida - tendo como parceiro Vinicius de Morais. Duas músicas fizeram muito sucesso: Lamento e Mundo Melhor. Dois anos depois sofre outro enfarte e, desta vez, permanece um mês internado. Ainda assim, em 1966 volta a tocar saxofone.

Após 45 anos de convivência, em 1972 falece sua companheira Beti. A saúde de Pixinguinha, que já não era boa, piora muito e, no ano seguinte, falece aos 75 anos.

Em sua vida Pixinguinha fez muitas gravações, e com diferentes grupos. Era comum ele participar de várias formações, inclusive ao mesmo tempo. Não seria de muita utilidade para nós dividirmos sua obra pensando somente em uma ordem cronológica e, por isso, achamos relevante separarmos as fases a partir de algumas gravações dos grupos dos quais ele participava. Esta divisão foi influenciada pela publicação Casa Edison e seu tempo. 
Separamos sua obra em 5 fases:

1) Grupo Choro Carioca, de 1910 a 1915;

2) De 1919 a 1930: Grupo do Pechinguinha (sic) ${ }^{29}$

3) Grupo Oito Batutas, no ano de 1923;

4) As gravações com Benedito Lacerda, de 1946 a 1951;

5) Suas gravações com as Orquestras das quais ele era o arranjador: Orquestra Victor Brasileira e Diabos do Céu.

Como já foi dito, esta divisão é de caráter didático, pois Pixinguinha sempre atuou em várias áreas e grupos, e não é nosso objetivo nos aprofundarmos em questões sobre sua vida e obra de uma maneira geral, e sim examinarmos o seu lado criativo nas gravações.

1) Grupo Choro Carioca e Grupo Carioca:

Foi com estes grupos que Pixinguinha realizou suas primeiras gravações, que datam de 1910 a 1915. O grupo Choro Carioca era formado por Irineu de Almeida (bombardino e Oficleide), Bonfiglio de Oliveira (trompete), seus irmãos Leo e Otavio (violões) e Henrique (cavaquinho). Já o Grupo Carioca, pelo trombonista Candinho Silva, Nelson Alves ao cavaquinho e Tute, no violão de sete cordas.

O que podemos observar nessas primeiras gravações é que, enquanto Pixinguinha executa as melodias na flauta, seu grande mestre e incentivador Irineu de Almeida toca, no oficleide, linhas de contracanto que dialogam com a melodia principal. É importante notar que as linhas executadas por Irineu influenciaram Pixinguinha posteriormente, tanto em suas gravações com a flauta quando acompanhava, como ao saxofone nas gravações com Benedito Lacerda, como já foi examinado no capítulo anterior.

\footnotetext{
${ }^{29}$ Assim registrado nos discos originais.
} 
2) De 1919 a 1930: Grupo do Pechinguinha, Pixinguinha e seu conjunto etc.

No período que vai de 1919 até 1930, existem gravações históricas nas quais Pixinguinha toca flauta, acompanhado ora pelo Grupo do Pechinguinha, ora pelo Pixinguinha e seu conjunto, Choro Pixinguinha ou somente Pixinguinha. Nesta fase, encontramos Pixinguinha tocando as melodias sempre com uma interpretação muito característica dele, com virtuosismo acima da média, apesar da precariedade das gravações. Somente em 1927 as gravações passaram para o sistema elétrico, o que possibilitou um volume maior de gravações, impulsionando sua carreira, agora como arranjador e diretor de orquestras.

Em 1930 grava o choro O Urubu e o Gavião, baseado no tema popular do Urubu Malandro, que já havia sido gravado em 1923 com os Oito Batutas. O que podemos notar é que, apesar de uma interpretação muito parecida nas duas gravações, ele criava variações na melodia com grande facilidade e liberdade, utilizando o instrumento de forma original.



Os Oito Batutas em sua formação original: Jacob Palmieri, Donga, José Alves Lima, Nélson Alves, Raúl Palmieri, Luiz Pinto da Silva, China e Pixinguinha. (www.mpbantiga.blogspot.com) 
3) Grupo dos Oito Batutas (1923):

Esse talvez seja um dos períodos mais férteis da carreira de Pixinguinha. $\mathrm{O}$ grupo foi criado com o objetivo de tocar na sala de espera do Cine Palais e, como já foi dito, teve muito sucesso, viajaram à Paris e depois para a Argentina, onde fizeram um total de 20 gravações. Nestas gravações podemos ouvir Pixinguinha ao saxofone pela primeira vez.

Pixinguinha sempre se adaptou ao mercado e compunha, além de choros, fox-trots e shimmys. Esta flexibilidade sempre fez parte da vida dos músicos brasileiros, que assimilavam as novidades estrangeiras e as mesclavam com as tendências musicais brasileiras. Pixinguinha comenta sobre estas influências:

MIS: Mas você andou tocando shimmy também?

PIX: Só tocava comercialmente. A gente ia aos bailes e só tocava o que era nosso. Uma vez ou outra é que tocávamos um foxtrotezinho só para variar, porque, comercialmente, nós tínhamos que tocar um bocadinho de cada coisa. (depoimento ao MIS_RJ, p. 64).

Muito se escreve sobre a influência do jazz nos grupos do começo do século, e se esta influência descaracterizou ou não a música brasileira; nesta época, as orquestras não se pareciam com o que hoje denominamos orquestra de "jazz". ${ }^{30}$

O que queremos ressaltar é que esses músicos, tanto Pixinguinha como qualquer outro músico popular da época, só conseguiriam sobreviver dentro do mercado de trabalho adaptando-se aos gostos e modas do público e da época.

\footnotetext{
${ }^{30}$ Segundo Ikeda (1984), pode-se afirmar, com grande probabilidade de acerto, que a música jazzística chegou ao Brasil por volta de 1917 com a companhia teatral das American Girls e o baterista de 11 instrumentos; nos momentos iniciais do jazz no Brasil a principal característica foi o uso da bateria "tipo americana", o autor ainda afirma que Pixinguinha provavelmente já teria entrado em contato com o jazz antes mesmo de sua viagem à Paris, pois quando estiveram em São Paulo em 1919, a grande atração da cidade era a famosa Banda de jazz de Kosarin, que causava furor na época (p.116 a 118).
} 


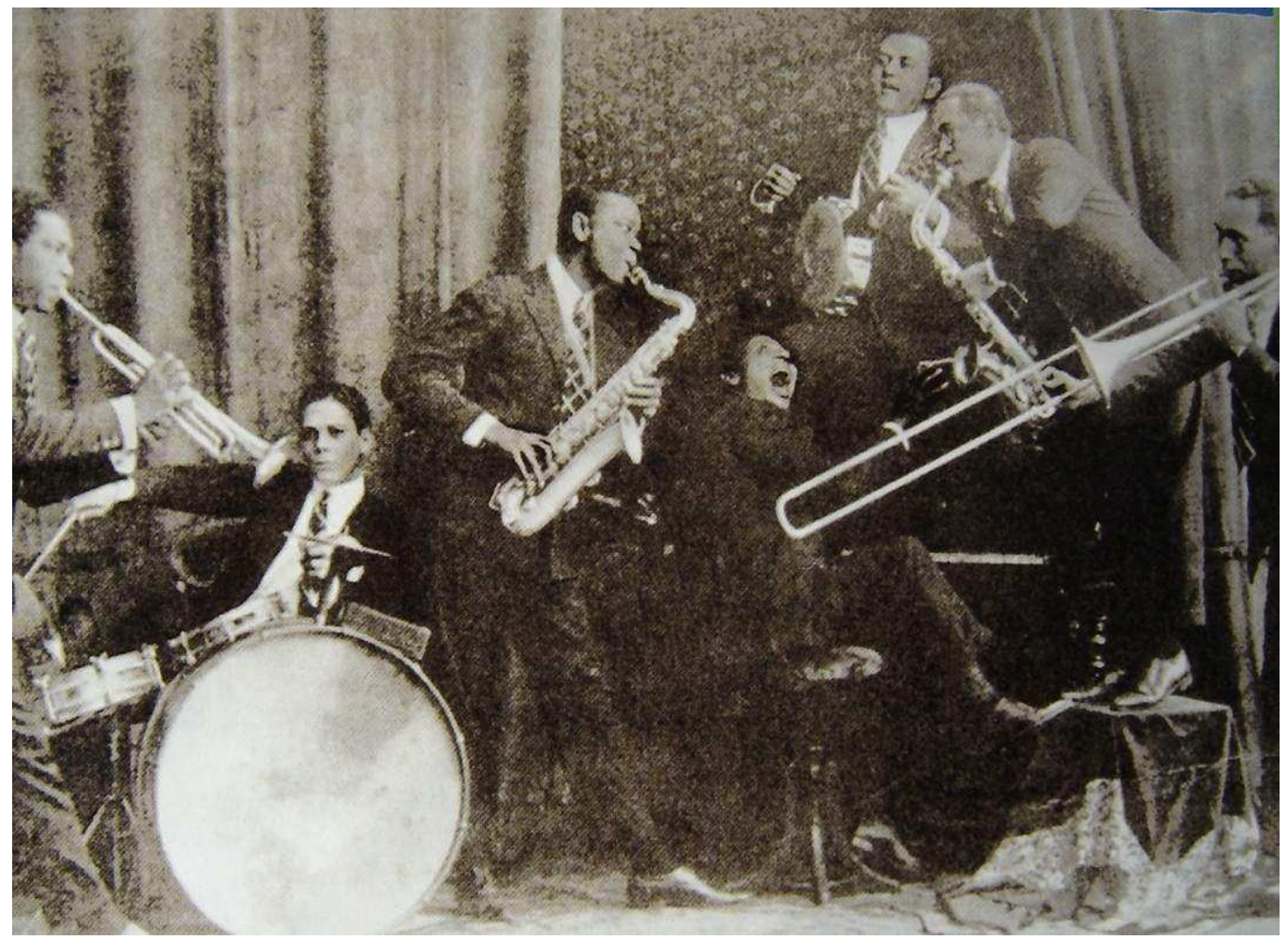

Os Oito Batutas durante a excursão à Argentina, em 1923. (www.mpbantiga.blogspot.com)

4) As gravações com Benedito Lacerda (de 1946 a 1951)

Apesar de toda polêmica gerada em torno da questão da verdadeira autoria dos choros da dupla, vale salientar a importância destas gravações na caracterização do estilo que Pixinguinha desenvolveu a partir desse momento, pois nelas Pixinguinha executa, ao saxofone, suas famosas linhas de contracanto, enquanto Benedito Lacerda toca a melodia na flauta.

É clara a similaridade com suas primeiras gravações feitas entre 1910 e 1914 com o Grupo Choro Carioca, nas quais o oficleide de seu mestre Irineu de Almeida dialogava com sua flauta. A grande diferença é que o que antes era executado pelos instrumentos graves, agora passava para uma linha mais aguda, com o saxofone.

5) Pixinguinha e as Orquestras:

Segundo Paes (2000, p.27), os arranjadores que trabalhavam na indústria fonográfica brasileira eram quase todos estrangeiros e tinham influência das operetas e da música ligeira européia. Pixinguinha vinha das tradições das bandas militares brasileiras, trazendo daí influências para seus arranjos. Inaugurou, a partir 
dessa experiência, uma forma brasileira de fazer arranjos, valorizando o naipe de percussão e incorporando as técnicas dos contracantos que já utilizava como intérprete.

Em 1929, a RCA Victor promoveu um concurso para orquestrador; Pixinguinha se inscreveu com uma orquestração de Carinhoso, ganhou o primeiro lugar e um contrato com exclusividade. Com esta orquestra, realizou até 1935 mais de 350 gravações dos mais variados gêneros.

Outra importante orquestra da qual foi arranjador e maestro foi a Diabos do Céu, criada em 1932 e constituída, basicamente, pelos mesmos músicos do Grupo da Guarda Velha. Com esta Orquestra gravou 252 músicas, sendo a maioria frevos, e apenas seis instrumentais. Pixinguinha ainda compôs, entre 1938 e 1940, arranjos sinfônicos que, segundo Barbosa (p.98), se encontram no arquivo de seu filho Alfredinho.

\section{2 - Análise dos improvisos}

Para a análise dos choros de Pixinguinha, utilizaremos como ferramenta a relação entre o acorde dado e as notas da melodia criada sobre este mesmo acorde. Esse modo de análise nos parece mais adequado para demonstrar se seus improvisos estão fundamentados principalmente em estruturas verticais (baseadas em notas de acorde) ou horizontais (baseadas em escalas referentes às seqüências harmônicas) $)^{31}$.

Não é nossa intenção analisar nota por nota de cada improviso, mas mostrar as características mais importantes da abordagem de Pixinguinha. O número colocado abaixo de cada nota refere-se ao intervalo que essa nota faz com o acorde relacionado a ela. Procuramos analisar apenas as notas presentes no tempo forte, e as mais importantes na definição do acorde: 1 para as fundamentais, 3 para as terças e 7 para as sétimas. As quintas não serão enumeradas por não serem consideradas definidoras dos acordes. Vale ressaltar que as antecipações dos tempos fortes serão consideradas.

\footnotetext{
${ }^{31}$ No capítulo referente à improvisação encontramos exemplos dessas estruturas.
} 
Colocamos uma marcação específica para indicar os arpejos e as tríades; denominamos tríade o arpejo de três notas $(1 / 3 / 5)$ e arpejo à tétrade (1/3/5/7). Em alguns casos encontramos cromatismos que serão marcados com as letras " $\mathrm{Cr}$ ". Nos trechos em que o autor utiliza uma abordagem horizontal, indicaremos com as letras AH. Utilizamos cifra quando nos referimos a acordes; para notas, seu respectivo nome.

Ao final das análises, faremos uma tabela de cada improviso, relacionando o número de vezes em que encontramos fundamentais, terças e sétimas no tempo forte.

\section{1 - Um a Zero}

Este é um choro composto na forma tradicional em três partes: A, B e C.

Sua forma é a seguinte: AABAACCA ${ }^{32}$.

Tonalidade da parte A: Do Maior.

Tonalidade da parte B: Sol Maior

Tonalidade da parte C: Fá Maior

O improviso é executado ao sax tenor enquanto a melodia é feita pela flauta.

Parte A - primeira exposição (compassos 1 a 16):

O improviso se inicia com uma linha descendente (Sol-Fa-Mi) do primeiro para o segundo compasso para alcançar a terça do acorde seguinte. Pixinguinha parte de uma nota que não define propriamente a harmonia (a quarta de $\mathrm{Dm}$ ), no entanto, como a linha melódica desce por graus conjuntos esta alteração soa com naturalidade. Do compasso 1 ao 3, com exceção desta quarta inicial, o autor apresenta fundamentais (1), terças (3) e sétimas (7) nos tempos fortes, junto com um arpejo de $\mathrm{C}$ no compasso 2. Consideramos a nota Ré deste arpejo, que é a nona do acorde, como nota de passagem.

\footnotetext{
${ }^{32}$ Consideramos a parte B sem repetição, a harmonia é a mesma, mas o tema é diferente; podemos dizer que é um tipo de variação.
} 
Do compasso 4 ao 7 encontramos uma condução melódica realizada através de graus conjuntos descendentes também em tempos fortes que correspondem à linha do baixo da harmonia, importante característica do autor.

Compasso 8: arpejo de G7- terça e fundamental em tempo forte.

Compasso 9 e 10: repetição do primeiro compasso e uma tríade de $C$ seguida por cromatismo para o próximo compasso (11), que também possui uma nota cromática conduzindo a melodia por graus conjuntos até as terças do compasso 12.

Nos compassos 13 e 14 - fundamentais no tempo forte, seguidos dos compassos 15 e 16, onde encontramos nos tempos fortes sempre as fundamentais dos acordes - o que revela um caráter fortemente conclusivo, harmonicamente falando.

Exemplo 1: Contraponto de 1 a 0 , compassos 1 a 16
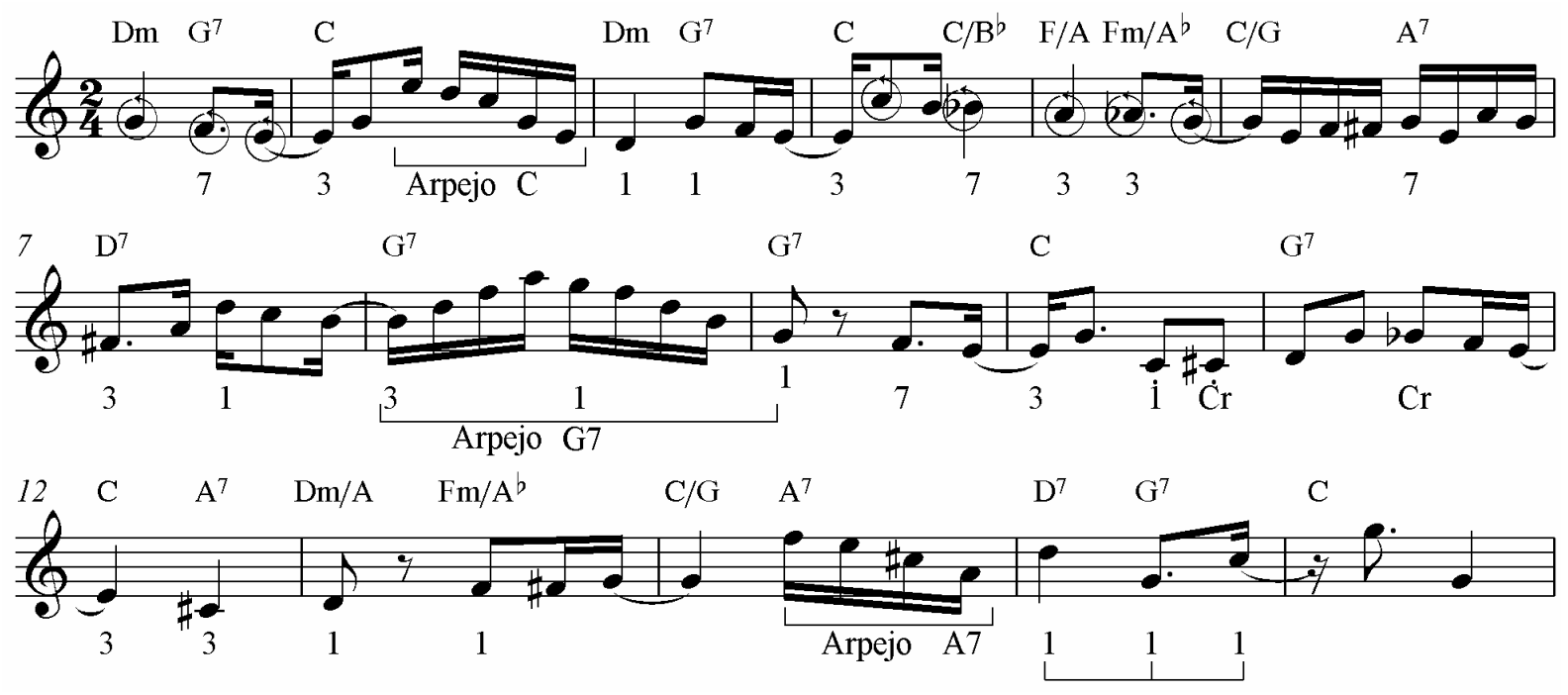

Parte A - segunda exposição (compassos 17 a 32):

Compasso 17 a 19: encontramos aqui um exemplo de abordagem horizontal, pois o autor usa apenas um trinado por três compassos sem definir claramente a harmonia.

A seguir, até o compasso 27 , há uma repetição do que ocorre na primeira exposição da parte A. Nos compassos 28,29 e 30 encontramos uma idéia já empregada anteriormente, onde Pixinguinha descreve a linha descendente do baixo. 
Nos dois últimos compassos, como da primeira vez, ele conclui com fundamentais no tempo forte.

Exemplo 2: Contraponto de 1 a 0 , compassos 17 a 32

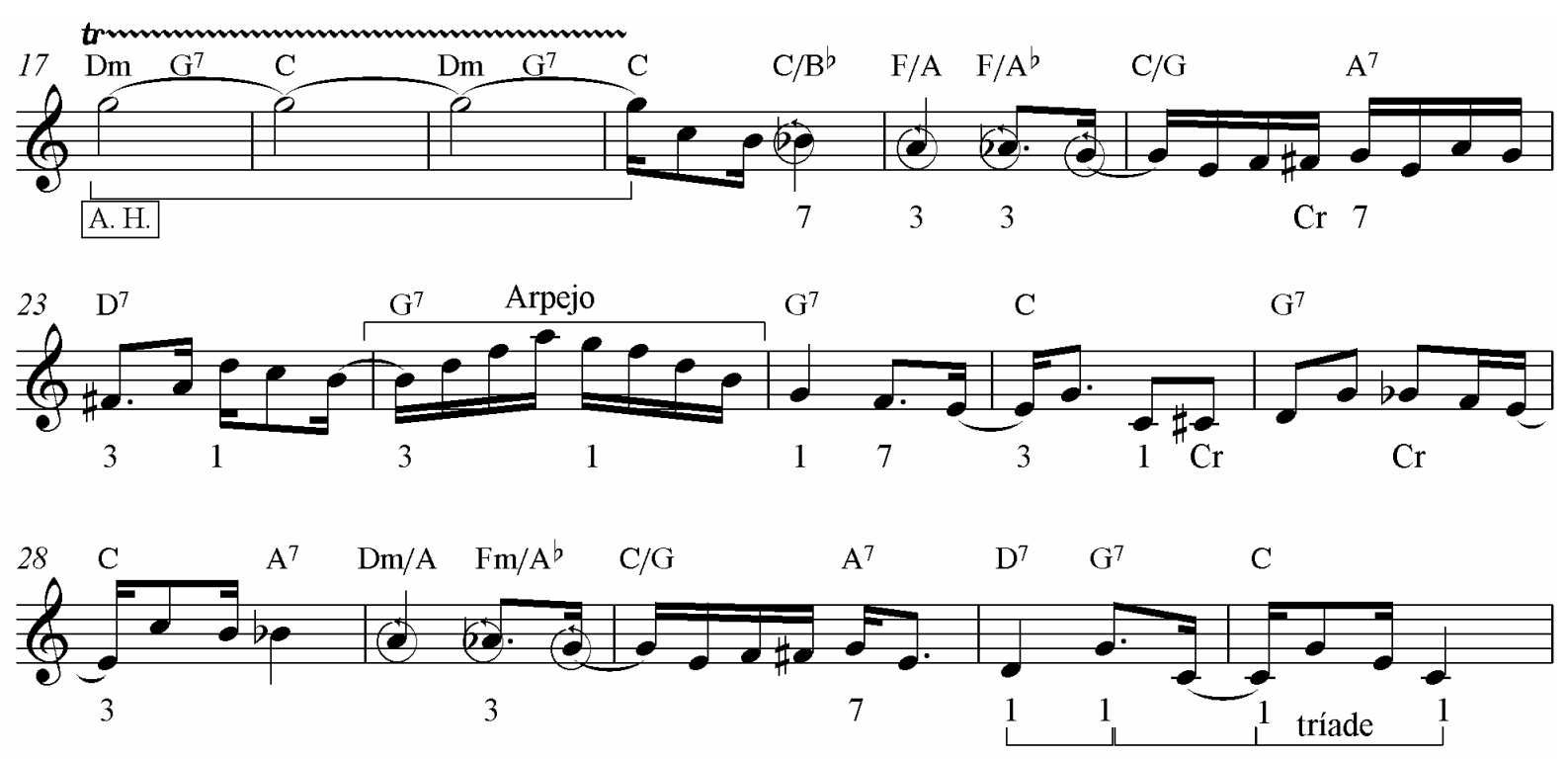

Parte B - primeira parte (compassos 33 a 48):

A parte $B$ deste choro está em $G$ maior, e inicia-se com uma clara abordagem horizontal $(\mathrm{AH})$ nos primeiros sete compassos.

Denominamos de frase A, a que ocorre nos compassos 33 e 34 e se repete integralmente nos compassos $35 / 36$ e 37/38. Com um motivo rítmico marcante, essa frase é uma citação do acompanhamento da Aquarela do Brasil, de Ari Barroso e, como característica de horizontalidade, encontramos a repetição da mesma frase enquanto a harmonia se modifica. Nota-se que a repetição da frase tem mais importância que a definição dos acordes, somente no compasso 37 é que encontramos uma fundamental em tempo forte.

No compasso 39 ouvimos a repetição da primeira semifrase seguido de um arpejo de Em no compasso 40, retornando para a abordagem vertical. Nestes dois compassos a harmonia não está bem delineada pelas notas utilizadas.

Nos compassos seguintes encontram-se fundamentais, terças e quintas definindo os acordes, e um arpejo de Am no compasso 44. A seguir, no compasso 
45, o autor usa a fundamental e a terça no tempo forte sobre um acorde de C\#dim; no próximo compasso - a tríade de $\mathrm{E}$.

Antes da passagem para a segunda parte da parte B, no compasso 47, observamos a tradicional sequência de fundamentais seguida por um elemento de ligação que o autor utiliza para retornar para a parte B.

\section{Exemplo 3: Contraponto de 1 a 0, compassos 33 a 48}
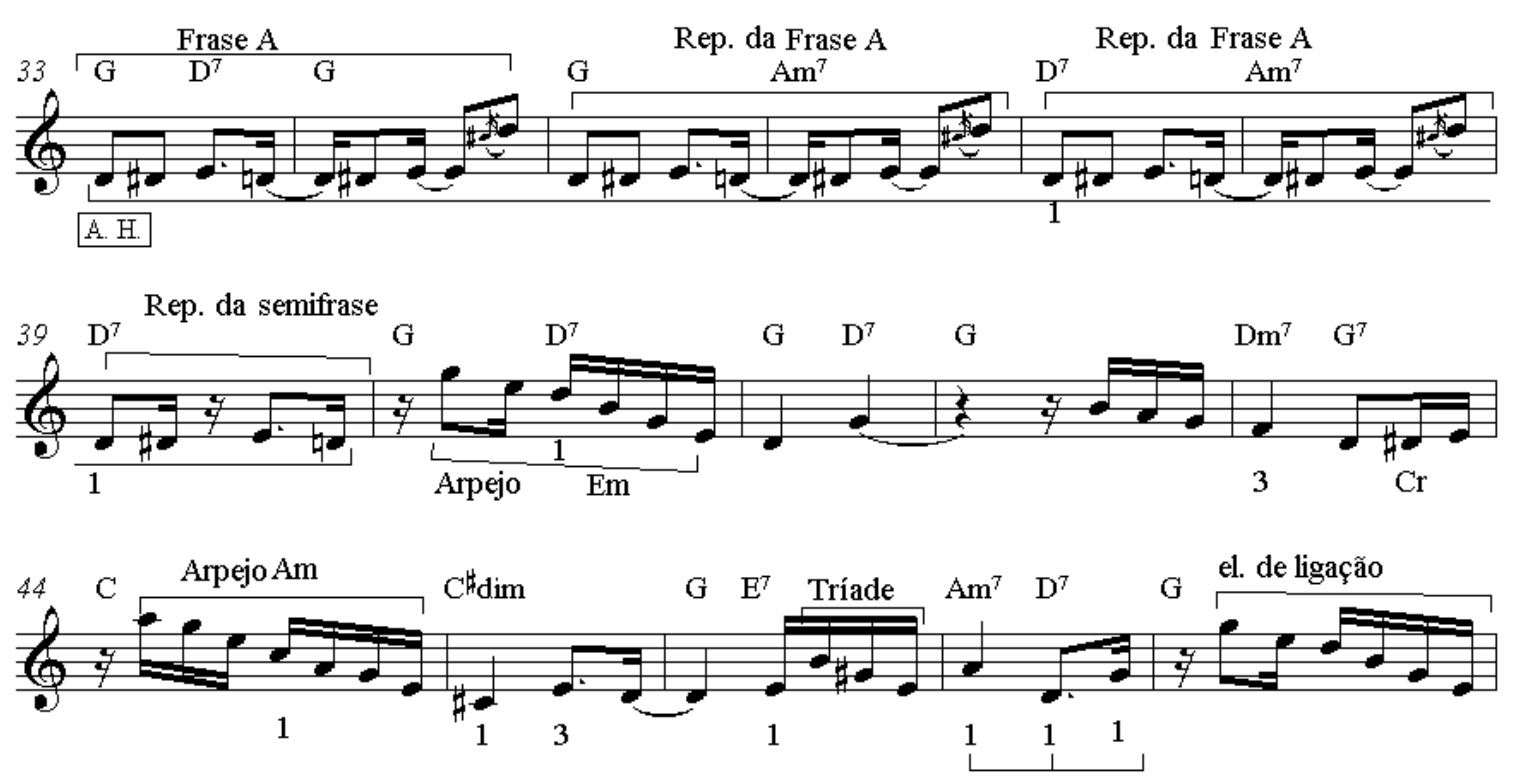

Parte B - segunda parte (compassos 49 a 64):

Nos primeiros sete compassos desta seção encontramos uma repetição integral, diferente apenas no compasso 56 - onde o autor finaliza a frase A.

Nos compassos 57 e 58 mais uma repetição da frase $A$, desta vez com caráter de finalização resolvendo na nota Ré.

Do compasso 59 até o final desta seção que termina no compasso 64, encontramos praticamente as mesmas notas, e nota-se que nos últimos dois compassos os tempos fortes sempre são marcados pelas fundamentais. 
Exemplo 4: Contraponto de 1 a 0, compassos 49 a 64
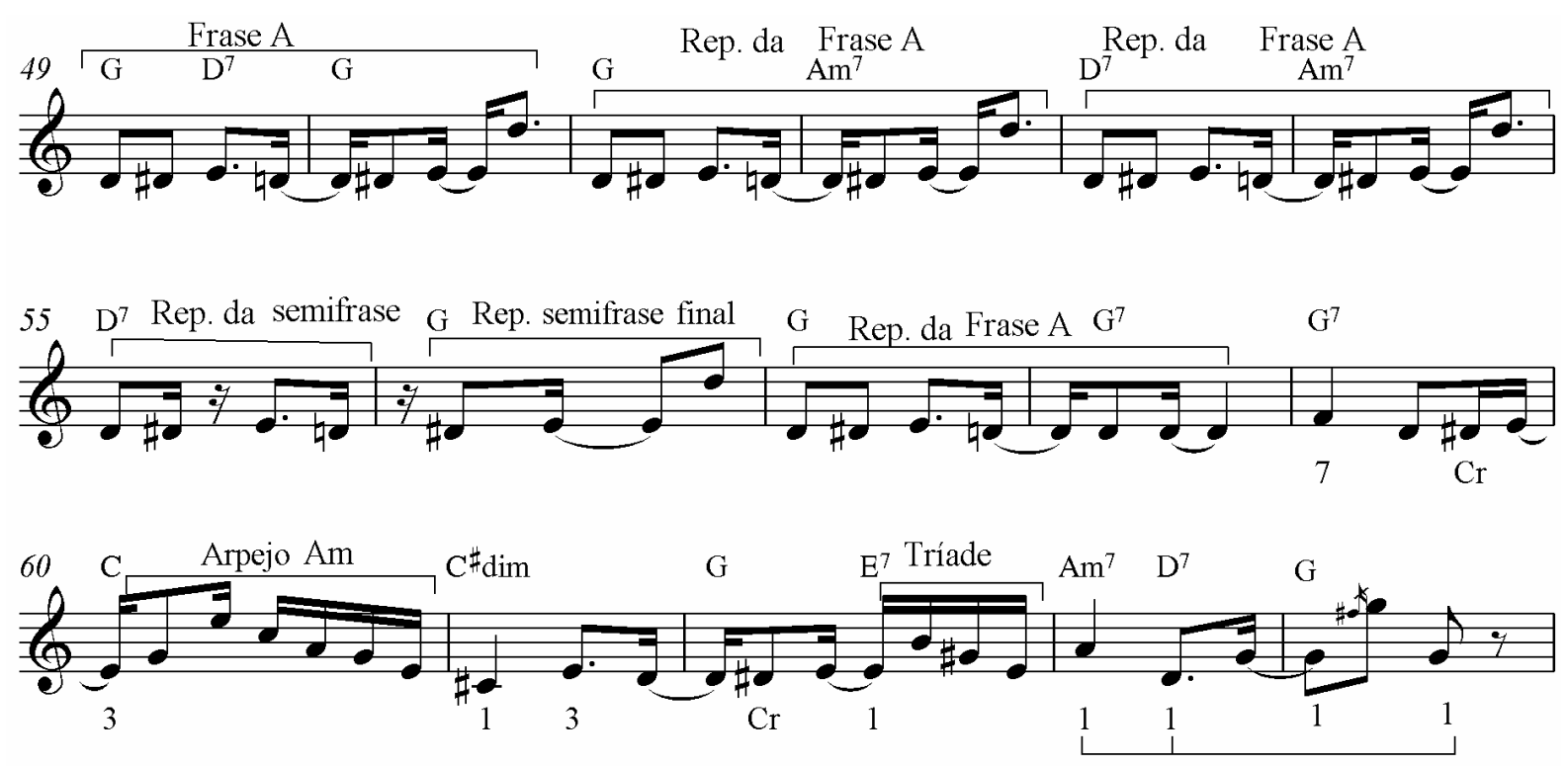

Parte A - terceira exposição (compassos 65 a 80):

Nos dois primeiros compassos percebemos um motivo formado com material do tema, que já se anuncia no final do período anterior (compasso 64) e segue em parte até o compasso 67 , consideramos nesses compassos iniciais uma abordagem horizontal pela utilização de notas repetidas com mudanças rítmicas. A seguir existem poucas diferenças em relação à sua primeira apresentação. Encontramos sempre terças e sétimas nos tempos fortes e a mesma sequência de baixos descendentes. Observamos uma alteração no oitavo compasso onde há uma transição para uma abordagem horizontal. Este motivo, que já vimos anteriormente, desta vez aparece noutro lugar, com um trinado de G que dura quatro compassos.

A seguir, descreve claramente um arpejo de C7 b9 (compasso 76). Nos quatro últimos compassos desta parte encontramos um cromatismo (do 77 para o 78), uma tríade de $\mathrm{A}$ e a conclusão com as fundamentais no tempo forte. 
Exemplo 5: Contraponto de 1 a 0 , compassos 65 a 80
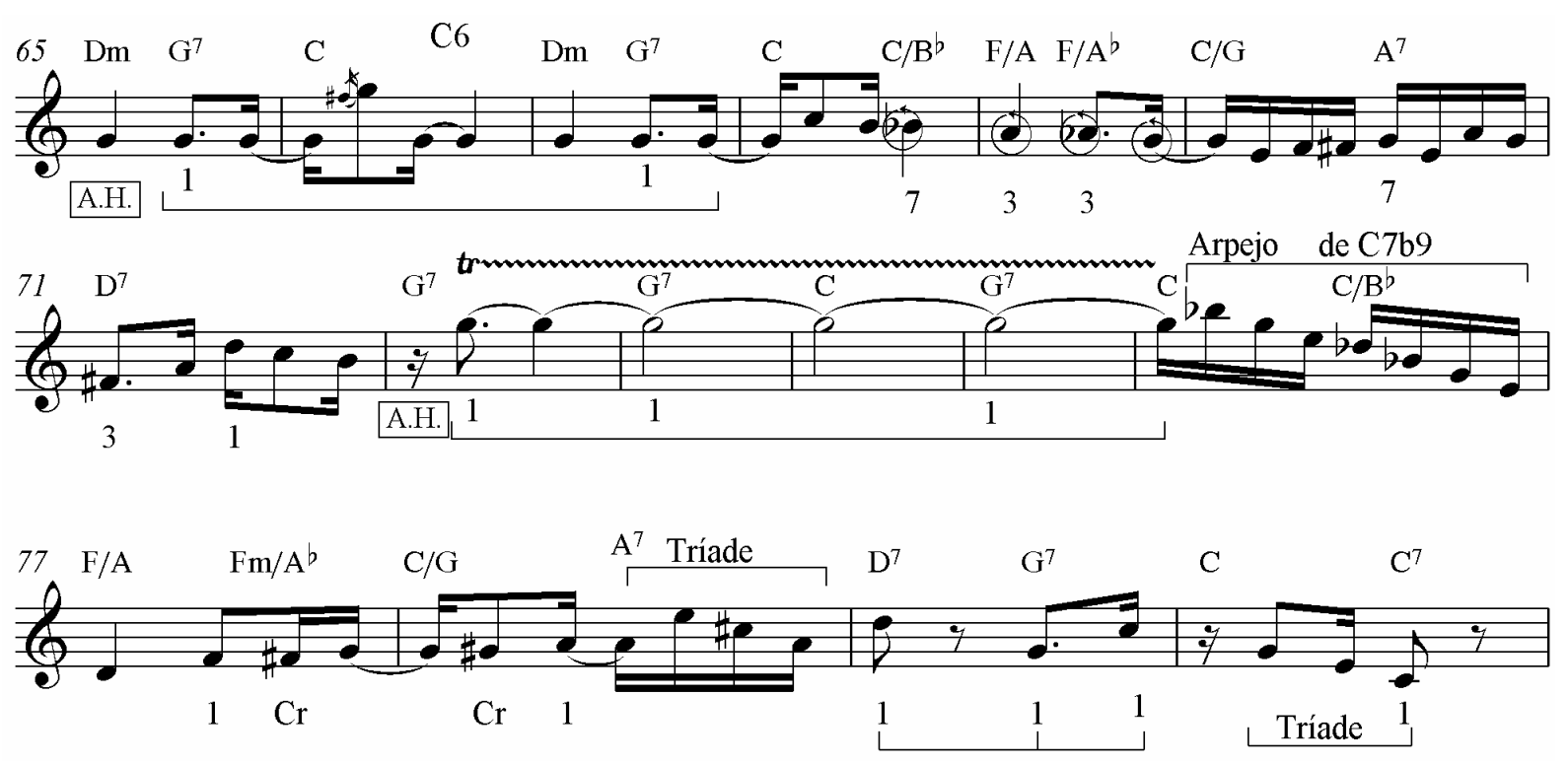

Parte C - primeira exposição (compassos 81 a 96):

Esta parte é composta por dezesseis compassos, e está em Fa Maior.

Inicia-se esta seção com uma nota longa que vai do compasso 81 ao 83, e contrasta claramente com a frase seguinte (compassos 84 e 85 ) denominada de frase B. Esta frase de característica cromática, dura dois compassos e se repetirá nos compassos 86 e 87, em uma frase denominada B' com as mesmas características, porém começando uma sexta maior abaixo. Podemos considerar que a frase B' é apresentada com um deslocamento rítmico em relação à frase B, porque no segundo tempo do primeiro compasso até o primeiro do seguinte, encontramos as mesmas notas do primeiro compasso da frase B. No trecho todo consideramos a abordagem como horizontal.

Nos compassos 88 e 89, ainda com abordagem horizontal, temos uma frase, denominada $\mathrm{C}$, com motivos melódicos descendentes. A seguir retornamos à verticalidade com diversos arpejos definindo os acordes: D7 com b9 no compasso 90, Gm7 no 92, Bdim no 93 e a tríade de D no 94 finalizando com as fundamentais Sol - Do - Fa. 
Exemplo 6: Contraponto de 1 a 0, compassos 81 a 96
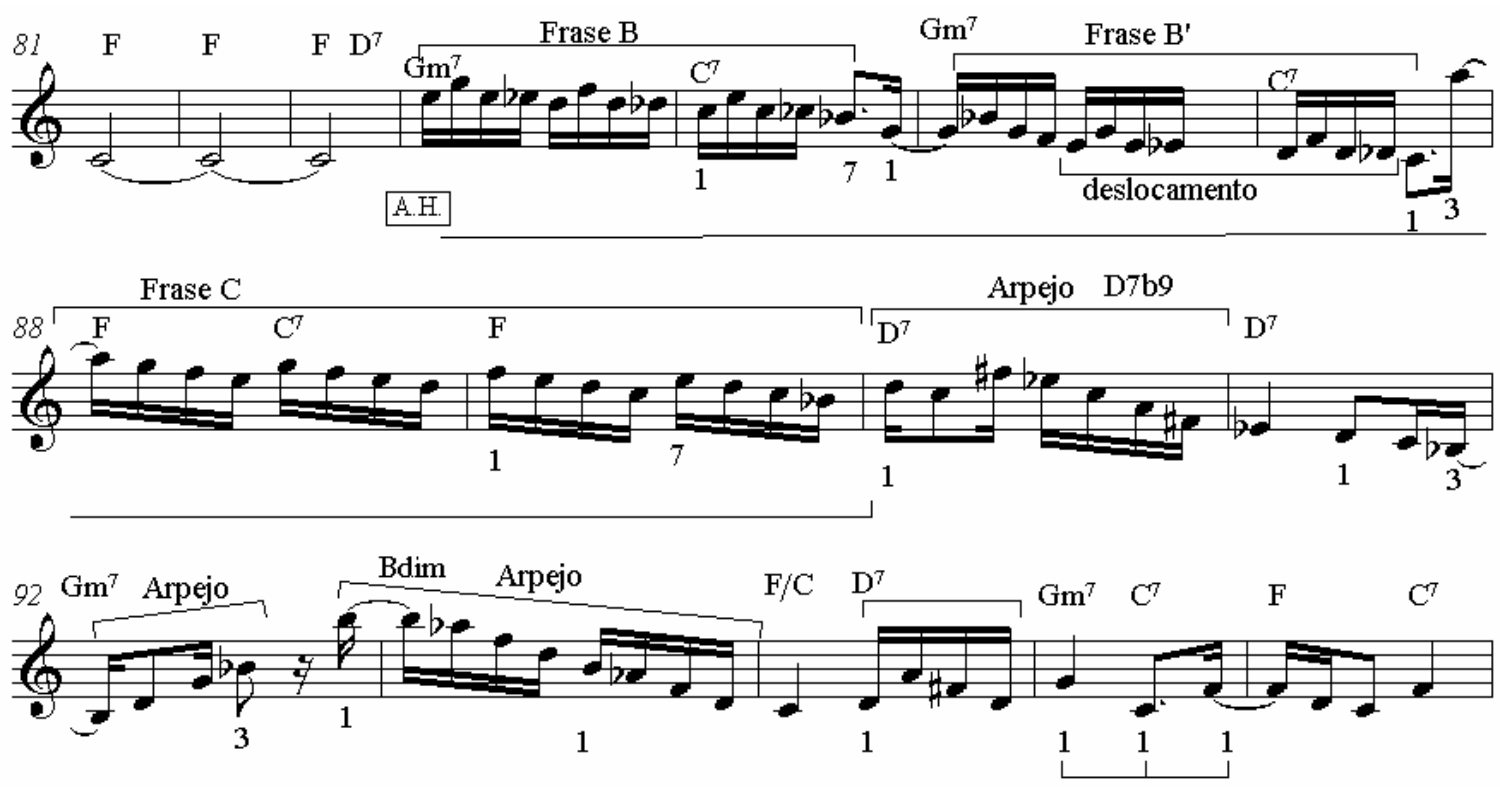

Parte C - segunda exposição (compassos 97 a 112):

Encontramos nos sete primeiros compassos uma repetição da primeira exposição da parte $\mathrm{C}$, observando apenas uma diferença no sétimo compasso, onde há um arpejo de $\mathrm{C} 7$.

Nos compassos 105 e 106 temos a fundamental e terça nos primeiros tempos seguida pelo arpejo de D7b9.

No compasso 107, o autor evidencia a seqüência dos acordes utilizando-se de fundamental e sétima no tempo forte. Nos compassos 108 e 109 há a definição completa dos arpejos de Gm e Bdim, e finalizando a seção, fundamentais no tempo forte e tríade. 
Exemplo 7: Contraponto de 1 a 0, compassos 97 a 112

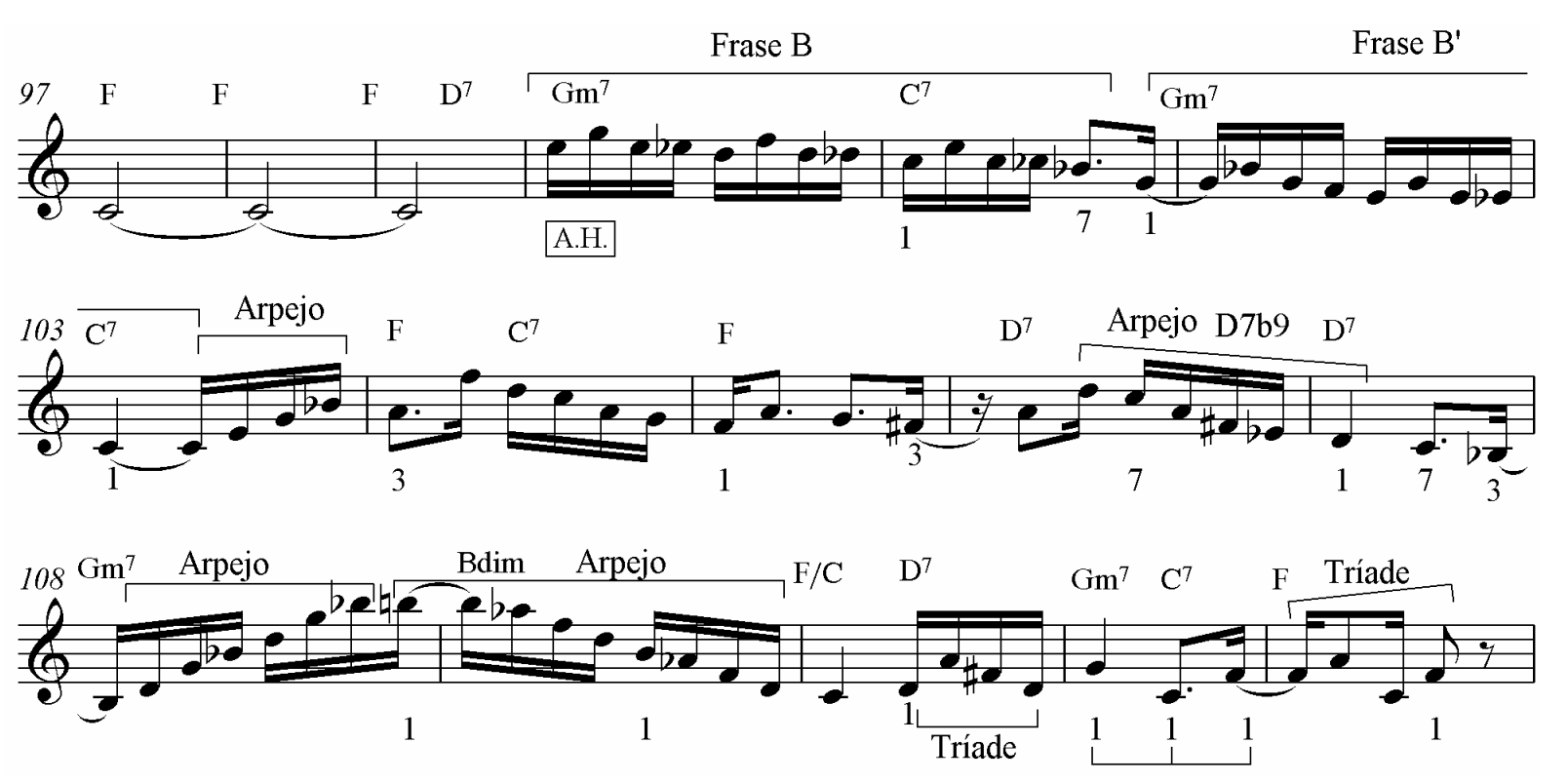

Parte A - última repetição (compassos 113 a 128):

O desenho dos quatro primeiros compassos sugere as duas abordagens simultâneas, ou seja, existem motivos rítmico-melódicos repetidos $(\mathrm{AH})$, com frases de dois compassos, sempre com notas do acorde: fundamentais e terças em tempo forte $(A V)$.

O compasso 117, procedente de um cromatismo, define a fundamental no segundo tempo e é seguido por outro cromatismo; nos próximos dois compassos encontramos notas do acorde.

No compasso 120 há uma frase cromática similar ao tema seguida por um arpejo de G7. No compasso seguinte, temos a terça no tempo forte, e no 122 a quinta no tempo forte.

No compasso 124, observamos um arpejo de A7b9, seguida de um desenho de baixos descendentes no compasso 125 e 126 e, para finalizar, as fundamentais no tempo forte e a tríade de $\mathrm{C}$. 
Exemplo 8: Contraponto de 1 a 0, compassos 113 a 128
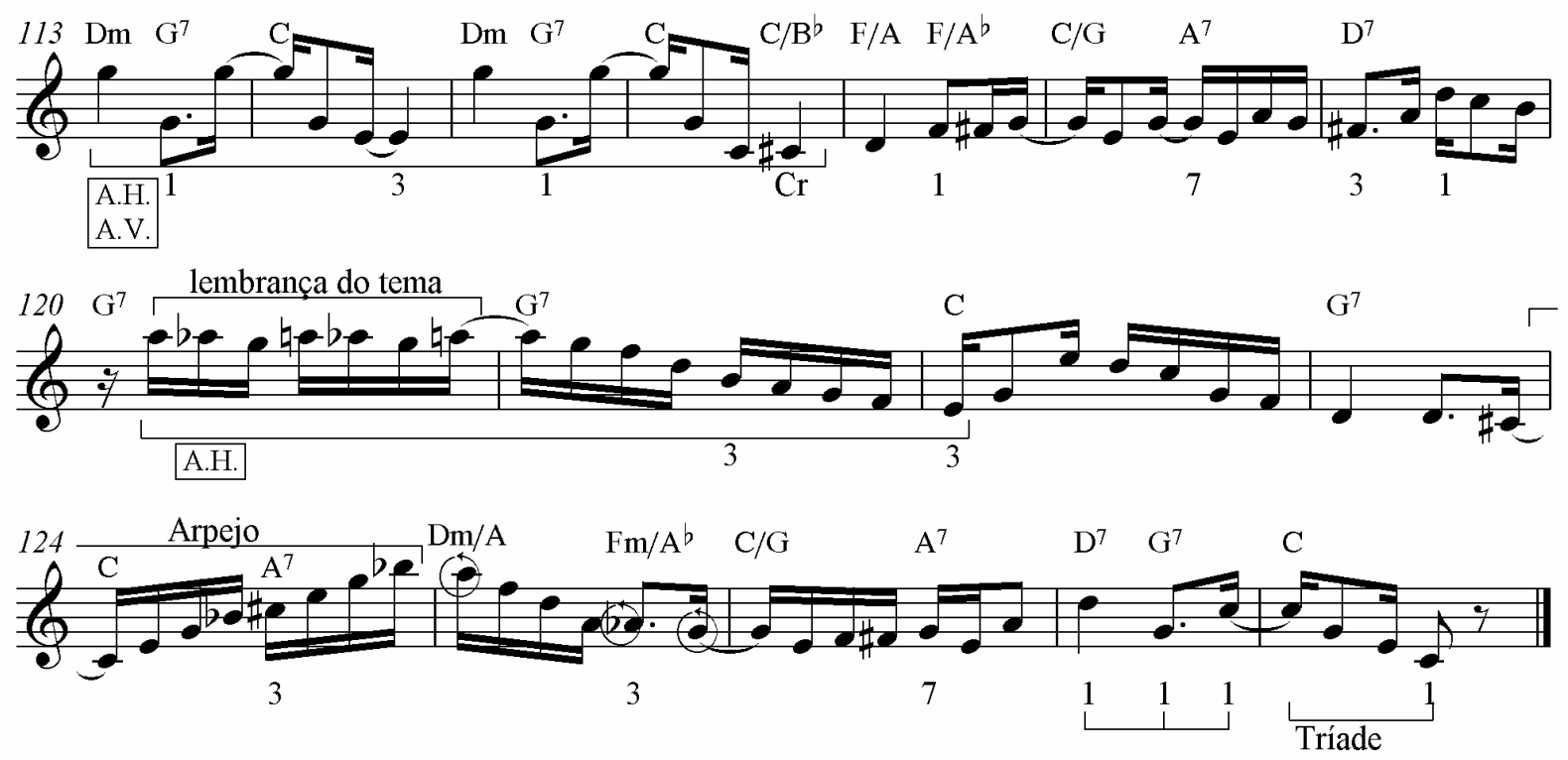

A seguir, uma tabela separada por seções com o número de vezes que o autor utiliza em tempo forte as fundamentais, terças e sétimas.

\begin{tabular}{|c|c|c|c|}
\hline Seções & Fundamental (1) & Terça (3) & Sétima (7) \\
\hline A1 & 11 & 9 & 4 \\
\hline A2 & 8 & 7 & 4 \\
\hline B & 17 & 4 & 1 \\
\hline A3 & 12 & 3 & 2 \\
\hline C1 & 12 & 3 & 2 \\
\hline C2 & 12 & 3 & 3 \\
\hline A4 & 8 & 6 & 2 \\
\hline
\end{tabular}

Tabela 1 


\section{$\underline{2.2-\text { Pagão }}$}

Este choro também é composto na forma tradicional, em três partes: A, B e C.

Notamos na forma desse choro uma diferença na terceira parte $(C)$, que possui 32 compassos e é tocada somente uma vez.

Sua forma é a seguinte: AABBACA

Tonalidade da parte A: Re Menor.

Tonalidade da parte B: Fá Maior

Tonalidade da parte C: Re Maior

Parte A - primeira exposição (compassos 1 a 16):

O improviso se inicia no segundo compasso do tema. Encontramos nos compassos 2, 3 e 4 praticamente fundamentais, terça e sétima dos acordes. Nos compassos 5, 6 e 7 temos uma linha melódica descendente, com células rítmicas repetidas. Compasso 8 , arpejo de $A 7$.

Compasso 9 até 12 sempre fundamentais, terças e sétimas em tempo forte encadeadas com escalas e arpejos.

Nota-se fundamentais e terças em tempo forte nos dois últimos compassos reforçando a harmonia no final da primeira exposição. No último compasso podemos considerar uma tríade de Dm apenas com uma aproximação cromática da quinta.

\section{Exemplo 9: Contraponto de Pagão, compassos 1 a 16}
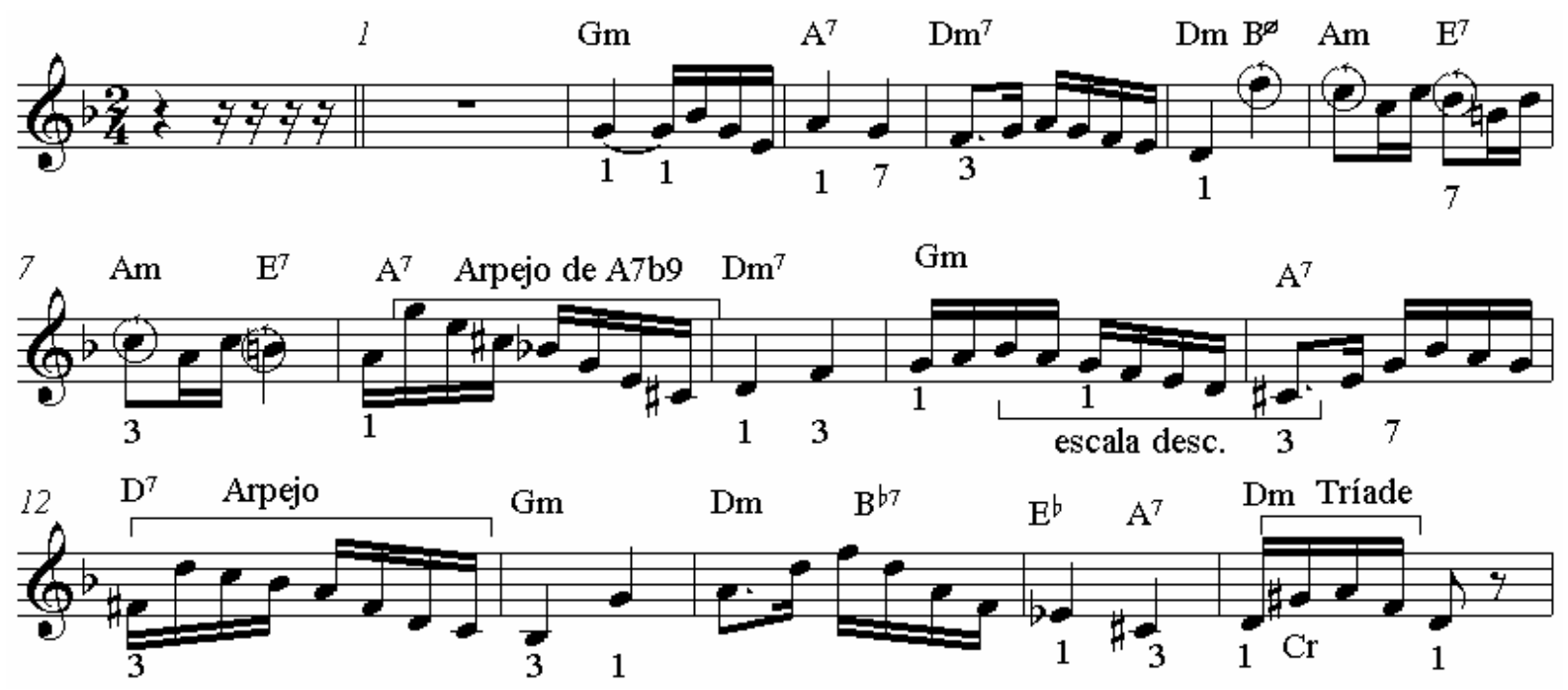
Parte A - segunda exposição (compassos 17 a 32):

Nos dois primeiros compassos desta seção ouvimos uma frase escalar descendente Re-Do-Si-La-Sol que nos leva à terça de A do compasso 19.

Encontramos a seguir as mesmas idéias da primeira exposição, apenas diferenciando-se ao final da seção, onde ouvimos as três fundamentais no tempo forte para seguir para a parte B.

Exemplo 10: Contraponto de Pagão, compassos 17 a 32
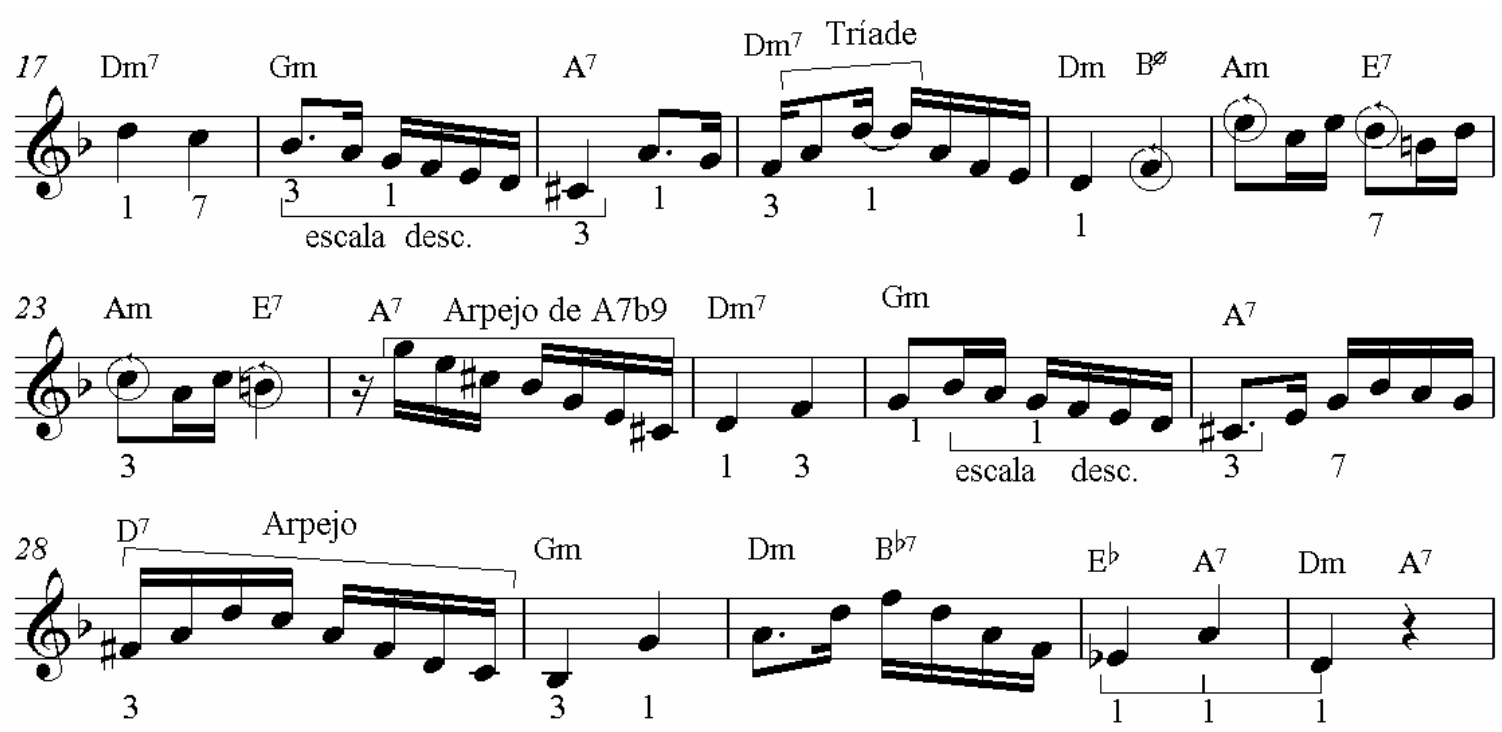

Parte B - primeira exposição (compassos 33 a 48)

Esta seção se inicia em Fa Maior. Nesta parte notamos diversas vezes o encadeamento dos acordes traçados pelas fundamentais, terças e sétimas, acompanhadas de notas cromáticas possibilitando maior fluência melódica às passagens.

Por exemplo, no compasso 33 temos a quinta de $\mathrm{F}$ e a terça de $\mathrm{D}$ seguida de Fá \# para se alcançar o G, que é a fundamental do acorde seguinte. Neste compasso temos uma tríade de $\mathrm{Gm}$ e no segundo tempo um trecho escalar para se atingir a nota Mi - que é a terça de C7 no compasso 20.

No compasso 36 encontramos um arpejo de Dm (relativa de F), e o uso de cromatismo no compasso 37, arpejos e trechos de escalas para resolver na fundamental de F no compasso 41. 
No compasso 42 encontramos uma escala descendente que alcança a terça do próximo acorde, muito utilizada por Pixinguinha.

Nos próximos compassos, há a mesma estrutura de fundamentais e terças em tempo forte com algumas notas de passagem. No compasso 45 , o acorde de Bdim, bem definido pela tríade, seguido pela tríade de $D$ em direção à cadência final, sempre com fundamentais. A seguir temos um cromatismo de Sol - Sol\# para alcançar a primeira nota do compasso seguinte.

\section{Exemplo 11: Contraponto de Pagão, compassos 33 a 48}
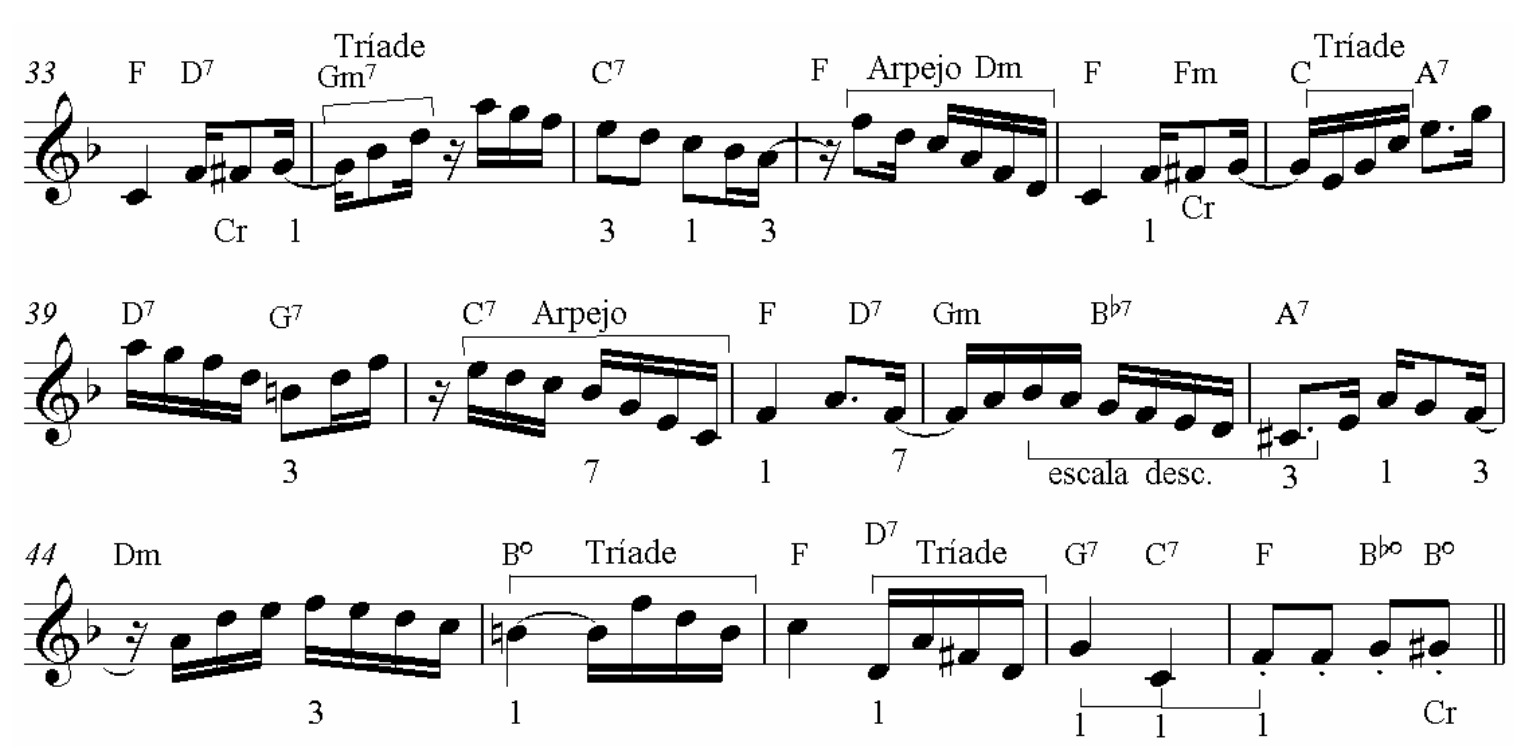

Parte B - segunda exposição (compassos 49 a 64)

Esta seção é praticamente igual a anterior: encontramos diversas fundamentais, terças e sétimas, além dos arpejos e tríades delineando a harmonia. No final, no compasso 63 , uma célula rítmica pontuada reforça os tempos fortes na fundamental e na terça. 
Exemplo 12: Contraponto de Pagão, compassos 49 a 64
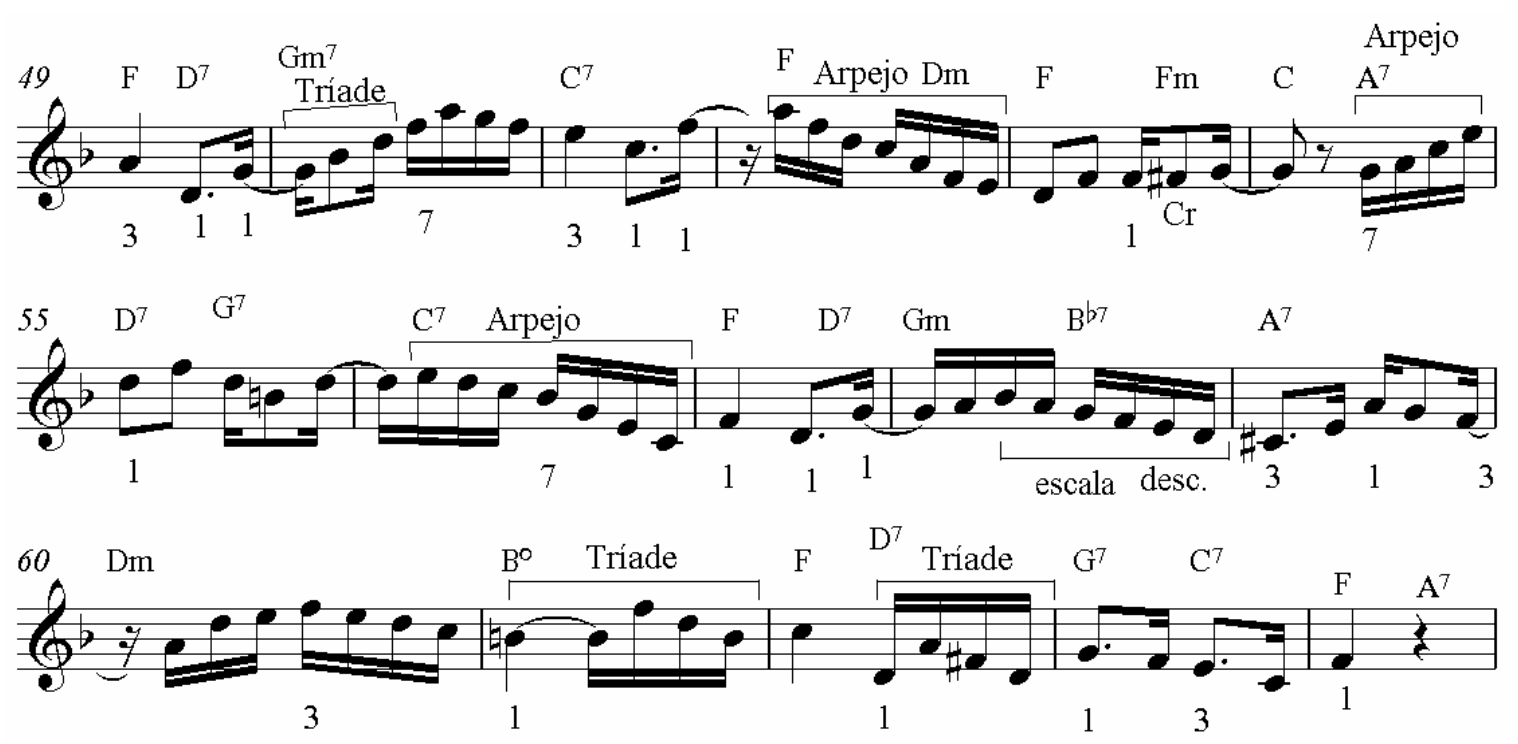

Parte A - Terceira exposição

Nesta reexposição da primeira parte o contraponto é praticamente o mesmo, portanto não será analisado.

Parte C - compassos 65 a 96

Esta seção está em D Maior, relativa do tom principal. Possui 32 compassos sem repetição. Inicia-se no compasso $65 \mathrm{com}$ a fundamental seguida por graus conjuntos para terça de D. Como no exemplo 9, podemos observar que nos compassos seguintes há uma construção melódica similar - um cromatismo descendente, formado pelas notas dos primeiros tempos dos compassos 71, 72 e 73, através dos arpejos, tríades e várias terças em tempo forte. Como acontece sempre na cadência final, Pixinguinha apresenta as fundamentais dos acordes definindo a harmonia. 
Exemplo 13: Contraponto de Pagão, compassos 65 a 80
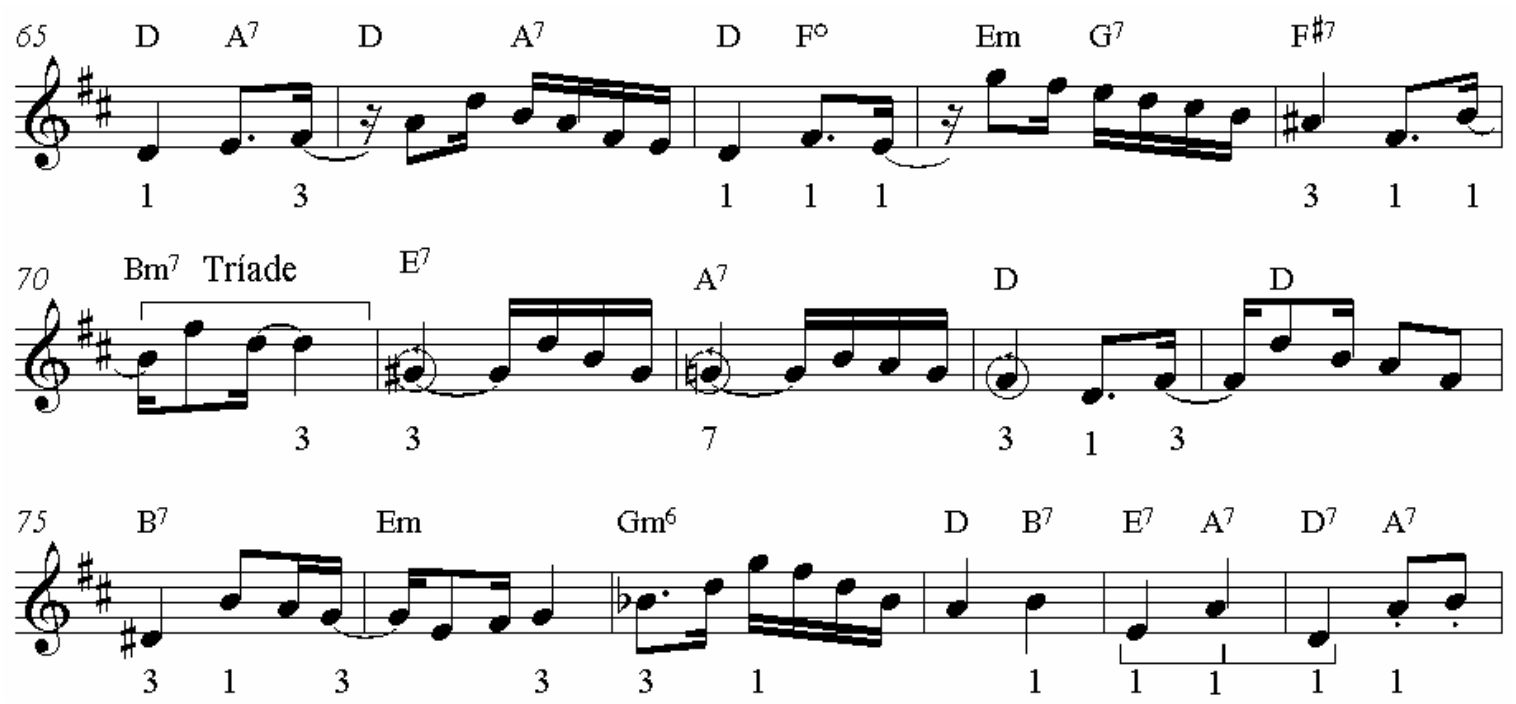

Seguindo com os próximos dezesseis compassos temos:

Nos dois primeiros compassos encontramos um motivo formado basicamente pelas fundamentais dos acordes, com um ritmo que nos remete ao som do agogô. No compasso 84 , uma resolução deste motivo sempre com as fundamentais em tempo forte.

Dos compassos 87 ao 89 são utilizadas as terças nos tempos fortes, com um arpejo de A7. No compasso 91 encontramos uma escala descendente que alcança a terça de B do compasso 92, recurso bastante utilizado por Pixinguinha. A partir daí encontramos tríade, terça e fundamentais.

Exemplo 14: Contraponto de Pagão, compassos 81 a 96
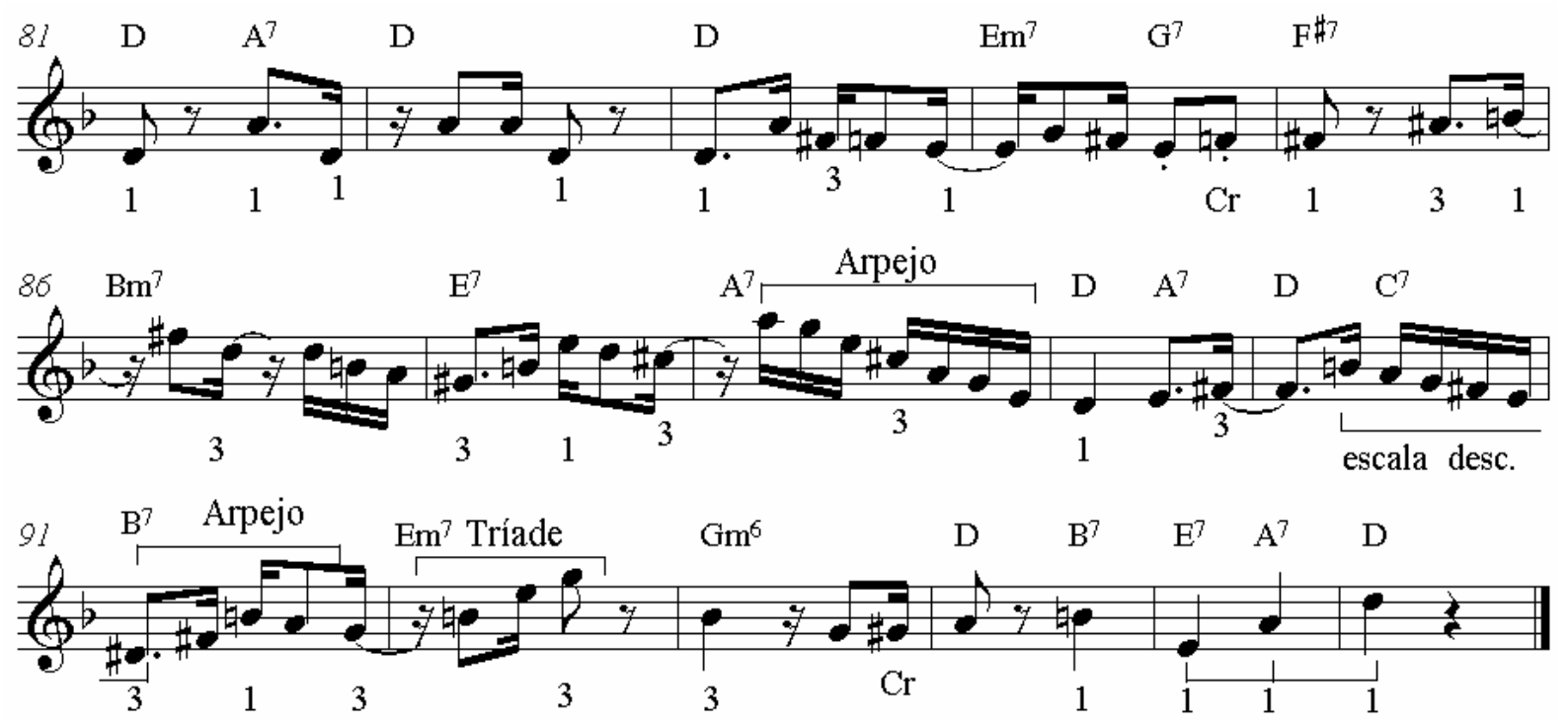

mesmo.

O último A também não será analisado, pois o contraponto é praticamente o

A seguir uma tabela com a contagem de fundamentais, terças e sétimas no tempo forte.

\begin{tabular}{|c|c|c|c|}
\hline Seções & Fundamental (1) & Terça (3) & Sétima (7) \\
\hline A1 & 12 & 7 & 3 \\
\hline A2 & 12 & 8 & 3 \\
\hline B1 & 10 & 6 & 2 \\
\hline B2 & 14 & 6 & 3 \\
\hline C & 29 & 21 & 1 \\
\hline
\end{tabular}

Tabela 2

\section{3 - Considerações finais}

Nos dois choros que analisamos, encontramos basicamente as mesmas características, ou seja, Pixinguinha utiliza-se amplamente de fundamentais, terças e sétimas nos tempos fortes, sempre com fundamentais ao final de cada seção.

Pixinguinha conduz sua melodia delineando toda a harmonia, isto é, a estrutura harmônica é claramente percebida através do desenho melódico de seu improviso, graças ao uso de vários arpejos e tríades. Outras características encontradas são os cromatismos que servem para se alcançar alguma nota do acorde, dando fluência à linha melódica. Quando existem acordes invertidos, muitas vezes eles são destacados na melodia para que fiquem claros. Encontramos raramente uma abordagem horizontal. No choro Um a Zero, encontramos abordagem horizontal em apenas três lugares. Três compassos na primeira parte, onde executa um trinado; no começo da segunda parte, onde repete frases que 
lembra a Aquarela do Brasil; e uma lembrança do tema na última apresentação da parte A.

No choro Pagão não observamos trechos em que Pixinguinha utilize uma abordagem horizontal, o que podemos notar são frases escalares descendentes, geralmente com a duração de um compasso, e que alcança a terça do acorde seguinte. Esse é um recurso muito utilizado pelos instrumentos graves que executam as "baixarias" no choro, e que Pixinguinha emprega várias vezes neste improviso.

No capítulo dedicado à improvisação vimos que a característica de uma abordagem vertical é a definição de cada acorde da música, projetando plenamente a identidade harmônica de cada acorde através da melodia, definindo os tipos de acorde na medida em que eles aparecem dentro do tema. Observamos claramente essas características em Pixinguinha, que sem se descuidar da condução melódica descreve a harmonia praticamente em todo improviso.

O autor utiliza praticamente em todos os tempos fortes notas essenciais para a identificação do acorde, ou seja, fundamentais, terças e sétimas. Utilizando os dados das tabelas anteriores, temos:

No choro 1 a 0 encontramos: $31,25 \%$ de fundamentais; $13,67 \%$ de terças e $7,03 \%$ de sétimas em tempo forte.

No choro Pagão encontramos: $40,10 \%$ de fundamentais; $25,00 \%$ de terças e $6,25 \%$ de sétimas em tempo forte.

Somados às outras características examinadas, podemos perceber que Pixinguinha utiliza em larga escala a abordagem vertical em seus improvisos. 


\section{CAPÍTULO IV}

\section{K- XIMBINHO: ENTRE O CHORO E O JAZZ}

\section{1) Apresentação ${ }^{33}$}

Sebastião de Barros, também conhecido como K- Ximbinho, nasceu em 20 de Janeiro de 1917, em Taipú, no Rio Grande no Norte, e faleceu em 26 de Junho de 1980, no Rio de Janeiro.

Logo na infância, K-Ximbinho manifestou interesse pela música. Em 1931, a família foi morar em Natal, onde ele estudou música com o professor Luis Soares. Nessa ocasião, matriculou-se em uma escola de música e, com amigos - todos apaixonados pelo jazz - fundaram o grupo Pan-Jazz, que tinha um repertório que incluía muitas músicas americanas da época.

Logo após sua saída do exército, em 1938, passou a integrar a Orquestra Tabajara, em João Pessoa, onde permaneceu até 1942. Nesta época, a Orquestra era dirigida por Olegário de Luna Freire. Depois da morte desse regente, Severino Araújo assumiu a direção da orquestra, que passou a se chamar Orquestra Tabajara de Severino Araújo.

Ainda em 1942, foi para o Rio de Janeiro e participou de diversas orquestras. No ano seguinte, atuou na Orquestra Fon-Fon e no mesmo ano na Orquestra de Napoleão Tavares. Apresentou-se em shows na boate Night and Day, retornando em 1945 para a Orquestra Tabajara como primeiro saxofonista.

A primeira composição gravada de K-Ximbinho foi Sonoroso, em parceria com Del Loro, interpretada pela Orquestra de Severino Araújo, em 1946. Sonoroso também foi gravada no mesmo ano por Ademilde Fonseca, acompanhada por Benedito Lacerda e seu conjunto. Em 1948, a música Sonhando, também em parceria com Del Loro, foi gravada pela Orquestra Tabajara e por Ademilde Fonseca, acompanhada por K-Ximbinho e seu conjunto.

\footnotetext{
${ }^{33}$ Todos os dados biográficos contidos neste capítulo foram tirados do Dicionário de Música do Rio Grande do Norte de Leide Câmara: contém a memória da Música Potiguar com 600 verbetes de músicos catalogados, com discografia e musicografia, e algumas informações baseadas em entrevista com sua filha Gilka Barros.
} 
Em 1948, K-Ximbinho tocou na Orquestra da Rádio São Paulo e, em 1951, na Rádio Nacional. Nesse mesmo ano, iniciou um curso de harmonia e contraponto com Hans J. Koellreutter que durou aproximadamente três anos. Em 1954 embarcou em turnê para a Itália, a bordo do navio Provance, onde atuou como instrumentista. No ano seguinte, de volta ao Brasil, trabalhou como arranjador da gravadora Odeon e, em 1959, da gravadora Polydor. K-Ximbinho sempre tocou na noite, em clubes, boates e bares. Segundo sua filha Gilka ${ }^{34}$ a boate Sachas foi o lugar onde trabalhou grande parte de sua vida profissional. Essa boate era freqüentada pelo público amante da música americana, principalmente do jazz: "Ele gostava de jazz, e dizia que à noite ele podia tocar mais livremente. O gosto pelo jazz veio da época de jovem, em Natal, onde foi educado. Foi nesta época que ganhou o apelido de KXimbinho, por conta do instrumento que tocava (saxofone), que tem a forma de um cachimbo". Gilka ainda comenta que seu pai era muito estudioso e gostava de fazer os cursos por correspondência da Berklee $S c h o o l^{35}$ e que pouco antes de ficar doente, por volta dos anos 80 , ele estava concluindo um curso de contraponto e fuga.

De 1965 a 1975, integrou o conjunto Sete de Ouro, liderado pelo Maestro Cipó. Nesta época, foi também orquestrador da TV Globo e fez parte da Orquestra Sinfônica da Rádio Nacional.

Em 1970, venceu o Festival Nacional do Choro, da Rede Bandeirantes de Televisão, com a música Manda Brasa. Continuou atuando em várias orquestras e em grupos menores na noite, e era comum acompanhar vários cantores da rádio Nacional, como por exemplo: Cauby Peixoto, Ângela Maria, Emilinha Borba, Marlene entre outros.

Em 1980, a Gravadora Eldorado lançou o LP Saudades de um Clarinete, que foi seu último trabalho de gravação, contendo 12 choros de sua autoria. Esse trabalho pode ser considerado um bom exemplo de sua versatilidade, pois nele atua como compositor, instrumentista, arranjador e regente. Esse disco representa uma síntese de sua carreira, pois nele percebemos claramente a fusão das linguagens do choro e do jazz, característica marcante de sua obra.

\footnotetext{
${ }^{34}$ Em entrevista informal concedida à autora, por e-mail no dia 25/05/2008.

${ }^{35}$ Berklee School - Fundada em1945, em Boston; com objetivo de proporcionar treinamento formal em jazz, rock e outros gêneros populares.
} 
Um exemplo dessa fusão aparece nos arranjos. Em algumas faixas encontramos uma formação de bigbands, e em outras um regional típico do choro tradicional, revelando uma integração dos universos musicais.

Outra importante qualidade de K-Ximbinho é a liberdade de interpretação, sempre variando a maneira de tocar, não se fixando totalmente na partitura escrita.

Em entrevista concedida a Paulo Moura diz:

Eu gosto do chorista que apresenta em primeiro lugar a melodia, mas dentro dessa apresentação, mesmo na primeira vez, mesmo dentro da melodia pura, ele demonstre um pouco de colorido, um pouco de bossa, que apenas não ficasse tão restrito à execução melódica do choro... (encarte do CD saudades de um clarinete,1980).

Outra característica que pode ser considerada inovadora aparece na redução da forma do choro para apenas duas partes, e não três como a forma tradicional dos choros. Ele achava suficiente apenas duas partes para demonstrar o conteúdo melódico do choro oferecendo maior espaço para improvisações. Vale lembrar que ele não foi o primeiro a compor choros com duas partes apenas, contudo a liberdade de improvisar sobre a harmonia de uma das partes, nos moldes do jazz, foi uma inovação pessoal.

Sobre esse assunto, ainda nessa entrevista ele comenta:

É menos tempo, menos enfadonho, porque três partes é o choro característico brasileiro dos bandolins... isso ainda existe hoje, mas... desde que iniciaram a apresentação de chorinho, parece que, talvez obrigatoriamente, o choro tinha que apresentar três seções. Hoje eu acho que é desnecessário tudo isso; em duas seções você mostra o conteúdo melódico de uma composição popular como é o chorinho, e acho que na primeira seção a melodia já fica explicada, estabelecida, esclarecida... isso é uma maneira de pensar... (1980).

K-Ximbinho dava especial importância à improvisação dentro de sua música. Em linhas gerais, a improvisação proposta por ele integra os universos do jazz e do choro. No choro tradicional, a improvisação era sempre uma variação rítmicomelódica do tema, já na música americana sempre existiu maior liberdade de se afastar do tema proposto, baseando-se principalmente na seqüência harmônica sugerida pelo tema. Neste trecho de sua entrevista, ele revela sua preferência:

Eu acho que nesse caso, aproveitaria bem as duas partes com uma modulação para que ela ficasse mais, estendesse mais, a fim de completar o tempo ou improviso... improviso é muito necessário, e no chorinho é lindo, e que antigamente não havia e hoje está aos poucos surgindo com vários chorões. 


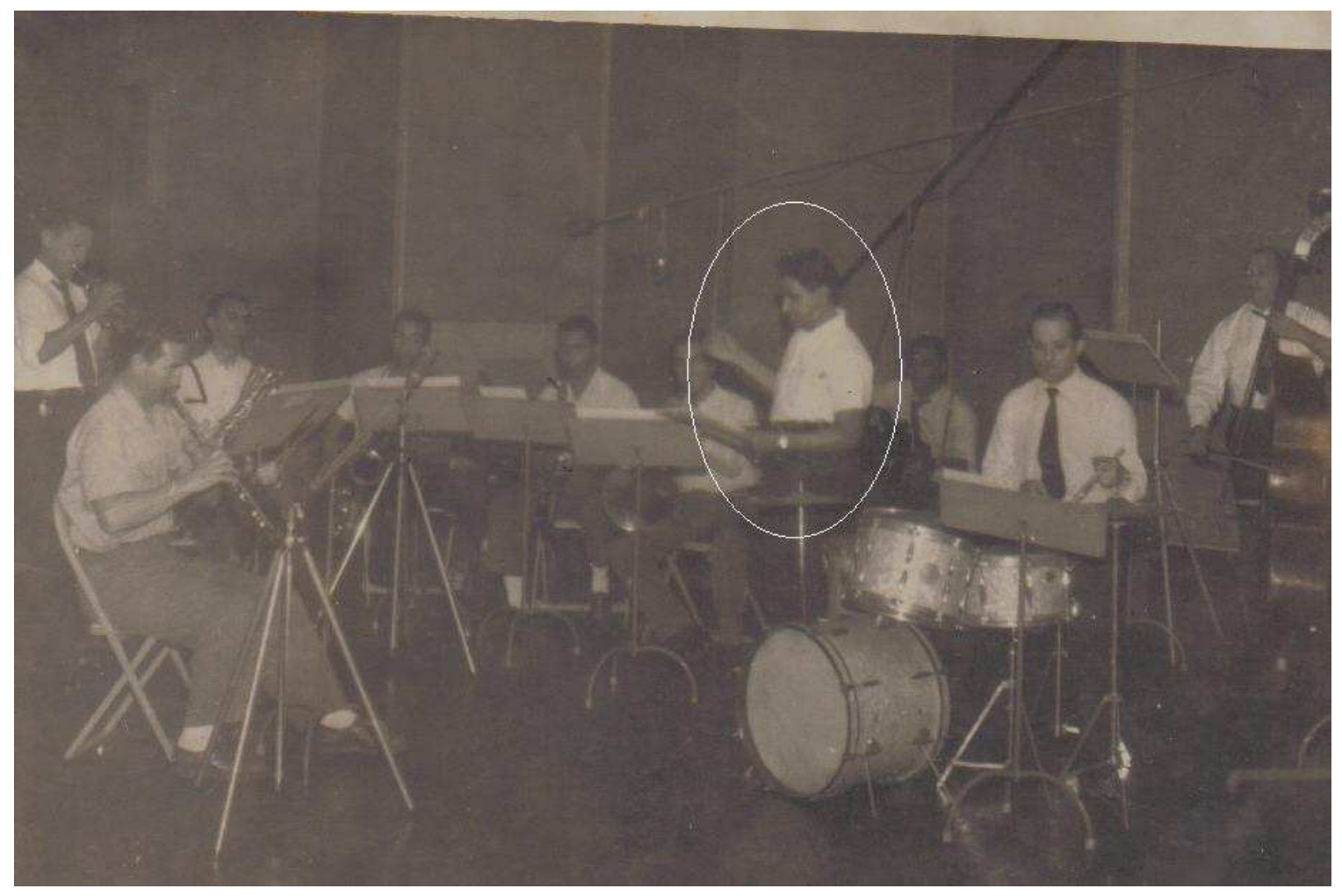

K-Ximbinho regendo seu "tenteto" formado em 1959. (Fotografia cedida por sua filha Gilka Barros)

As influências do jazz são claramente notadas em suas gravações. Ele mistura estes elementos com os brasileiros para formar um estilo pessoal. Podemos ouvir em suas interpretações que estas influências são claramente reveladas em sua sonoridade, em seu modo de articulação e inflexão, como também no fraseado. Mesmo assim ele declara nessa entrevista a Paulo Moura que não acha que suas linhas melódicas tenham influência jazzística. E completa:

...música vem sendo desenvolvida à proporção em que os anos passam, assim a linha melódica atualiza-se. Há choros atuais em que a melodia, eu acho, está de acordo com a época em que vivemos, em que escutamos melodias internacionais.

K-Ximbinho era sem dúvida um grande admirador do jazz, e durante toda sua carreira se apresentou em boates e bares, lugar onde the era permitido criar mais livremente através dos seus improvisos. Cazes (1998) acredita que K-Ximbinho realizou um casamento perfeito entre o choro e os elementos harmônicos oriundos do jazz, e continua: 
Joachim Koellreutter. Compondo choros que por vezes sugeriam acompanhamentos tipo bossa nova...(p. 118)

Em seu site, Paulo Moura, clarinetista e saxofonista, e também seu grande admirador reforça essa idéia:

Pouca gente sabe, mas ele é um dos precursores da bossa nova, assim como João Donato e Johnny Alf, pois fazia essa mistura de música brasileira com jazz, antes dos anos 50.(www.paulomoura.com)

O material de pesquisa da vida de K-Ximbinho é muito pequeno, por isso não faremos uma divisão de sua biografia em fases, como fizemos com Pixinguinha, cuja vida e obra é amplamente documentada.

Nos discos gravados que tivemos acesso, a improvisação quase sempre se limitava a introduções, finais ou pequenos trechos executados junto ao cantor que ele acompanhava. Nos seus discos solo, muitas vezes K-Ximbinho expunha o tema e, como o improviso era feito em uma parte apenas (geralmente na primeira), quase sempre quem executava era outro instrumentista. Nas gravações com a Orquestra Tabajara também não se ouve improvisações, provavelmente não era o que acontecia quando tocavam ao vivo, uma vez que nessas ocasiões havia maior liberdade no que tange o tempo de duração das músicas, o que em gravações sempre foi limitado. 


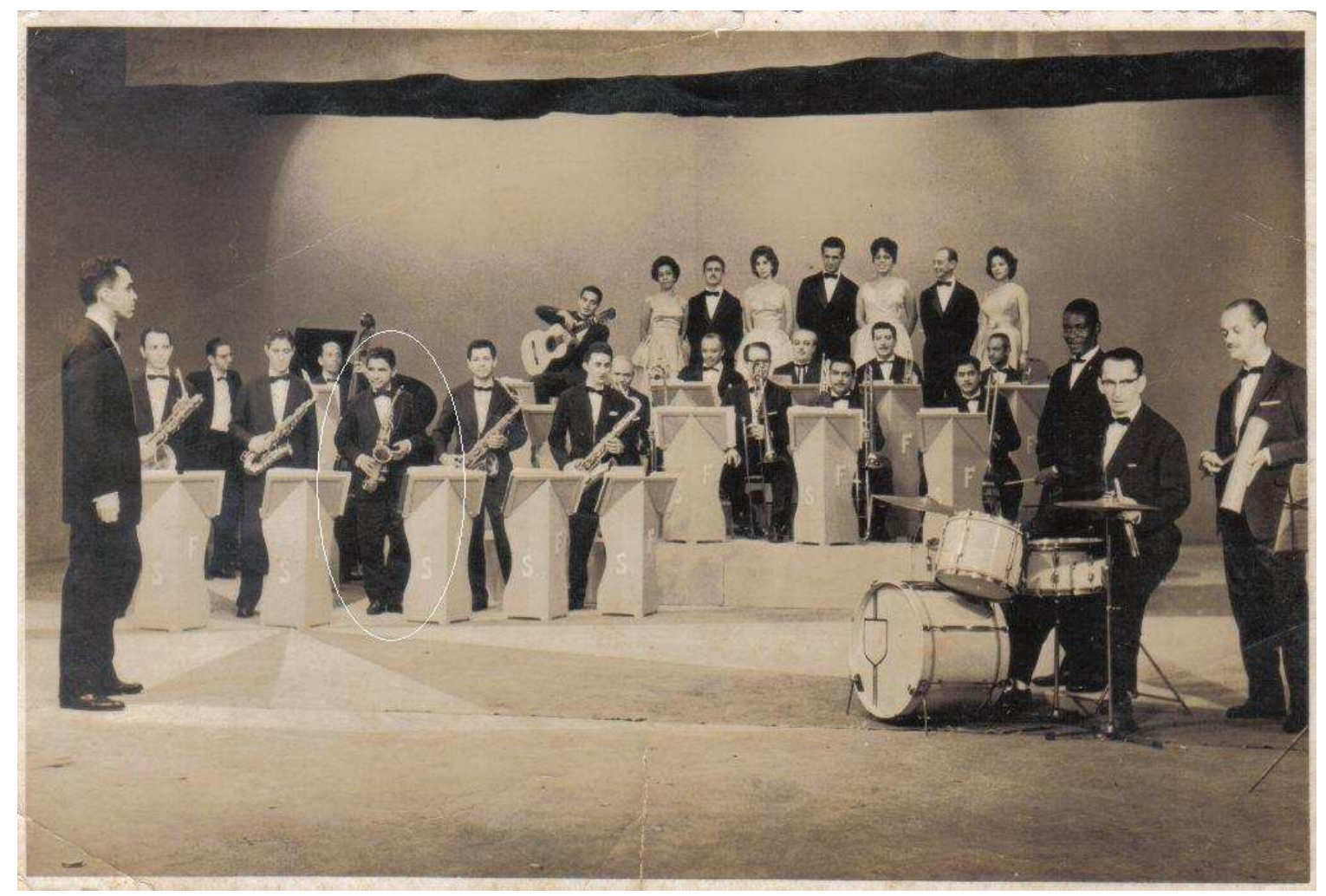

K-Ximbinho com a Orquestra do maestro Severino Filho. (foto cedida por sua filha Gilka Barros)

\section{2 - Análises dos improvisos}

A princípio selecionamos dois choros, que foram gravados por K-Ximbinho em 1980 em seu último disco, pouco antes de falecer, em 1981.

O disco Saudades de um clarinete, gravado pelo selo Eldorado, contém apenas músicas de sua autoria, em sua maioria choros. A regência, os arranjos e algumas interpretações ao clarinete também são suas. Algumas faixas são executadas por uma formação semelhantes à das bigbands com dois sax-alto, dois sax-tenor, um sax-barítono, um trombone e um trompete, acompanhados por piano, baixo e bateria; e outras por um grupo típico regional com cavaquinho, violão, violão de sete cordas, pandeiro e clarinete ou saxofone. Uma das faixas é executada pelo Quinteto Villa-Lobos, composto por flauta, oboé, clarinete, fagote e trompa.

Os dois primeiros choros que vamos analisar são Velhos Companheiros e Sempre, ambos de sua autoria. Apesar do interesse do nosso trabalho ser a improvisação, achamos conveniente analisar, mesmo que de maneira sucinta, os temas, observando os aspectos melódicos, harmônicos, rítmicos e interpretativos relevantes sobre os quais se deu essa improvisação. 
Usaremos para a análise deste autor a relação entre a escala e o arpejo, além de examinar os motivos melódicos que ele desenvolve durante o improviso. Utilizaremos como complemento a análise do improviso sobre o tema Lá vem a baiana, de Dorival Caymmi, gravada por K-Ximbinho em 1958 no disco Em ritmo de dança vol.3. Apesar de não se tratar de um choro, revela de maneira clara as principais características que queremos ressaltar nas construções dos improvisos de K-Ximbinho. Neste caso, como ele não é o compositor do tema, só analisaremos o improviso.

\subsubsection{Velhos Companheiros - Tema}

Neste choro observamos uma seção $A$ de dezesseis compassos, composta por duas frases ${ }^{36}$ denominadas $A$ e $B$, de oito compassos cada uma. No compasso 17 há uma repetição da primeira frase que vai até o compasso 23 que analisamos como $A^{\prime}$, pois é praticamente igual à primeira parte com exceção da última nota da frase, que é meio tom acima. Os últimos oito compassos - 24 a 32- podem ser considerados uma frase-coda, onde percebemos elementos das frases $A$ e $B$ dirigindo-se à tonalidade principal. Desse modo o choro tem apenas uma parte - 0 que pode ser considerado uma inovação, visto que tradicionalmente o choro é composto de três partes.

Uma das principais características dos choros de K- Ximbinho é possuírem geralmente apenas duas partes, segundo ele isso daria um espaço maior para a improvisação.

\section{Considerações melódicas:}

Observamos uma frase que chamaremos de A dos compassos 1 a 8 . Nessa frase encontramos motivos ${ }^{37}$ que aparecerão no decorrer do tema. São eles:

\footnotetext{
${ }^{36}$ Utilizamos o termo frase baseado no livro fundamentos da composição musical, onde Schoenberg diz: "O termo frase significa, do ponto de vista da estrutura, uma unidade aproximada àquilo que se pode cantar em um só fôlego. Seu final sugere uma forma de pontuação, tal como uma vírgula".

${ }^{37}$ O termo "motivo" utilizado aqui é definido por Schoenberg: "Até mesmo a escrita de frases simples envolve a invenção e o uso de motivos, mesmo que, talvez, inconscientemente. Usado de maneira consciente, o motivo deve produzir unidade, afinidade, coerência, lógica, compreensibilidade e fluência de discurso. O motivo geralmente aparece de uma maneira marcante e característica ao início da peça. Os fatores constitutivos de um motivo são intervalares e rítmicos [...] o motivo básico é freqüentemente considerado o "germe"da idéia[...]
} 
No compasso 1 chamaremos de motivo 1 o que está no primeiro tempo, e de motivo 2 o que se encontra no segundo tempo.

Nos compassos 2 e 3 observamos um motivo que chamaremos de 3 , de caráter escalar e descendente que parte da quinta do acorde $(\mathrm{Gm})$ e chega até a quinta do acorde seguinte (F7). Este motivo se repete nos compassos 4/5, 6/7 e se estabiliza no compasso 8.

\section{Exemplo 1: Velhos Companheiros-tema, compassos 1 a 8}

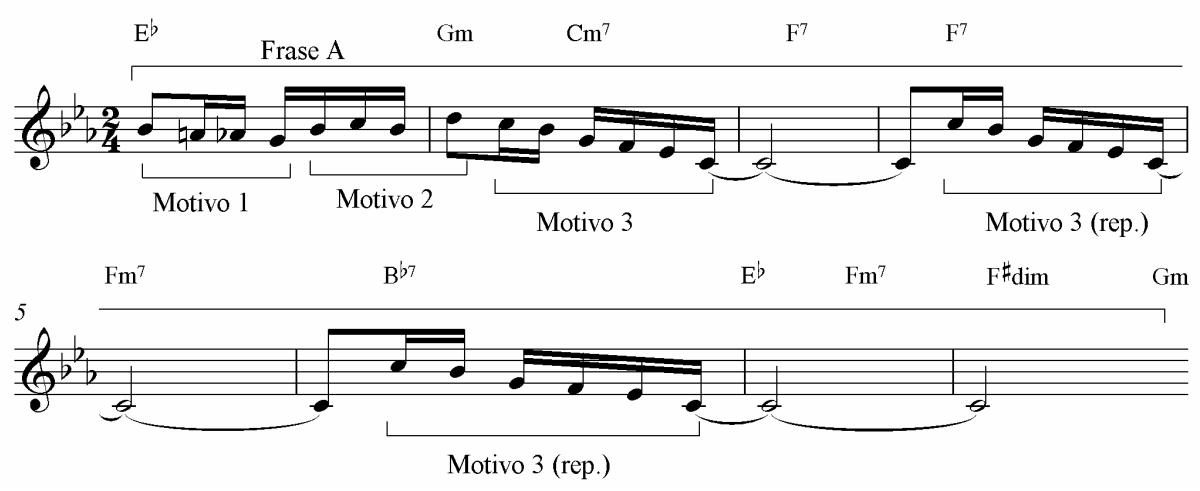

Do compasso 9 ao $16 \mathrm{~K}$-Ximbinho utiliza a frase $\mathrm{B}$ composta por uma seqüência escalar ascendente que resolve no que chamaremos de motivo 4 (formado por uma sexta maior descendente), este motivo se repetirá no compasso 13 (com um intervalo de terça menor) com deslocamento rítmico, e no primeiro tempo do compasso 15 (com intervalo de segunda menor). Este período se completa no compasso $16 \mathrm{com}$ um acorde de $\mathrm{Bb} 7$ repousando na quinta aumentada (\#5) do acorde de Bb7. 
Exemplo 2: Velhos Companheiros-tema, compassos 9 a 16

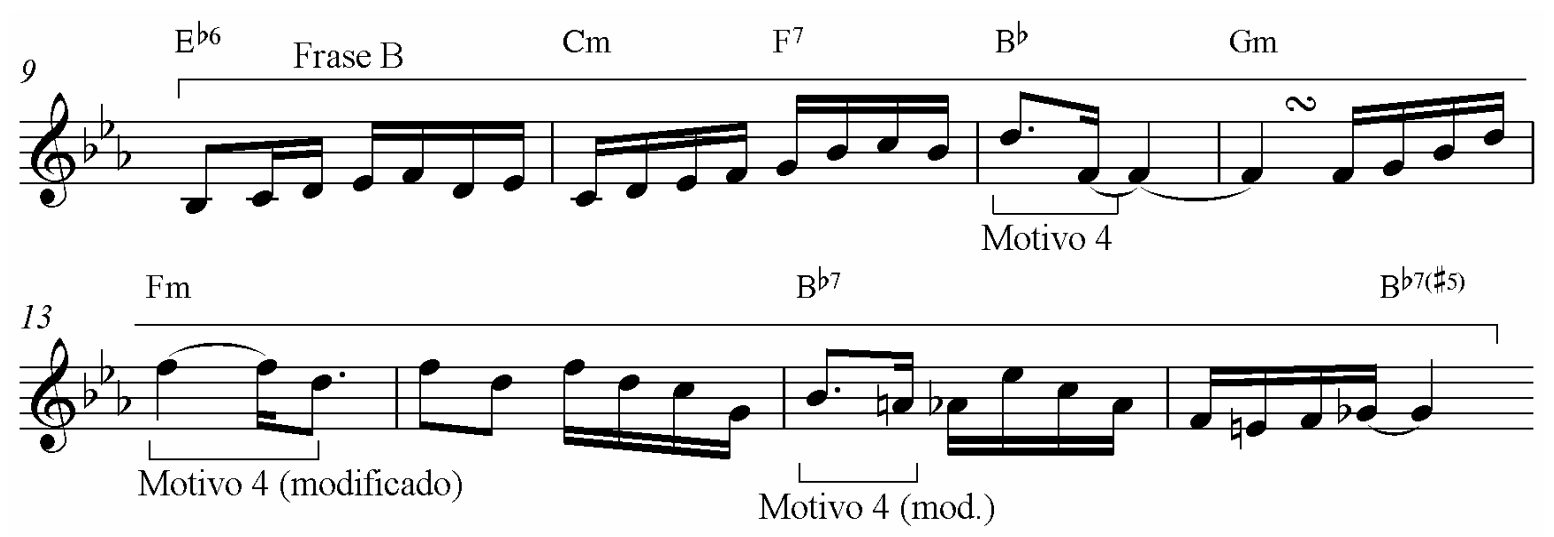

Do compasso 17 ao 23 (seção A') há uma repetição da frase $A$, apenas com terminação diferente no compasso 23. Chamaremos esta nota final de ajuste harmônico porque repousa meio tom acima $(\mathrm{em} \mathrm{Db})$ para se adequar à harmonia que é diferente.

Exemplo 3: Velhos Companheiros - tema, compassos 17 a 23

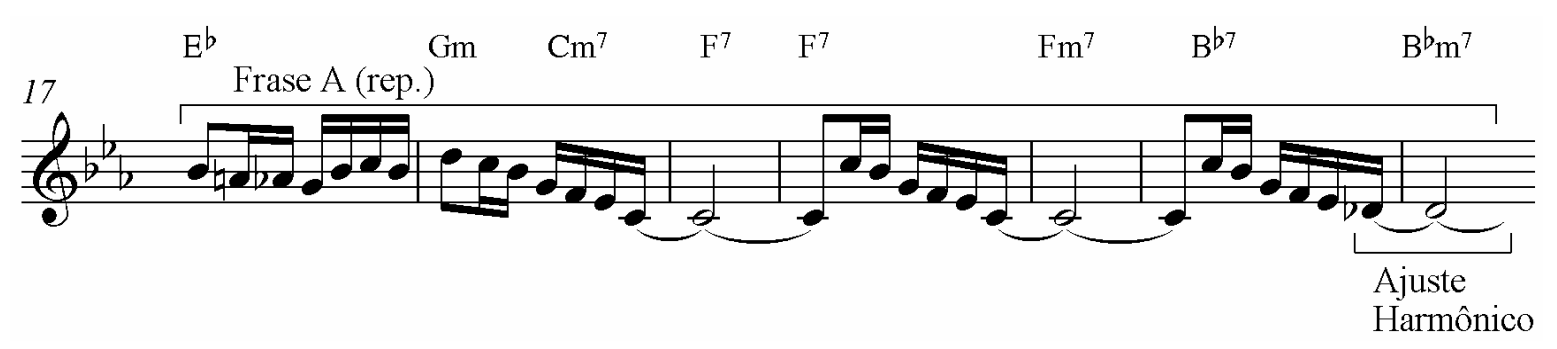

O trecho a partir do compasso 24 até o final denominamos de frase-coda com elementos das duas frases. No compasso 24 temos o motivo 3 modificado se dirigindo por arpejo para o compasso 25 onde há o motivo 4 ampliado para um intervalo de oitavas .

No compasso 27 encontramos novamente o motivo 3 abreviado seguido do motivo 2 modificado no final (meio tom abaixo).

No compasso 28, o autor apresenta o mesmo desenho rítmico (pontuado) que chamamos de motivo 4 originalmente com sexta, agora apresentado com uma segunda, reforçando a extensão da harmonia - a nona menor (b9).

Nos últimos compassos - 29 e 30 - há fragmentos de escalas finalizando com um arpejo na dominante que resolve na tonalidade principal. 
Exemplo 4: Velhos Companheiros - tema, compassos 24 a 32
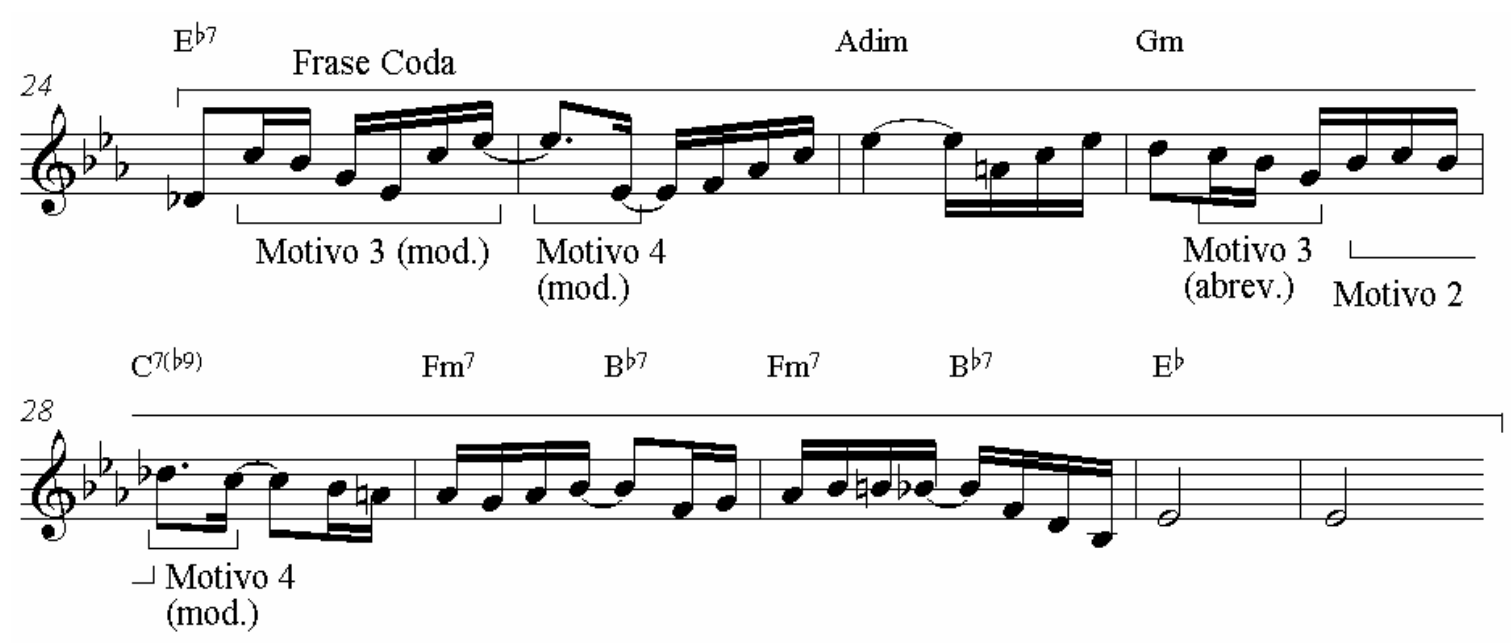

Considerações harmônicas:

O tema está na tonalidade de Eb a única diferença que notamos acontece na repetição do $A$, que começa no compasso 17; podemos observar que ao final da frase $\mathrm{A}$ há a modulação, no compasso 23 , que segue para a dominante menor (Bbm7), depois para Eb7 e resolve temporariamente em Ab (II-V-I). Retorna ao tom principal passando por Adim - Gm - C7b9 (II- V de Fm) e segue com uma cadência II -V para o tom principal - Eb.

Considerações rítmicas:

Quanto ao aspecto rítmico, a maioria das células analisadas é típica do choro (semicolcheias, síncopas e colcheias pontuadas com semicolcheias - ex: 17), sem muitas variações, exceto nos compasso 13 e 14 onde notamos um tipo de deslocamento rítmico.

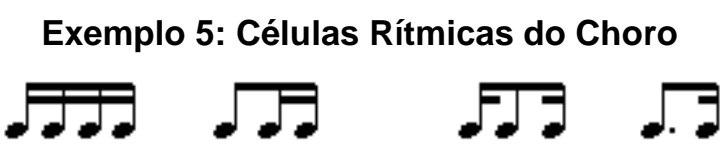

Considerações interpretativas:

O principal diferencial que encontramos neste tema está presente nos aspectos interpretativos e certamente serão melhor compreendidos através da audição das gravações. Através dos registros sonoros podem-se perceber as 
inflexões, articulações e ornamentos. Listaremos o que nos parece mais significativo para a nossa análise.

Em primeiro lugar, o intérprete executa as semicolcheias sempre com intenção "jazzista", ou seja, com uma intenção próxima à tercinas, como se o compasso fosse composto (12/8).

Escreve-se:

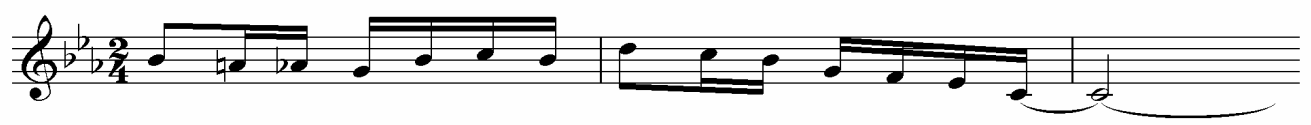

Executa-se aproximadamente:

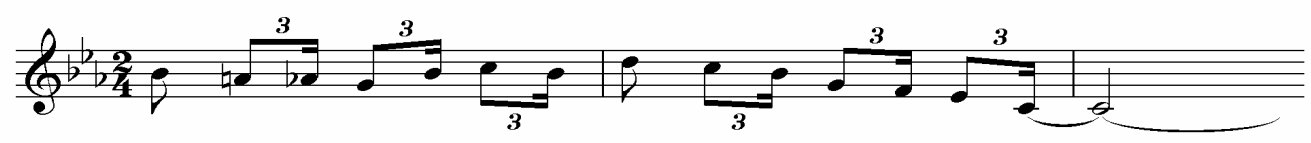

As articulações também são executadas com leve acento na parte fraca do tempo, como no jazz. No compasso 9 ouvimos um glissando descendente. No compasso 12, um mordente e, nos compassos 13 e 14, as notas são destacadas com um ligeiro bend ${ }^{38}$.

\subsubsection{Velhos Companheiros - Improviso}

Depois de analisarmos alguns aspectos do tema, passaremos ao nosso assunto principal, a improvisação propriamente dita. Como fizemos anteriormente quando analisamos o tema, examinaremos os aspectos melódicos, harmônicos, rítmicos e interpretativos separadamente.

De maneira similar ao tema, consideraremos as frases de oito compassos cada: frase $A$ do compasso 1 ao 8 , frase $B$ do compasso 9 ao 16, uma frase $C$ (pois

${ }^{38}$ Bend (pitch bend): recurso expressivo usado no saxofone, uma espécie de portamento do jazz; ataca-se a nota um pouco abaixo da sua afinação real até chegar na afinação correta. 
não existe repetição) que chega ao compasso 24 e uma frase-coda nos últimos oito compassos.

Considerações melódicas:

No compasso 1 encontramos dois arpejos: um no primeiro tempo, do próprio acorde de Eb com sexta e no tempo seguinte um arpejo sobreposto,do II grau Fm também com sexta. Essa sobreposição enfatiza as extensões do acorde de Eb (6-911-13).

Nos compassos seguintes observamos seqüências formadas por notas do acorde e algumas notas de passagem.

Dentro de um acorde de $\mathrm{Bb} 7$ no compasso 6, encontramos no tempo forte um Mi natural que pode ser considerado uma apogiatura ou aproximação cromática da quinta que determina um intervalo de quarta aumentada com a fundamental.

Nos compassos 7 e 8 continuamos com melodias baseadas em arpejos, sempre com notas do acorde. No segundo tempo do compasso 8 encontramos uma figura rítmica de fusa que pode ser considerado um mordente.

\section{Exemplo 6: Velhos Companheiros-improviso, compassos 1 a 8}
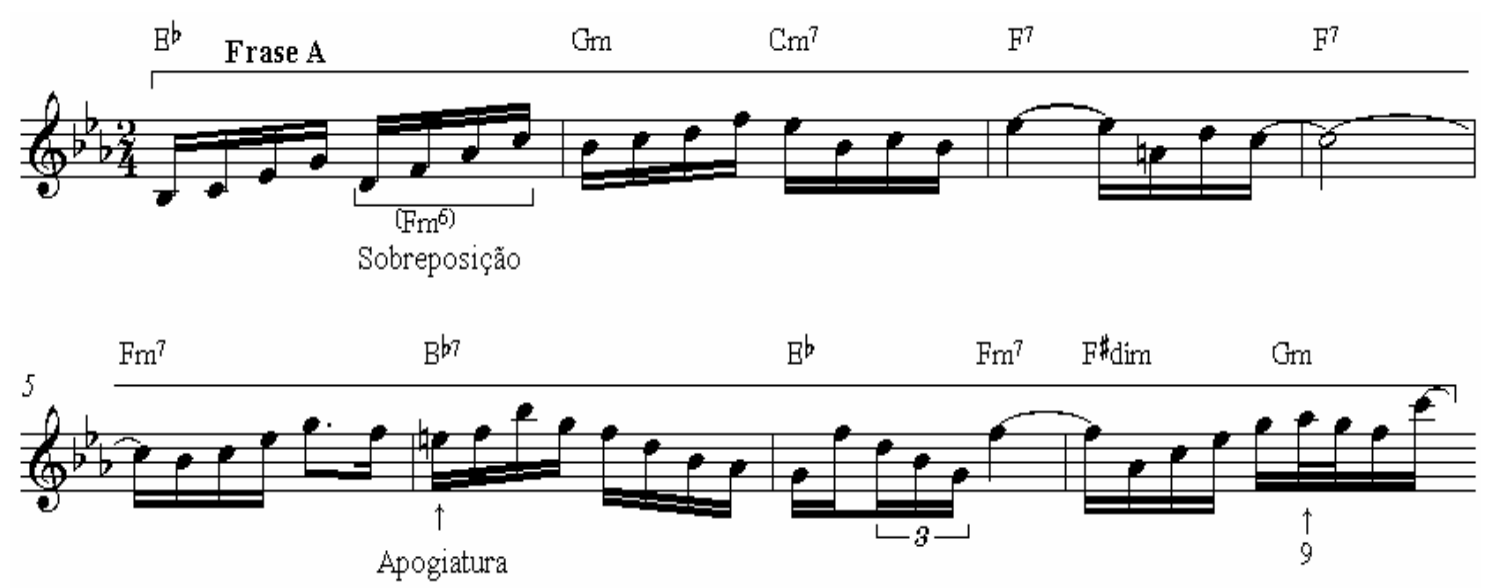

No início deste improviso K-Ximbinho revela principalmente características verticais, com a maioria das frases baseadas em arpejos, alguns deles sobrepostos contribuindo para enfatizar algumas extensões do acorde. 
O autor inicia o compasso 9 com uma nova frase que chamaremos de $B$ que coincide com a frase B do tema. Essa frase é formada por uma nota longa que é a sexta do acorde de Eb, seguida por arpejos descendentes no compasso 10. Neste mesmo compasso, no segundo tempo, observamos novamente uma sobreposição de harmonia, pois o arpejo se constrói sobre o acorde de $\mathrm{Gm}$ e não sobre a harmonia (F7); alcança-se a sétima através de um cromatismo Sol-Solb-Fa. Dentro do acorde de Cm consideramos esse cromatismo (Solb) uma blue note ${ }^{39}$.

Prosseguindo, no compasso 11 encontramos dentro de um acorde de $\mathrm{Bb}$, a terça menor e em seguida a quarta aumentada, sempre retornando à nota fundamental Sib. Essa idéia é claramente construída sobre uma escala blues, e revela uma característica jazzística do improviso, como a blue note comentada anteriormente.

No compasso 12 temos arpejos do acorde que chegam até a fundamental do compasso seguinte.

Observamos segmentos escalares no compasso 14, com uma descida cromática da sétima maior para sétima menor - característica da escala bebop ${ }^{40}$. Nos compassos 15 e 16 há dois grupetos que tem como base a nota Sib, o primeiro antecedendo a terça (Ré) e o segundo a quinta (Fa) do acorde de $\mathrm{Bb}$.

\section{Exemplo 7: Velhos Companheiros - improviso, compassos 9 a 16}
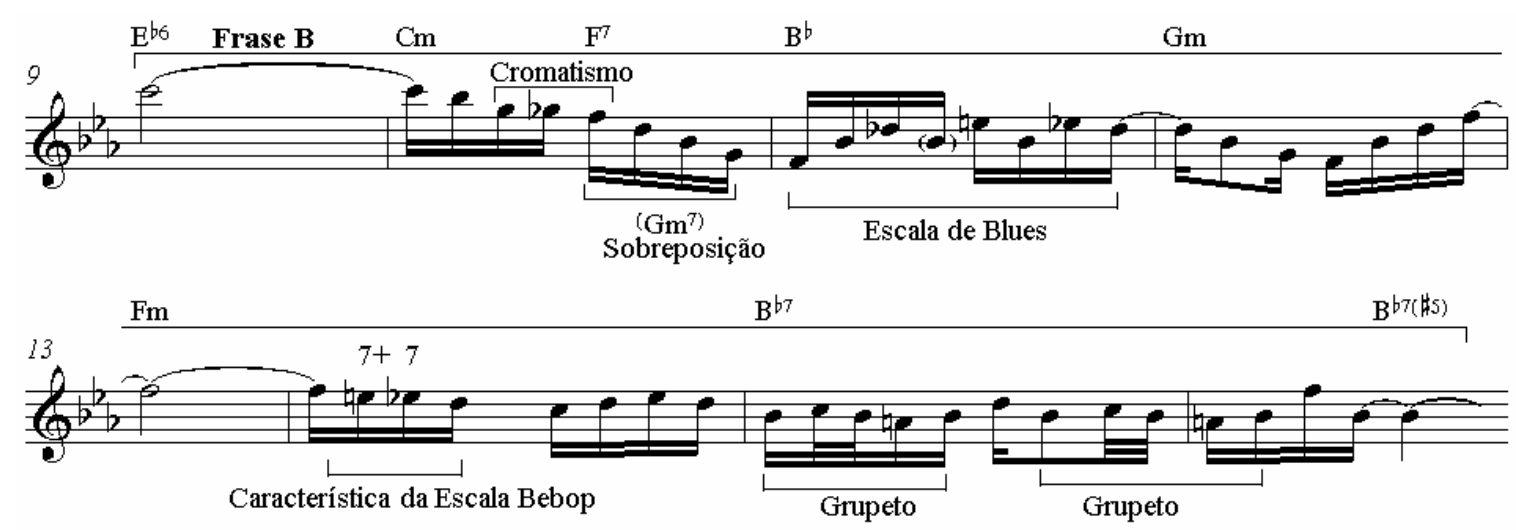

\footnotetext{
${ }^{39}$ Blue note: Notas que não estão presentes na escala diatônica tradicional, pertencem à escala blues como a terça menor e a quarta aumentada.

${ }^{40}$ O Bebop representa uma importante corrente do Jazz, estilo praticado a partir da primeira metade da década de 40 , privilegia os pequenos conjuntos e os solistas de grande virtuosismo, com fraseados flexíveis e andamentos rápidos que exigem uma técnica instrumental muito desenvolvida. A escala Bebop dominante possui os seguintes intervalos: 123456 b7 78.
} 
Este trecho já nos permite observar a importância das linhas horizontais na construção das frases de K-Ximbinho, o autor utiliza em três momentos notas características da escala blues e bebop, por meio de cromatismos e também desenhos de grupetos.

A seguir inicia-se o que denominamos frase $C$, nos compassos 17 e 18 onde surge mais uma frase comum na linguagem do jazz, alternando-se aproximações cromáticas inferiores e aproximações diatônicas superiores. No compasso 17 em Eb há uma aproximação de nona, de quinta e de fundamental e no compasso seguinte - aproximação de fundamental e de terça em Gm, e no segundo tempo de terça em $\mathrm{Cm}$. A seguir uma célula rítmica sincopada terminando com um salto de oitava nos compassos 19 e 20.

Encontramos nos compassos 21 e 22 uma frase descendente Sib - La - Sol - Fa - Mi - Re - Do - Sib, que resolve no primeiro tempo do compasso 23, descrita através das notas agudas e complementadas por notas do acorde.

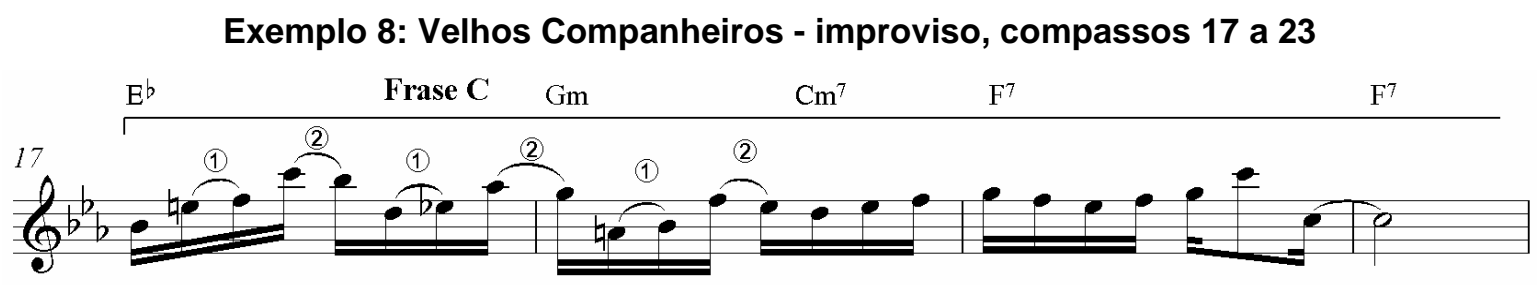

(1) Aproximação cromática inferior

(2) Aproximação diatônica superior

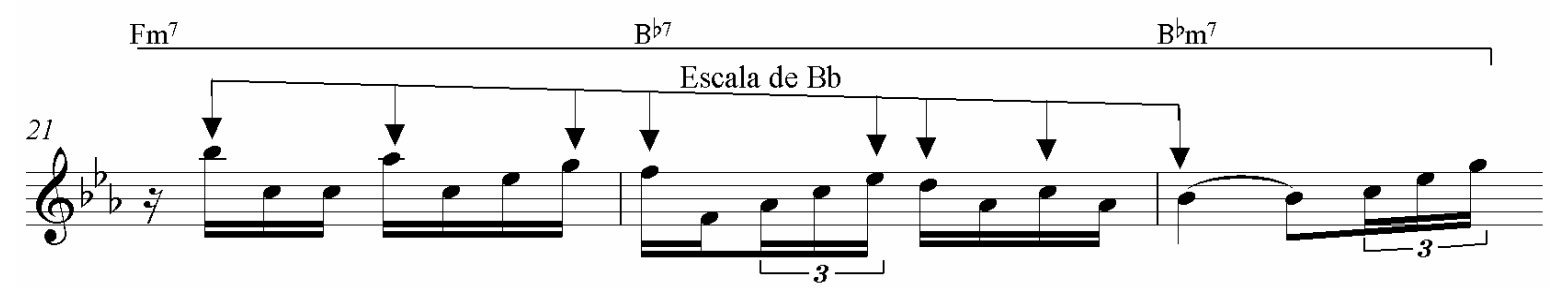

Neste exemplo nota-se uma abordagem horizontal em todo o trecho por meio de frases mais longas com características "jazzísticas", preponderância de escalas e ênfase ao campo tonal sem preocupação com a definição dos acordes por compasso.

Denominamos de frase-coda os oito últimos compassos do chorus. Essa frase inicia-se com um trecho da escala de Eb, em seguida ouvimos arpejos baseados 
nas notas do acorde, e no compasso 29 um grupeto, que ocorreu anteriormente no compasso 15.

No dois últimos compassos temos uma cadência II - V - I, que resolve na fundamental principal.

Exemplo 9: Velhos Companheiros - improviso, compassos 24 a 32
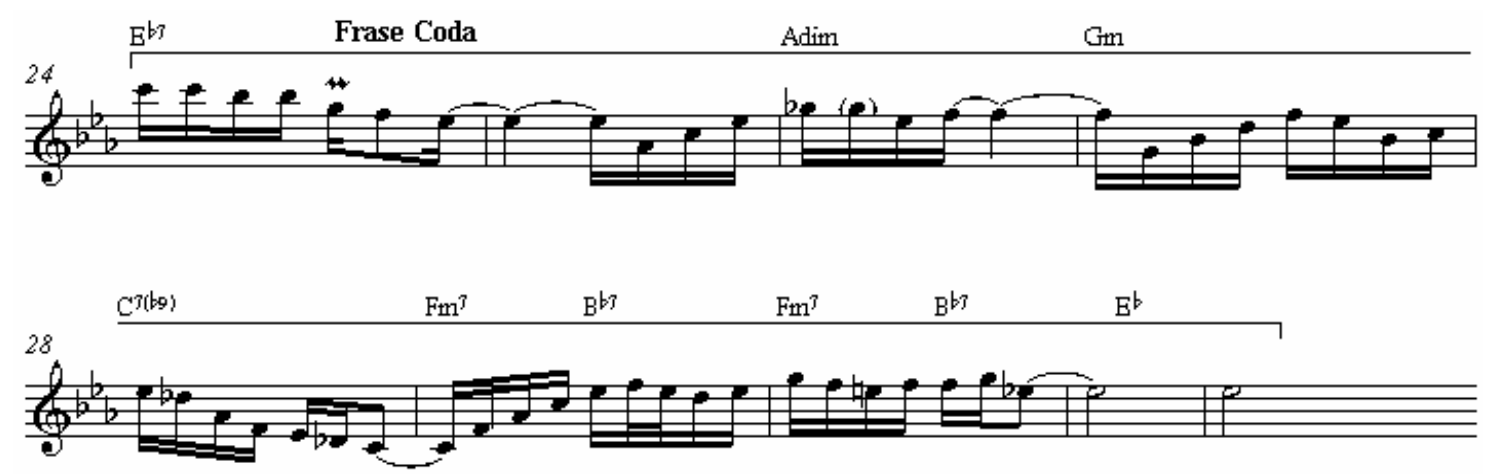

Neste final nota-se uma mistura das duas abordagens sem destaque especial para uma delas, pois há segmentos escalares no início e no final, no meio, porém, observamos diversos arpejos que definem o caminho harmônico.

Considerações rítmicas:

No improviso, K-Ximbinho segue com a mesma tendência rítmica jazzística executada no tema, ou seja, com as semicolcheias tercinadas (como explicamos anteriormente).

Em relação a esse aspecto, observamos algumas importantes inovações: além das células rítmicas básicas do choro, ou seja, as semicolcheias, síncopas e colcheias pontuadas com semicolcheias, encontramos algumas mais complexas. Por exemplo, no primeiro tempo do compasso 7, dentro de um arpejo de Eb, temos duas semicolcheias e uma tercina de semicolcheias.

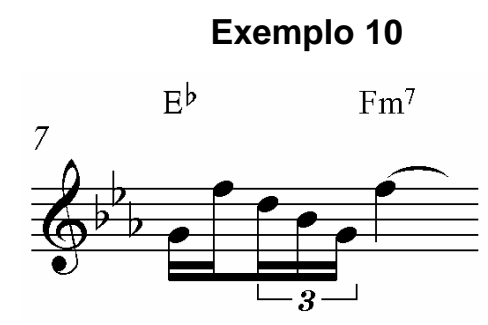


No compasso 8 é a primeira vez que aparecem fusas, este ritmo se repetirá mais duas vezes, no início do compasso 15 e no compasso 29.

\section{Exemplo 11}
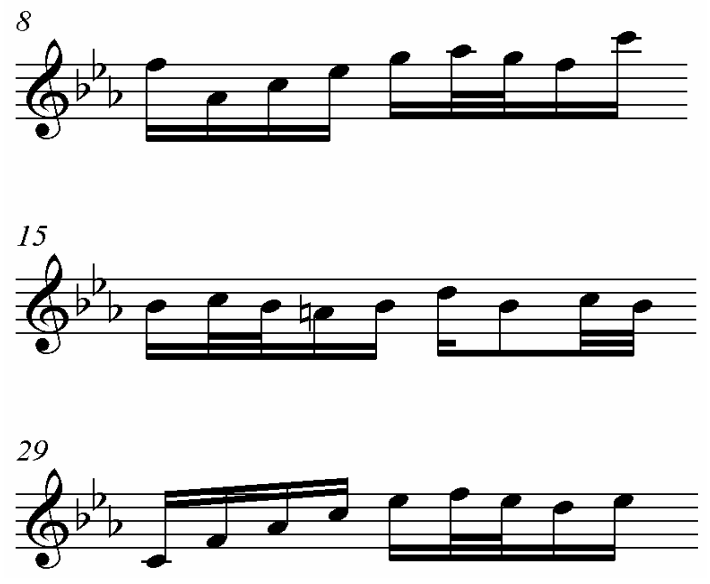

O compasso 15 inicia-se com uma célula rítmica com fusas, inserido em um ritmo mais complexo do que o usual, com notada influência do jazz onde aparece um deslocamento no segundo tempo.

No compasso 22 observamos a mesma célula que ouvimos no compasso 7 .

\section{Exemplo 12}

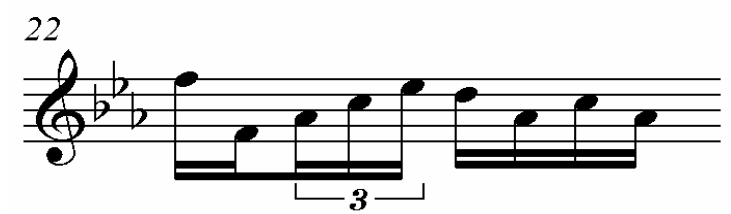

Por último, temos o compasso 29 com o desenho de fusas, já mencionado acima.

Considerações harmônicas:

Neste caso, podemos utilizar a mesma análise do tema, pois ela não se modifica.

Segue abaixo uma tabela com o número de vezes que encontramos fundamentais, terças e sétimas nos tempos fortes. 


\begin{tabular}{|c|c|}
\hline Fundamental & 12 \\
\hline Terça & 8 \\
\hline Sétima & 6 \\
\hline
\end{tabular}

Tabela 1: Velhos Companheiros

\section{Considerações interpretativas:}

K- Ximbinho mantém sua interpretação jazzística tanto no improviso quanto no tema, ou seja, as semicolcheias são sempre "swingadas" - tocadas com intenção de tercinas. Na maior parte das vezes as articulações são executadas partindo-se do tempo fraco para o tempo forte do compasso. Outra importante característica da interpretação de K-Ximbinho são os efeitos expressivos utilizados - as inflexões típicas do jazz. Descreveremos a seguir algumas delas:

Nos primeiros quatro compassos ouvimos os arpejos ascendentes com acento no final de cada grupo de semicolcheias com um crescendo gradual durante a execução das semicolcheias.

No segundo tempo do compasso 3 , a nota mais grave é tocada sem muita força, o que chamamos de ghost notes ${ }^{41}$. No compasso 7 percebemos novamente a intenção de ocultar a nota na tercina descendente.

No compasso 11, já analisados anteriormente, o autor utiliza a escala bebop onde ficam claros os acentos nas notas superiores. Esses acentos reforçam as dissonâncias: b3 - 4 - 4\# e, as notas graves $(\mathrm{Bb})$ quase inaudíveis - que chamamos de ghost notes.

Podemos ouvir nos compassos 17 e 18 que as aproximações cromáticas inferiores e as diatônicas superiores são claramente articuladas com acentos na parte fraca do tempo enfatizando as aproximações.

\footnotetext{
${ }^{41}$ Ghost Notes: É um recurso de articulação em que as notas não possuem uma definição fiel da altura, também conhecida por notas fantasmas ou notas mortas.
} 


\subsubsection{Sempre -Tema}

Esse choro é composto por uma seção A de dezesseis compassos. Nesta seção observamos uma frase que denominamos $A$ nos primeiros oito compassos, nos oito compassos seguintes essa frase se repete, mas não integralmente e a denominaremos A'.

De maneira similar encontramos nos próximos dezesseis compassos uma frase que denominamos de frase $B$, que possui oito compassos e que se repete com modificações, a qual chamaremos de B'. Tanto a seção A quanto a B se repetem; o choro não possui terceira parte, o que como já mencionamos anteriormente era uma característica do autor. Depois de exposto o tema com as respectivas repetições (AABB) K-Ximbinho prossegue com o improviso na parte $A$ e uma reexposição desse mesmo A para finalizar.

\section{Considerações Melódicas:}

A primeira parte do tema é formada por diversos arpejos, ou seja, é construída com características verticais. Nesse início não encontramos motivos melódicos marcantes. A maioria desses arpejos é descendente, com exceção do compasso inicial e da sua repetição na segunda semifrase. No final da segunda semifrase o autor mantém o caráter descendente das melodias, agora caminhando em terças.

\section{Exemplo 13: Sempre-tema, compasso 1 a 8}
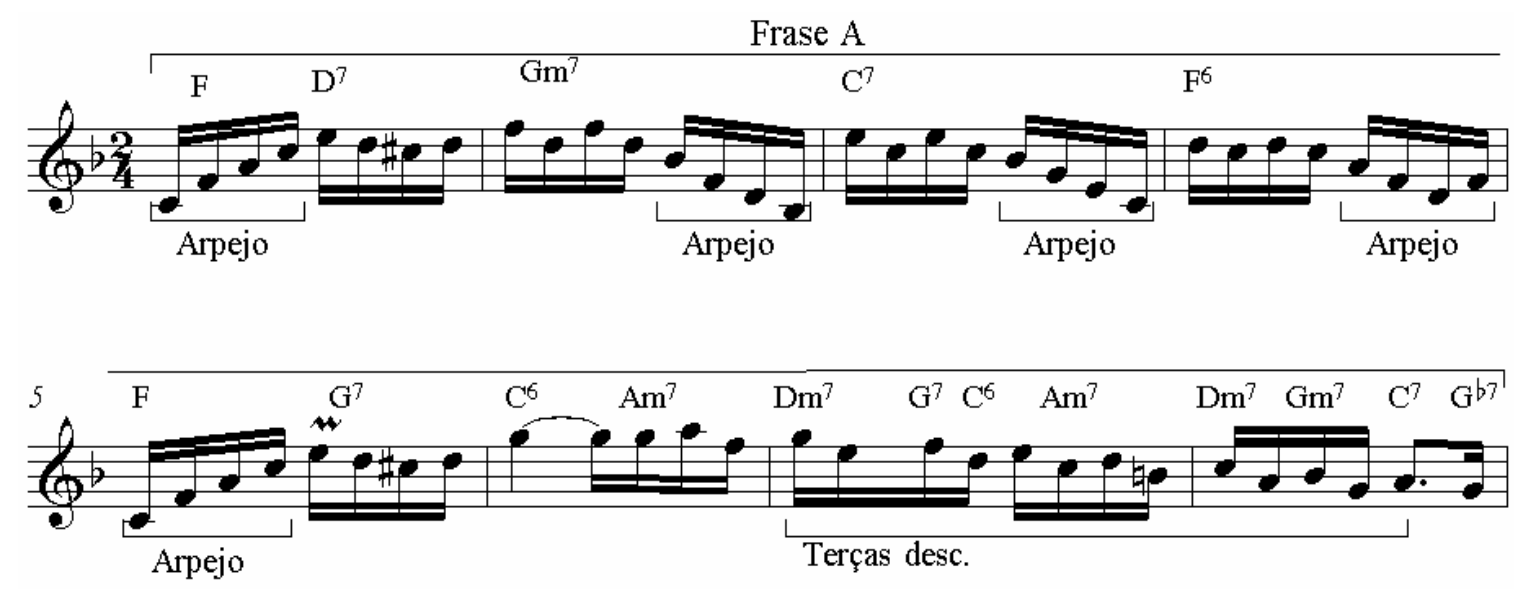
A frase $A^{\prime}$ inicia-se de maneira semelhante, diferenciando-se apenas no compasso 12 para se adequar à harmonia do acorde diminuto. A segunda semifrase continua com o mesmo desenho descendente de arpejo diminuto, seguido com arpejos para uma volta ao $\mathrm{A}$.

\section{Exemplo 14: Sempre-tema, compasso 9 a 16}

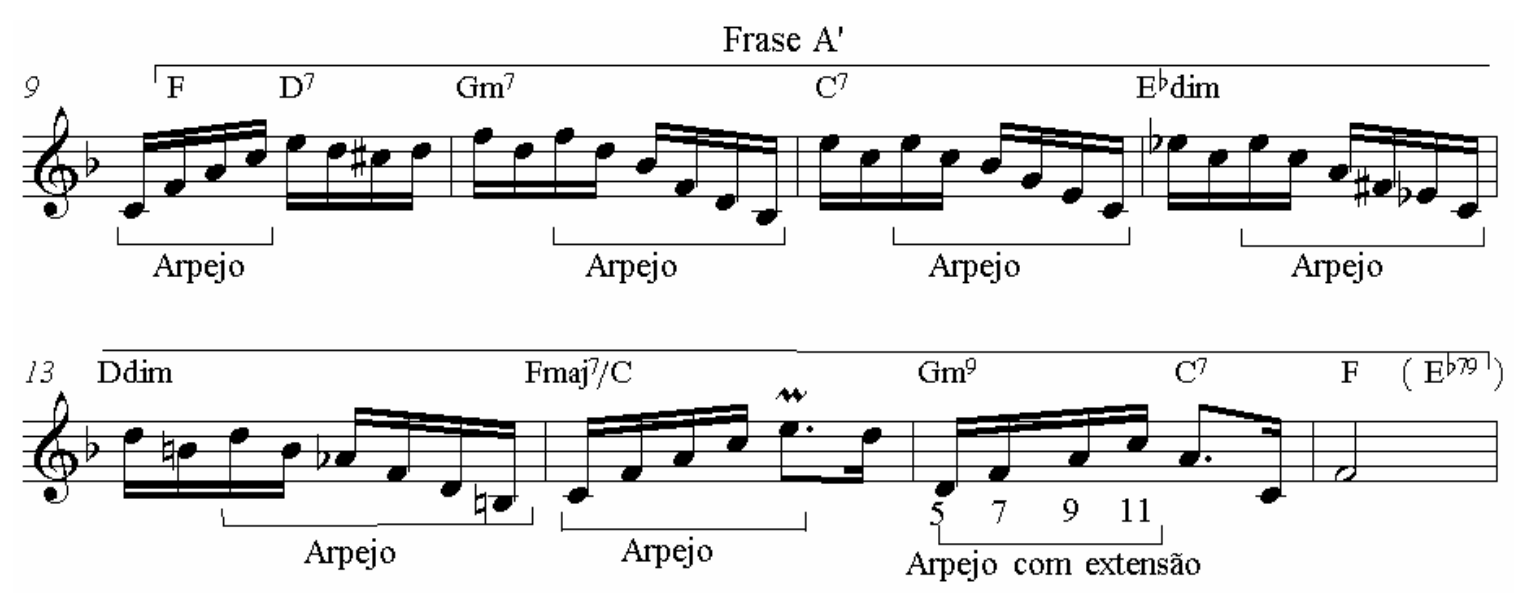

A seguir inicia-se a seção $B$. $O$ autor apresenta a primeira frase que denominamos $B$, de oito compassos (17 a 24), e uma repetição dessa mesma frase que chamamos de frase $B$ '.

Podemos dividir a frase $B$ em duas semifrases de quatro compassos. No compasso 17 aparece o que denominamos motivo 1, formado por aproximações inferiores e superiores - típica do jazz - e se repete no compasso seguinte. Encontramos nos compassos 19 e 20 o que denominamos motivo 2, baseado em arpejos. Nos compassos 21 e 22 chamaremos de motivo 3, que se repete no 23 e 24 apenas com o final diferente, com notas do acorde de Dm. 


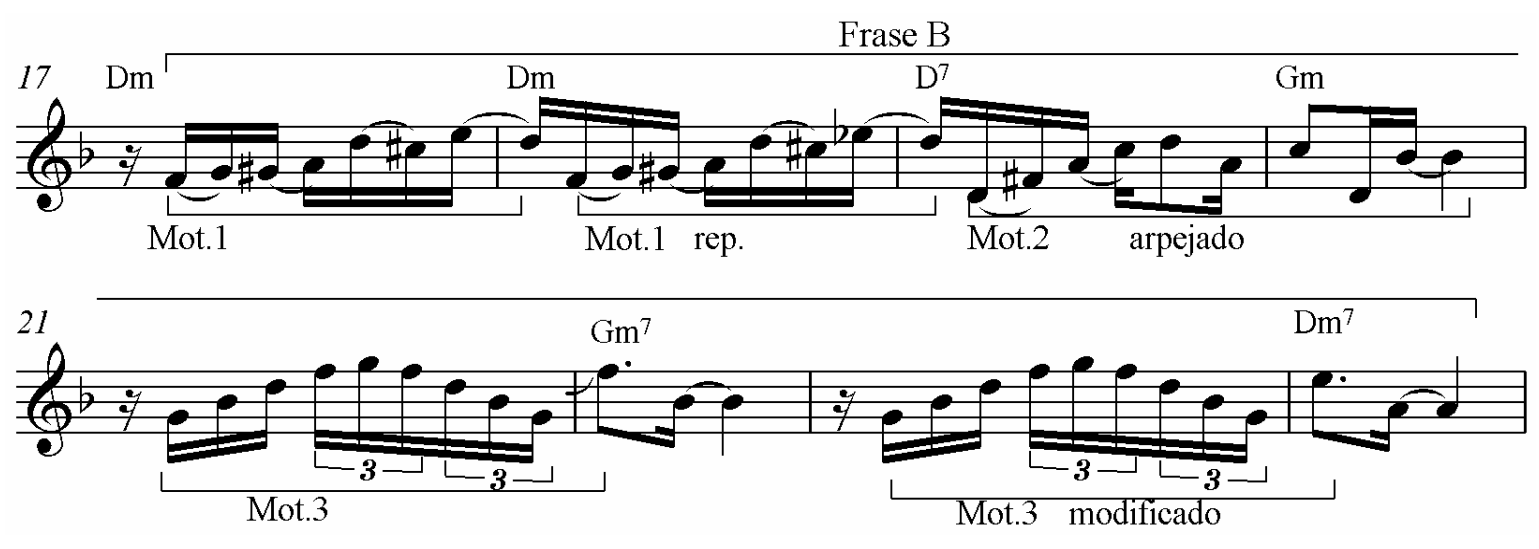

Os quatro primeiros compassos da frase B' são semelhantes ao início da frase B. O motivo 1 aparece no início e em seguida, no compasso 26 , ouvimos 0 motivo 2 ampliado. Isso porque o arpejo de D7 se projeta para o compasso seguinte acrescentando-se a nona do acorde (D7b9); o final do motivo em Gm é praticamente o mesmo, sempre com notas do acorde.

Exemplo 16: Sempre-tema, compasso 25 a 28

Frase $B^{\prime}$

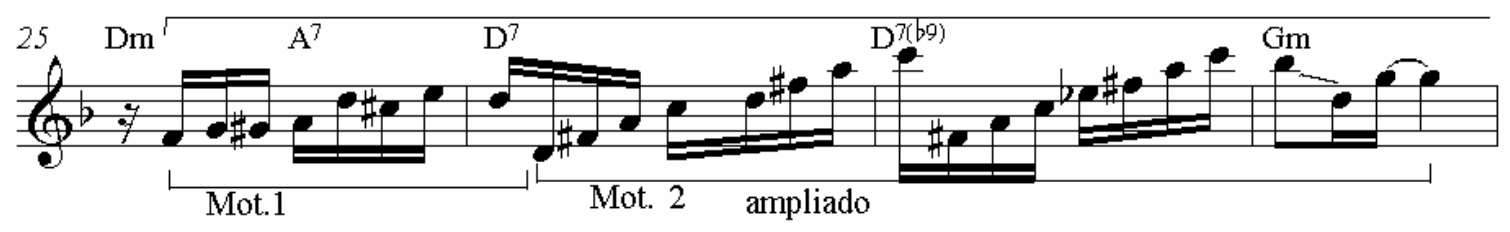

A segunda semifrase possui uma característica conclusiva, por isso a chamamos de coda. As frases são sempre descendentes e nos últimos dois compassos encontramos fundamentais nos tempos fortes, caracterizando uma abordagem vertical. 


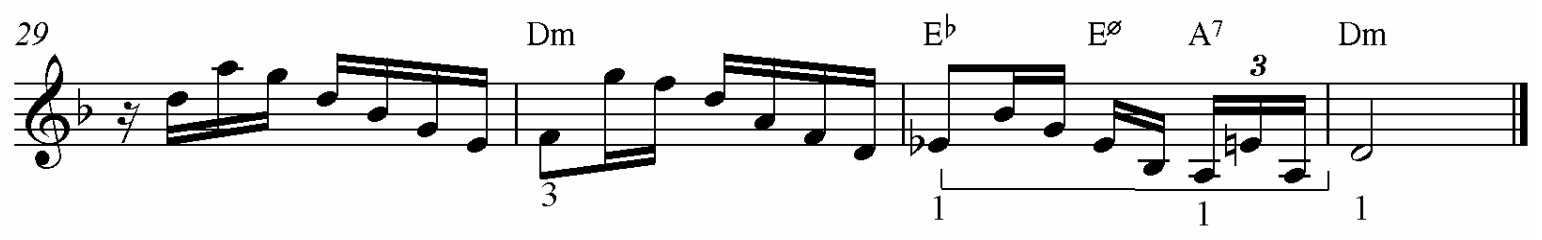

Considerações harmônicas:

A tonalidade da seção A é Fá Maior, passando na seção B ao tom de Re menor.

As considerações relativas à harmonia não são muitas, pois o tema inteiro possui cadências simples e sem alterações relevantes. No compasso 8 encontramos uma rápida seqüência de acordes, o último deles é um acorde de Gb7 que é a dominante substituta do $\mathrm{F}$ do compasso 9 .

\section{Exemplo 18}

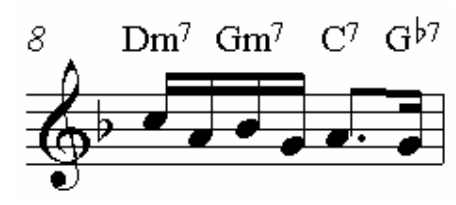

Na frase A' dos compassos 12 e 13, encontramos uma seqüência de acordes diminutos, o que retarda a resolução em $F$, isto é bem demonstrado pelas seqüências melódicas de arpejos descendentes.

\section{Exemplo 19}

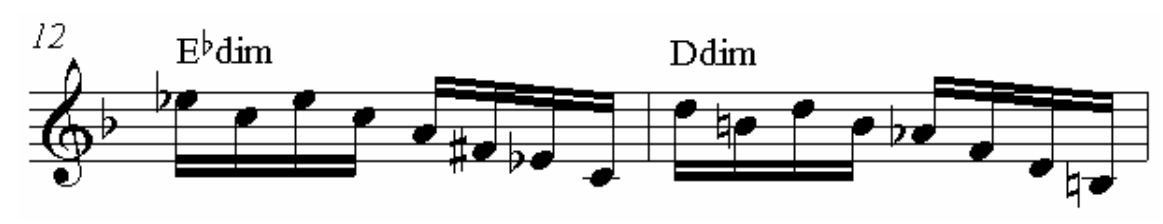

No penúltimo compasso da seção $B$, em Re menor, o autor utiliza um acorde de Eb - também chamada de napolitana com função de sub-dominante - realizando uma espécie de suspensão para resolver na cadência típica II-V-I no tom menor. 


\section{Exemplo 20}

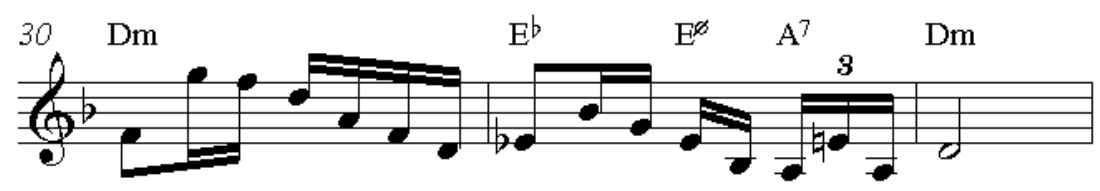

Considerações rítmicas:

Principalmente na primeira parte do tema, que é baseada em arpejos, o ritmo é sempre feito com semicolcheias, somente nos compassos 21 a 24 na parte B é que encontramos uma célula rítmica diferente formada por tercinas de semicolcheias.

\section{Exemplo 21}

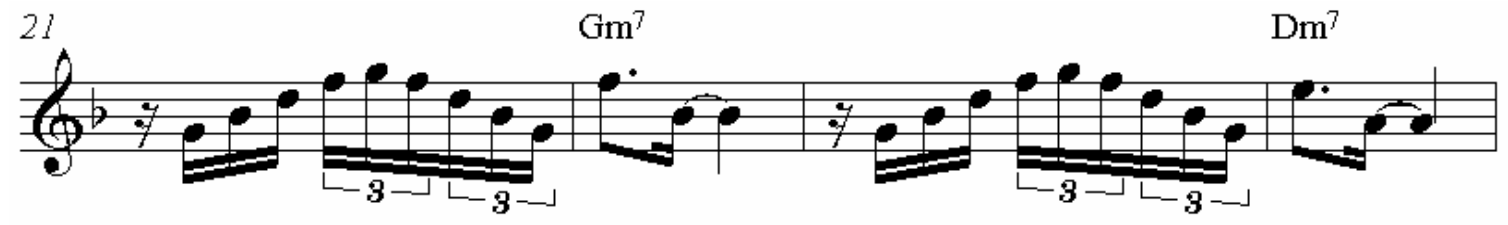

Ainda nessa seção, no penúltimo compasso, uma tercina indica uma espécie de atraso rítmico para a resolução, combinado à parte harmônica que falamos anteriormente.

\section{Exemplo 22}

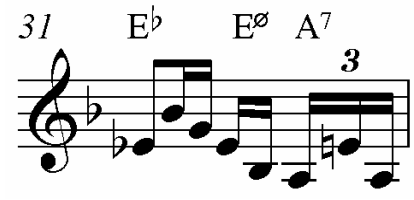

Considerações interpretativas:

Como no choro que analisamos anteriormente podemos encontrar na interpretação do autor um leve swing nas semicolcheias durante todo o improviso. 
A inflexão dos arpejos descendentes no início do tema, acentuando-se as notas agudas e deixando as notas mais graves com um timbre "apagado" revela um sotaque típico do bebop, onde é comum encontrarmos frases descendentes com um ligeiro decrescendo. $\mathrm{Na}$ frase $\mathrm{B}$ dos compassos 17 e 18, ouvimos as notas articuladas e acentuadas no tempo fraco, outra característica do jazz.

\section{Exemplo 23}

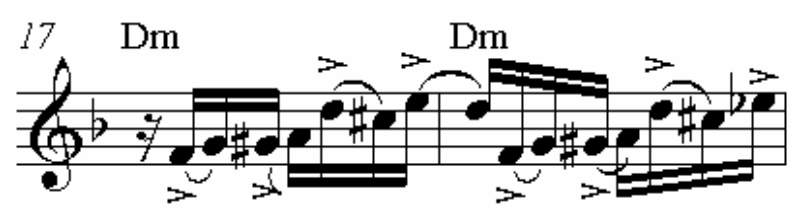

Bend e glissandos ajudam a caracterizar o estilo de K-Ximbinho, aproximando as duas linguagens, a do choro e a do jazz.

\subsubsection{Sempre - Improviso}

Este improviso está baseado somente na seção A do tema, ou seja, nos primeiros dezesseis compassos da música.

Considerações melódicas:

Podemos dividir o improviso em apenas duas frases chamadas de $\mathrm{A}$ e $\mathrm{B}$, de oito compassos cada uma. Na primeira frase observamos uma mistura de escalas e arpejos. No arpejo do segundo compasso notamos algumas extensões do acorde - a $9^{a}$ e a $11^{\text {a }}$. No compasso 5 encontramos um cromatismo que nos leva ao Do, fundamental do acorde seguinte. No compasso 6 o autor descreve uma linha descendente através de um motivo marcante, que se repete nos compassos seguintes até o final da frase. É interessante notar que, a condução melódica dessa escala descendente é mais importante que a harmônica, pois nos tempos fortes nem sempre encontramos graus que definam os acordes: temos $9^{\mathrm{a}}, 4^{\mathrm{a}}, 3^{\mathrm{a}}$ e fundamental. 
Esta é uma característica importante da abordagem horizontal. A repetição dos motivos também faz referência à horizontalidade nestes oito primeiros compassos.

Exemplo 24: Sempre-improviso, compassos 1 a 8
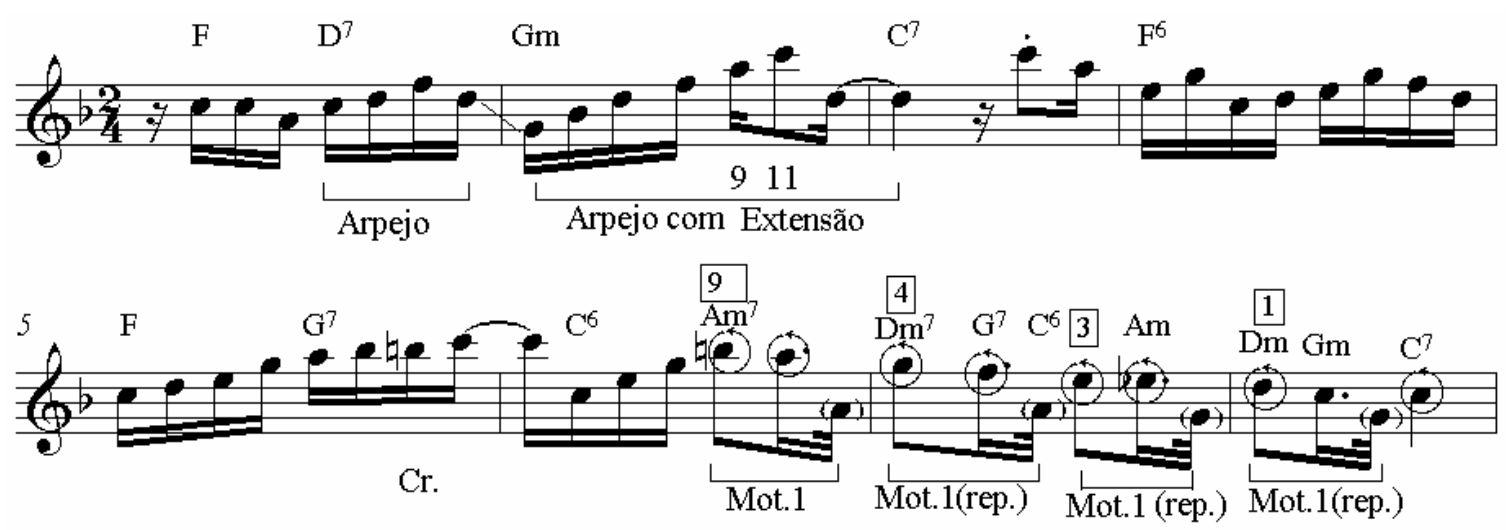

$\mathrm{Na}$ frase $\mathrm{B}$ que vai do compasso 9 ao 16 encontramos uma lembrança do tema (compassos 10 e 11) formado por quartas e terças descendentes.

No final da frase encontramos arpejos sobrepostos - sobre o acorde de Ddim KXimbinho apresenta um arpejo de Gm7 apoiando-se na 9a , e no de $\mathrm{F}$ um arpejo de Dm - e fragmentos de escalas.

Exemplo 25: Sempre-improviso, compassos 9 a 16

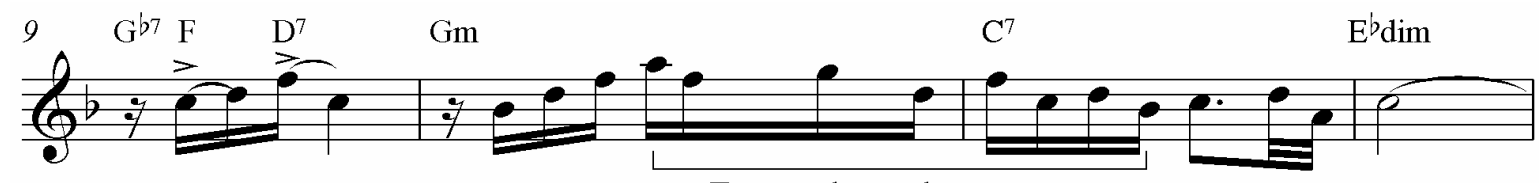

Terças descendentes lembrança do tema

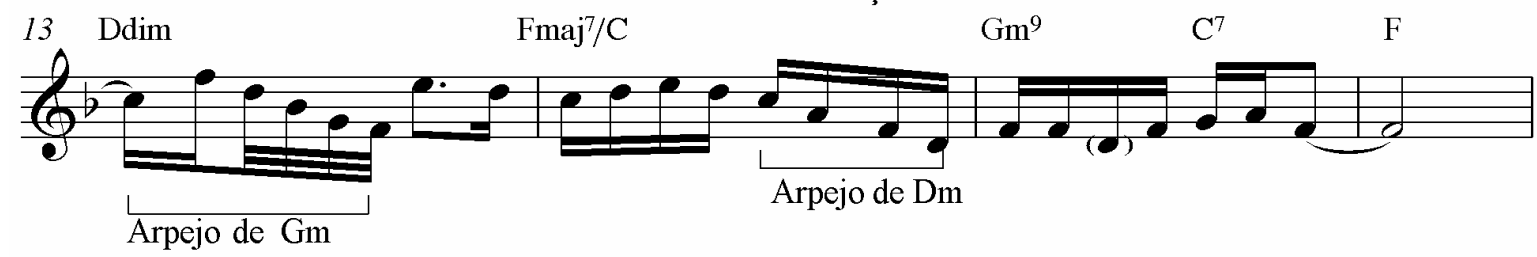

Neste trecho temos uma lembrança do tema, o que consideramos uma característica horizontal, pois sobre a cadência Gm - C7 - Ebdim o autor privilegia o 
motivo horizontal. Mesmo nos compassos seguintes os arpejos utilizados não determinam claramente o caminho harmônico.

Considerações rítmicas:

Quanto à rítmica desse improviso, consideramos como ponto mais importante a frase dos compassos 6,7 e 8 onde encontramos uma repetição de motivos em seqüência descendente. Essa célula rítmica, associada ao modo de interpretação nos remete ao som do prato da bateria no ritmo do swing.

\section{Exemplo 26}

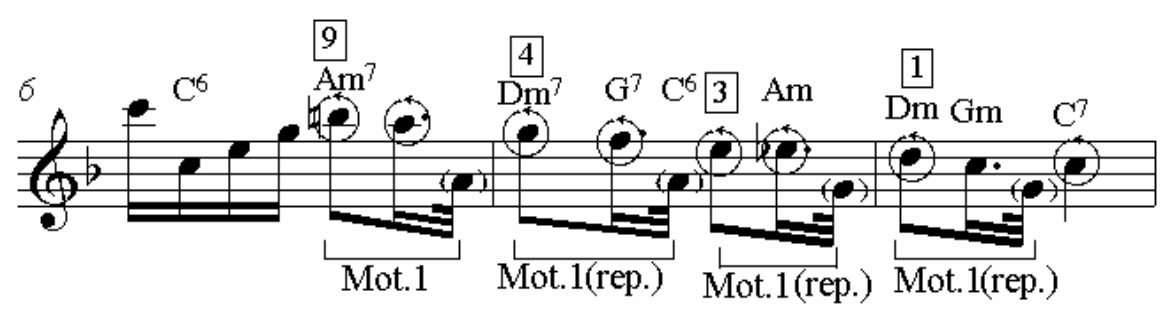

Outra célula que se diferencia das típicas do choro são encontradas no compasso 13.

\section{Exemplo 27}

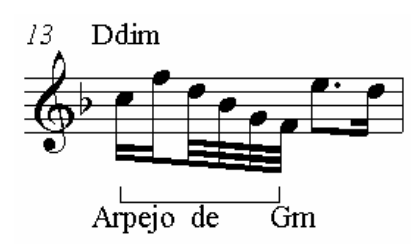

Considerações harmônicas:

Idem ao tema. 
Como fizemos anteriormente segue abaixo uma tabela com o número de fundamentais, terças e sétimas que encontramos em tempo forte durante 0 improviso.

\begin{tabular}{|c|c|}
\hline Fundamental & 7 \\
\hline Terça & 1 \\
\hline Sétima & 4 \\
\hline
\end{tabular}

Tabela 4

Considerações interpretativas:

Do primeiro para o segundo compasso notamos uma espécie de glissando, que liga as notas; essa é uma maneira de tocar em que as notas são executadas com maleabilidade, mais à vontade. A última nota do motivo, nos compassos 6,7 e 8 quase não aparece, é o que chamamos ghost notes e que já foi explicado anteriormente. No penúltimo compasso notamos também esse recurso de expressão típico do jazz, somado a uma grande liberdade de articulação.

\section{3 - Lá vem a Baiana (Análise complementar)}

Como são poucas as gravações nas quais K-Ximbinho improvisa, incluímos a título de complementação o improviso sobre o tema de Dorival Caymmi Lá vem a Baiana, que apesar de não se tratar de um choro e sim de um samba, exemplifica claramente seu estilo de improvisação.

Este tema foi lançado por K-Ximbinho em 1958, no disco Em ritmo de dança vol. $3^{42}$. Neste caso, iremos nos limitar às análises melódicas que são as mais importantes para nossa investigação.

\footnotetext{
42 Em ritmo de dança Polydor LPNG 4015, com o quinteto de k-ximbinho.Walter Gonçalves no piano; Vidal no contrabaixo; Hugo Tagnin na bateria e Nestor Campos na guitarra.
} 


\section{Considerações melódicas:}

Denominamos frase A os primeiros oito compassos do improviso. Essa frase inicia-se com a própria melodia e em seguida desenvolve-se através de escalas e motivos com características importantes, que examinaremos a seguir.

No compasso 2, logo após a citação da melodia, o autor repete o que chamamos anteriormente de motivo 1, sendo que a primeira repetição é integral e no compasso 3, aparece ligeiramente modificado seguido de uma escala descendente.

No compasso 7, assinalamos um segundo motivo que também se repete modificado no compasso seguinte. Observamos no final desse motivo uma quinta ascendente, e na sua repetição a quinta passa a ser descendente, expressando um caráter conclusivo.

\section{Exemplo 28: Lá vem a baiana, compassos 1 a 8}

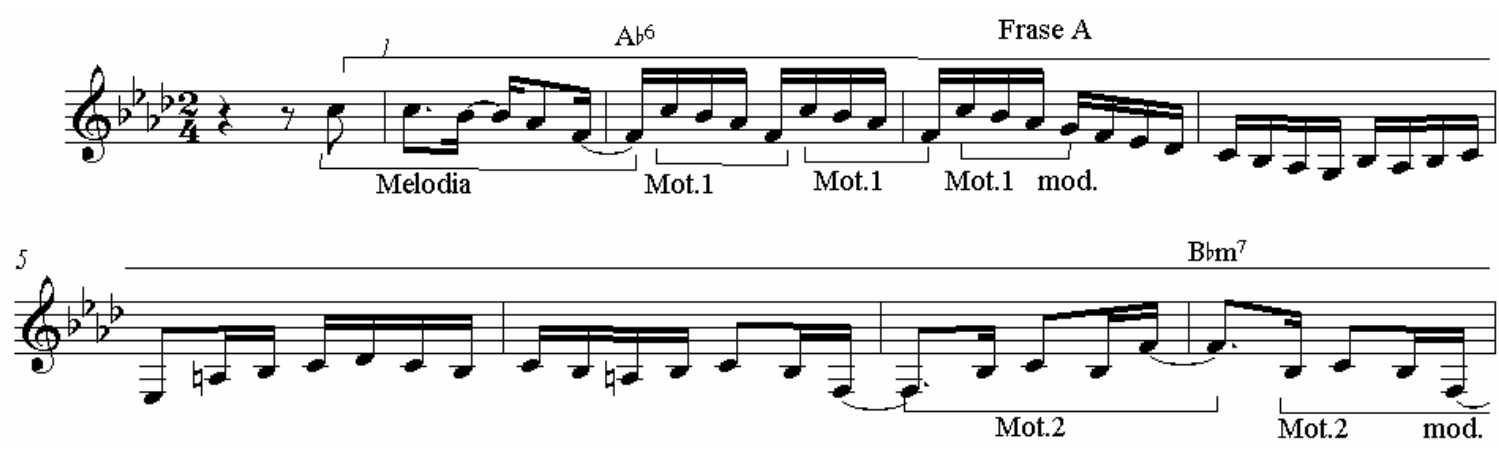

As características de abordagem horizontal neste início de improviso podem ser demonstradas pela citação da melodia no compasso 1 e também pela repetição de motivos que K-Ximbinho utiliza.

A frase B inicia-se no compasso 9 ( com anacruse) com outra citação da melodia, dessa vez modificada. Uma escala descendente faz uma ligação com os dois compassos seguintes - compassos 11 e 12 - onde aparece um motivo denominado 3 , a sua repetição é levemente ampliada. No final dessa frase observamos apenas escalas. 
Exemplo 29: Lá vem a baiana, compassos 9 a 16

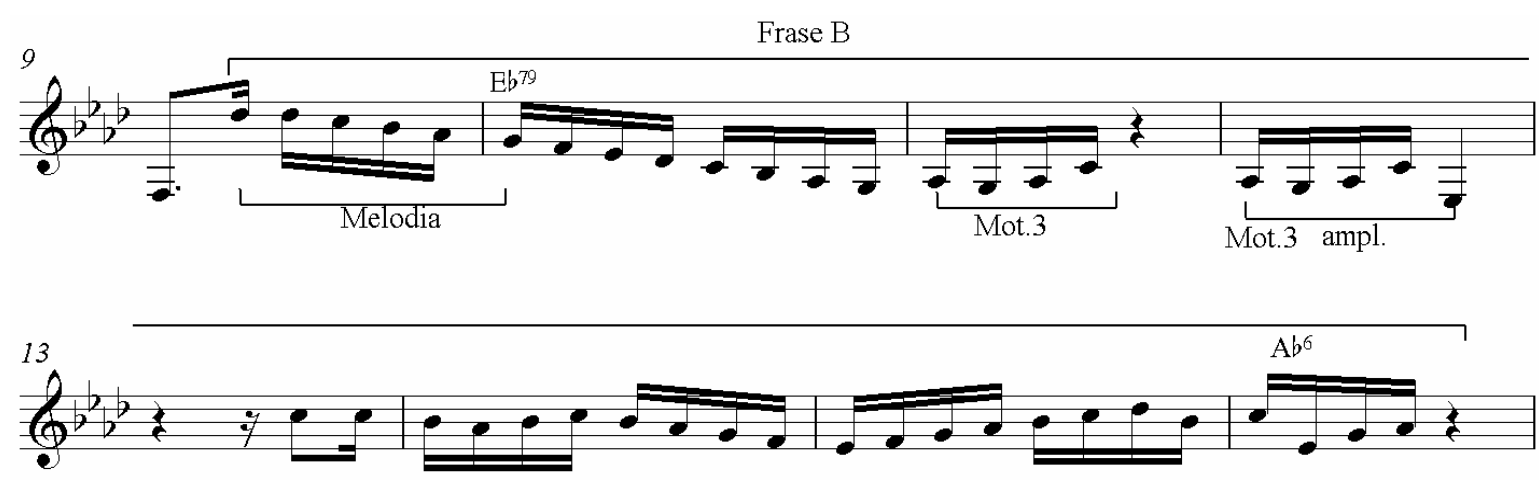

Novamente observamos nesse trecho construções melódicas baseadas principalmente em escalas, motivos que se repetem e lembrança da melodia ressaltando a horizontalidade. Além das escalas iniciais, encontramos na frase $\mathrm{C}$ a repetição do motivo 2, originalmente antecipado e que aqui aparece na cabeça do tempo.

Exemplo 30: Lá vem a baiana, compassos 17 a 25

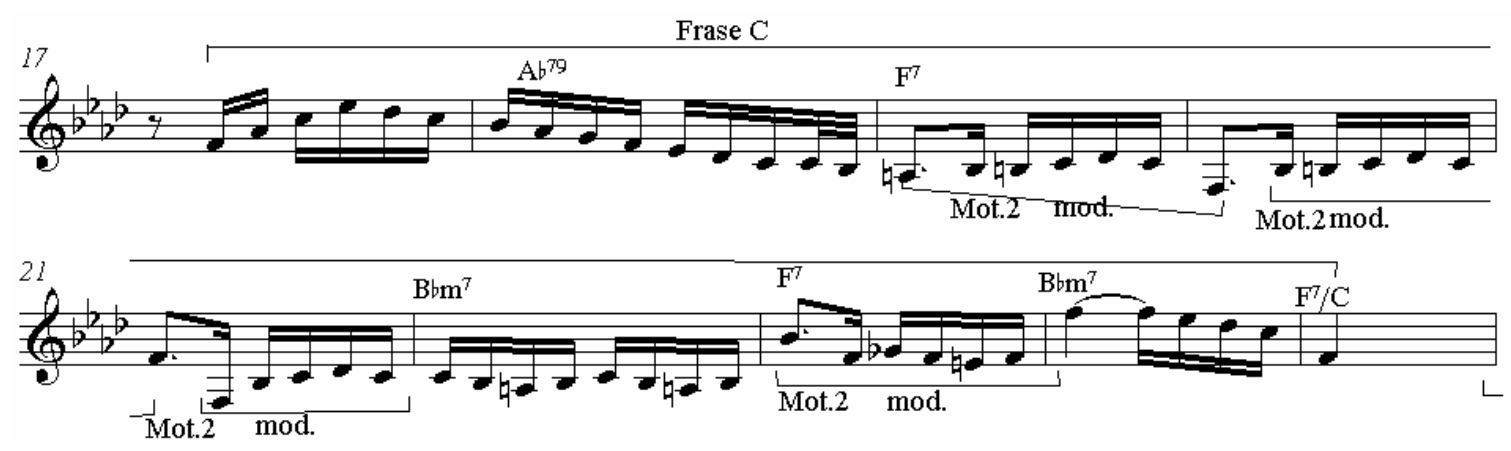

As características dessa frase são similares às anteriores, com repetições de motivos e fragmentos de escalas.

A frase $D$ inicia-se também pela melodia seguida por escalas descendentes; um novo motivo pode ser observado no compasso 31. Esse motivo que denominamos de motivo 4 é formado por quatro semicolcheias e se repete por mais três vezes até o compasso 32. Essa frase finaliza-se com mais uma repetição do motivo 2 modificado. 
Exemplo 31: Lá vem a baiana, compassos 26 a 34

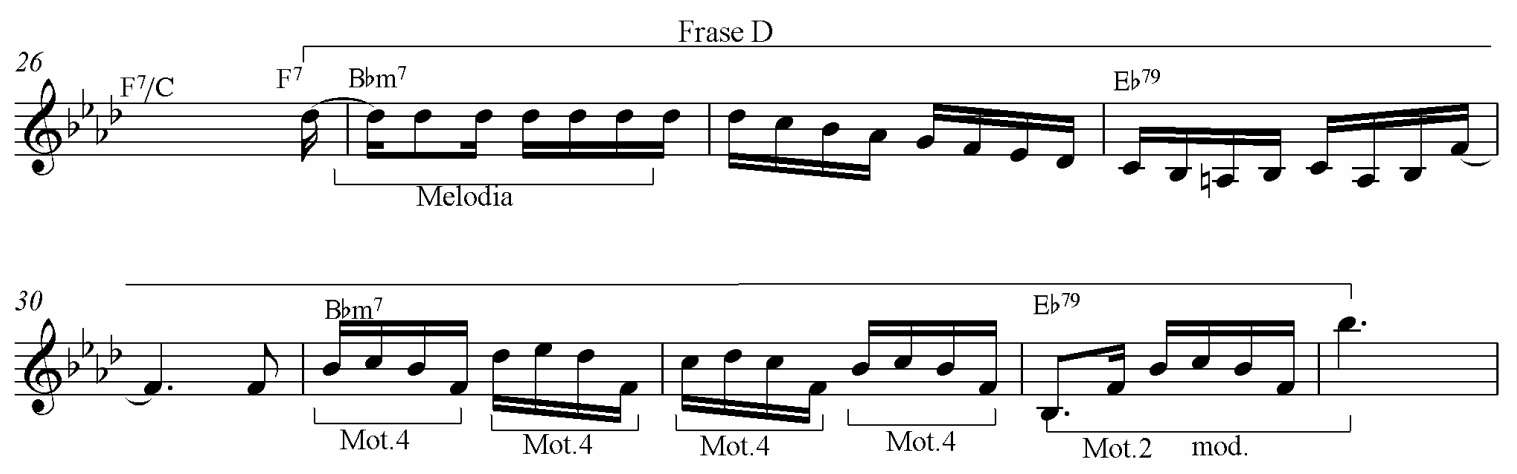

A frase $E$ é formada principalmente por escalas; encontramos no compasso 39 e 40 um trecho da melodia que liga-se à última frase, chamada de frase-coda, composta pelo final da frase $\mathrm{E}$ expressando uma idéia de Fade Out ${ }^{43}$.

Exemplo 32: Lá vem a baiana, compassos 35 a 46

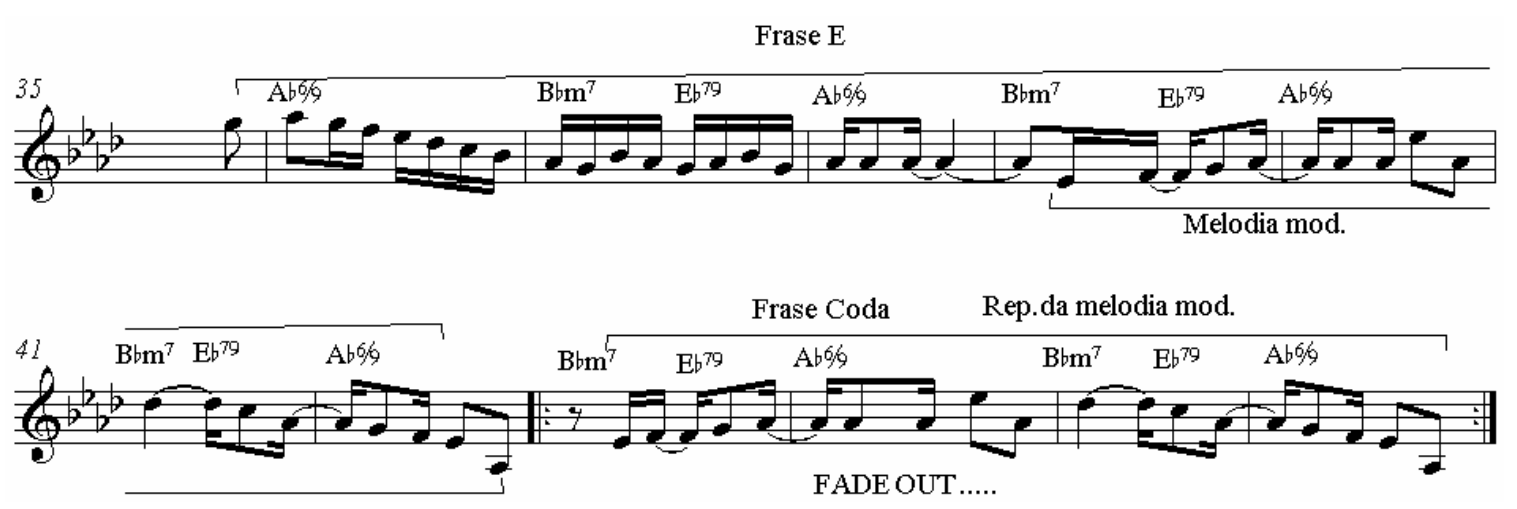

\section{3 - Considerações finais}

Analisamos três improvisos de K-Ximbinho, os dois primeiros sobre choros de sua autoria e o terceiro sobre um samba de Dorival Caymmi.

Como características principais podemos observar que o autor tem uma grande preocupação em apresentar frases longas com vários motivos rítmicomelódicos que são trabalhados criativamente, alterando-os de diversas maneiras. Nos três exemplos a valorização das linhas horizontais está presente de maneira

\footnotetext{
${ }^{43}$ Fade Out: diminuição gradual do som que geralmente acontece no final da música.
} 
marcante por meio dos desenvolvimentos motívicos e referência ao tema em diversas ocasiões, com preferência às escalas ao invés de arpejos.

Nos dois choros o autor utiliza uma interpretação com muitas influências da música americana através de recursos de articulação, rítmicas diferenciadas e uso de escalas características. Podemos concluir que K-Ximbinho procurava mesclar os dois idiomas, choro e jazz.

No terceiro exemplo, o samba Lá vem a baiana, o estilo do fraseado revela-se bem brasileiro, principalmente no modo de interpretação, no "sotaque" e as colcheias são tocadas sem swing quer dizer não como "tercinas", nesse caso percebemos pouca mistura de estilos.

Examinando os improvisos de K-Ximbinho percebe-se sua preferência pela abordagem horizontal, pois na maioria das vezes há preocupação com o aspecto melódico que se sobrepõe ao harmônico. Observamos nesses exemplos que para K-Ximbinho a seqüência de acordes não é determinante em sua forma de improvisar e enfatiza principalmente o aspecto melódico horizontal, não prioriza a plena definição do caminho harmônico, apesar de sempre se adequar a ele. Gostaríamos de ressaltar em algumas ocasiões a presença da abordagem vertical, como marcamos nas análises, porém em poucas ocasiões se comparada às características horizontais. 


\section{CONCLUSÃO}

Fizemos nesta dissertação uma análise comparativa de dois estilos de improvisação no choro brasileiro, propondo uma reflexão sobre o importante papel que o improviso desempenhou nesse gênero musical. $O$ exame dessa prática possibilitou entender a diversidade de opções que se abrem nesse "fazer" musical, tornando familiares alguns elementos que fazem parte dessas criações.

Por meio das análises que realizamos dos improvisos de Pixinguinha e KXimbinho, procuramos examinar os caminhos traçados por esses dois compositores na criação de seus improvisos e, assim, caracterizar duas estruturas básicas de construção. Essa escolha se deu por entendermos que nas obras desses dois compositores encontramos marcas exemplares dessas estruturas. Deste modo, pudemos definir dois tipos de abordagens presentes nos improvisos estudados: vertical e horizontal.

Notamos nos improvisos das peças escolhidas de Pixinguinha uma importante influência das raízes do choro, das bandas militares, dos grupos regionais; nos de K-Ximbinho além da presença da linguagem do choro, percebemos uma forte influência do jazz norte-americano. A existência das diferenças entre eles pode ser explicada por terem vivido em cenários e épocas diferentes, com escutas musicais variadas.

Gostaríamos de ressaltar que usamos como campo para nossa pesquisa somente as questões musicais, para estabelecer uma espécie de "confronto" entre eles. Outra abordagem - fora dos nossos objetivos - seria investigar as causas sociais, culturais ou históricas que poderiam ter auxiliado a compreender em parte as diferenças entre eles.

Apesar de examinarmos sucintamente as partes harmônicas, rítmicas e interpretativas, na comparação que nos propusemos fazer, levamos em conta principalmente as partes melódicas, que são determinantes na definição da horizontalidade e da verticalidade dentro da construção do improviso. 
Segundo os conceitos propostos por George Russell e estudados por Berton, que apresentamos nesse trabalho, a característica fundamental de uma construção vertical está baseada em arpejos e tem como principal preocupação a definição das seqüências harmônicas da música; por outro lado, na horizontalidade a construção da melodia não é realizada definindo claramente cada acorde e sim por escalas relacionadas ao centro tonal, ou seja, a mais de um acorde. Sabemos que as notas mais importantes na definição dos acordes e de suas funções são as fundamentais, as terças e as sétimas.

Comparando Pixinguinha e K-Ximbinho conforme os dados das tabelas referentes à quantidade de vezes que utilizam fundamentais, terças e sétimas em tempo forte, apresentadas nos capítulos anteriores, temos:

\begin{tabular}{|c|c|c|c|c|}
\hline Nome & $\begin{array}{c}\text { № de } \\
\text { compassos/tempo }\end{array}$ & Fundamental & Terça & Sétima \\
\hline $\begin{array}{c}1 \text { a 0 } \\
\text { (Pixinguinha) }\end{array}$ & $128 / 256$ & $80 / 31,25 \%$ & $35 / 13,67 \%$ & $18 / 7,03 \%$ \\
\hline $\begin{array}{c}\text { Pagão } \\
\text { (Pixinguinha) }\end{array}$ & $96 / 192$ & $77 / 40,10 \%$ & $48 / 25,00 \%$ & $12 / 6,25 \%$ \\
\hline $\begin{array}{c}\text { Velhos } \\
\text { Companheiros } \\
\text { (K-Ximbinho) }\end{array}$ & $32 / 64$ & $12 / 18,75 \%$ & $8 / 12,50 \%$ & $6 / 9,37 \%$ \\
\hline $\begin{array}{c}\text { Sempre } \\
\text { (K-Ximbinho) }\end{array}$ & $16 / 32$ & $7 / 21,87 \%$ & $1 / 3,12 \%$ & $4 / 12,50 \%$ \\
\hline
\end{tabular}

Tabela de comparação

Com isso, observamos em Pixinguinha a grande utilização desse procedimento vertical se comparado à K-Ximbinho, que normalmente não prioriza a definição de cada acorde. Este tem uma preocupação com um fraseado mais amplo, executa trabalho sobre motivos melódicos e rítmicos alterados de diversos modos, além de utilizar o tema diversas vezes como material de composição. Por isso, notamos uma preferência pela abordagem horizontal nos improvisos de K-Ximbinho. 
Quanto à questão rítmica, notamos em K-Ximbinho desenhos rítmicos diferenciados, também empregados como motivos. Em Pixinguinha o que observamos é uma rítmica na maioria das vezes constante e regular.

Quando afirmamos que os improvisos de K-Ximbinho possuem um claro pensamento melódico (horizontal), distinguindo-se dos de Pixinguinha, que se baseiam fundamentalmente no desenho harmônico (vertical), não estamos afirmando que o primeiro só fazia improvisos baseados na harmonia e não se preocupava com o desenho melódico, nem que K-Ximbinho não utilizava acordes ou delineava a harmonia. O que notamos é uma preponderância de um desses "caminhos" no estilo de cada músico. A barreira que separa as duas abordagens é tênue, e por vezes, uma não exclui a outra; podemos notar, em muitos momentos, que elas coexistem.

Este estudo poderá ser usado como estratégia pedagógica no sentido de estimular no estudante a capacidade de trabalhar com as estruturas musicais de modo criativo.

Lidar com diferentes estilos de improviso indica ao aluno que por trás de um estilo há uma técnica que está sendo aplicada. O estudo dos procedimentos de improviso desempenha uma importante função no aprimoramento dos estudantes desta área.

Apesar da tendência que há em se relacionar o instrumento saxofone e a improvisação ao contexto do jazz, a música brasileira sempre foi o principal propósito dos nossos estudos Como as pesquisas sobre música instrumental brasileira relacionadas a esse tema ainda estão no início, acreditamos que esta dissertação auxiliará no esclarecimento de alguns tópicos referentes à criação de um improviso e à caracterização de estilos.

Procuramos aqui contribuir para que o choro, gênero vivo dentro da nossa música popular, possa continuar seu desenvolvimento e encontrar novos caminhos principalmente no que diz respeito à improvisação. 


\section{BIBLIOGRAFIA}

\section{Referências Bibliográficas:}

Livros:

ALBIN, Ricardo Cravo. O livro de ouro da MPB: A história de nossa música popular de sua origem até hoje. Rio de Janeiro: Ediouro, 2003.

BAILEY, Derek, Improvisation, its nature and practice in music, England Ashbourne: Da Capo Press, 1993.

BERENDT, Joachim E. O Jazz: do Rag ao Rock, Rio de Janeiro: Editora Perspectiva, 1987.

CABRAL, Sérgio. Pixinguinha: Vida e obra. Rio de Janeiro: Lumiar Editora,1997.

CALADO, Carlos. O jazz como espetáculo. São Paulo: Perspectiva (Série Debates), Secretaria do Estado da Cultura, 1990

CAZES, Henrique. Choro: do quintal ao municipal. 2a . Ed. São Paulo: Editora 34,1999 .

COOK, Nicholas. A Guide to Musical Analysis. London: J. M. Dend \& Sons, 1987.

DAHLHAUS. Carl. Fundamentos de la historia de la música. Barcelona: Editorial Gedisa, 1997.

FONTERRADA, Maria Trench de Oliveira. De tramas e fios: um ensaio sobre música e educação. São Paulo: Editora UNESP, 2005.

FRANCESCHI, Humberto Moraes. A Casa Edison e seu tempo. Rio de Janeiro:Petrobrás/ Sarapuí/Biscoito Fino, 2002.

GROVE, Dicionário de música. Rio de Janeiro: Jorge Zahar ed.,1994. 
LIMA BARRETO, A.H. de. Numa e a ninfa. São Paulo: Editora Brasiliense,1956.

NEVES, José Maria. Villa-Lobos, o choro e os Choros. São Paulo: Ricordi Brasileira,1977.

NAPOLITANO, Marcos. História e Música - história cultural da música popular. Belo Horizonte: Autêntica, 2002.

PINTO, Alexandre Gonçalves. O choro. Rio de Janeiro: Edição FUNARTE, 1978.

RUSSELL, George - Lidian Cromatic Concept of Tonal Organization - Concept Publish Company, 40 Shepard Street; Cambridge, MA 02138, 2001.

SCHOENBERG, Arnold. Fundamentos da composição musical. São Paulo: Ed. da Universidade de São Paulo, 1991.

SCHULLER, Gunther. Early Jazz: It's roots and musical development. New York: Oxford University Press, 1986.

SILVA, Marília Barboza da \& OLIVEIRA FILHO, Arthur L. de. Pixinguinha - filho de Ogum Bexiguento. Rio de Janeiro: Gryphus, 1998.

TINHORÃO, José Ramos. Pequena História da Música Popular. Petrópolis:

Vozes,1974. . História social da música popular brasileira. São Paulo: Ed. 34, 1998. . Música popular: um tema em debate. São Paulo: Ed. 34, 1997. 1976. . Música popular: Sons que vêm da rua. Rio de Janeiro: Ed. Tinhorão,

VASCONCELOS, Ary. Carinhoso Etc. (história e inventário do choro). Rio de Janeiro: Gráfica Editora do Livro Ltda., 1984. .Panorama da Música Popular Brasileira na "Belle Époque". Rio de Janeiro: Livraria Sant'Anna, 1977.

Artigos, Dissertações e Teses:

ALVES, Andréia Ribeiro (17/ 09/1995). "Repertório incontável guardado "de ouvido". O Estado de São Paulo. Caderno 2, p. 6. 
ARATANHA, Mario de. "A essência musical da alma brasileira". Revista Roda de Choro no. 2. Rio de Janeiro: mar/abr, 1996.

ARAÚJO, Mozart de. "Ernesto Nazareth" - Separata da Revista Brasileira de CulturaAbril/Junho, 1972.

BAIA, Silvano. "A Pesquisa sobre Música Popular em São Paulo". São Paulo: UNESP,2005. (Dissertação)

BASTOS, Marina Beraldo Bastos e PIEDADE, Acácio Tadeu de Camargo. O desenvolvimento histórico da música instrumental, o jazz brasileiro. Anais do Simpósio de pesquisa em música 2005. Curitiba: UFPR/ DeArtes, 2005.

BERTON, Inventividade melódica: Uma outra abordagem das técnicas de análise, composição e improvisação em música popular. Campinas: UNICAMP, 2005. (Dissertação)

BESSA, Virgínia de Almeida. "Um bocadinho de cada coisa": trajetória e obra de Pixinguinha. São Paulo: USP/FFLCH, 2005. (Dissertação)

FABRIS, Bernardo V. Catita de k-ximbinho e a interpretação do saxofonista Zé Bodega: aspectos híbridos entre 0 choro e 0 jazz. Belo Horizonte: UFMG/Música, 2006. (Dissertação)

IKEDA, Alberto T., "Apontamentos Históricos sobre o Jazz no Brasil: Primeiros Momentos". Comunicações e Arte, Vol. 13, 1984.

K-XIMBINHO. Entrevista a Paulo Moura (1980). In: Saudades de um clarinete. (LP de vinil $33 \mathrm{rpm}$, contra-capa).

NETLL, Bruno. O estudo comparativo da mudança musical: Estudos de caso de quatro culturas. In: I encontro nacional da ABET 2002, Recife, Anais.

LOUREIRO DE SÁ, Paulo Henrique. Receita de choro ao molho de bandolim: uma reflexão acerca do choro e sua forma de criação. Rio de Janeiro: Conservatório Brasileiro de Música, 1999.(Dissertação)

Improviso no choro. Revista Pesquisa e Música, Vol.5- n.1: Conservatório Brasileiro de Música, 2000.

MAGALHÃES, Alexandre Caldi. Contracantos de Pixinguinha: contribuições históricas e analíticas para a caracterização do estilo. Rio de Janeiro: Unirio, Música Brasileira, 2000. (Dissertação) 
MORAES, José Geraldo V. "História e música: canção popular e conhecimento histórico". Revista Brasileira de História, 20/39, ANPUH/ Humanitas/ FAPESP, 2000, p.203-222.

OLIVEIRA, Samuel. Choro: um estudo histórico e musicológico. Florianópolis: UDESC, 2000. (Trabalho de Conclusão do Curso de Música)

PETERS, Ana Paula. "O regional, o rádio e os programas de auditório: nas ondas sonoras do Choro" (UFPR) Revista eletrônica de musicologia, Vol. VIII Dezembro de 2004.

PIXINGUINHA. Série Depoimentos. Rio de Janeiro: Museu da Imagem e do som, 1997.

PIEDADE, Acácio Tadeu de Camargo. "Jazz, Música Brasileira e fricção de musicalidades". Revista Opus. 11, 2005, p. 197-207.

Análise musical e música popular brasileira: em busca de tópicas. II Jornada de Pesquisa do Centro de Artes, Florianópolis, 2006. Anais, Florianópolis:UDESC,2006.

Expressão e sentido na música brasileira: retórica e análise musical. Revista Eletrônica de Musicologia. Vol.11, 2007.

SALEK, Eliane Corrêa. A flexibilidade rítmico-melódica na interpretação do choro. Rio de Janeiro: UFRJ, 1999. (Dissertação)

TINÉ, Paulo José de Siqueira. Três compositores da música popular do Brasil: Pixinguinha, Garoto e Tom Jobim. Uma análise comparativa que abrange $o$ período do Choro à Bossa nova. São Paulo: ECA-USP, 2001. (Dissertação)

WEFFORT, Alexandre Branco. Choro: Expressão Musical Brasileira - caminhos de aproximação ao universo do choro, 2002. Disponível em

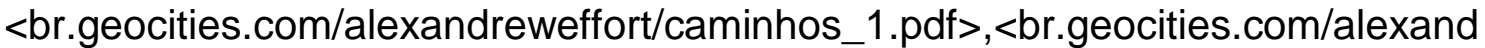
reweffort/caminhos_2.pdf,<br.geocities.com/alexandreweffort/caminhos_3.pdf Acesso em Maio/2008.

\section{Obras de referência:}

ALENCAR, Edigar de. O fabuloso e harmonioso Pixinguinha. Rio de Janeiro: Cátedra-INL, 1979.

ALMADA, Carlos. A estrutura do choro: com aplicações na improvisação e no Arranjo. Rio de Janeiro: Da Fonseca, 2006. 
BERLINER, Paul. Thinking in jazz: the infinite art of improvisation, Chicago: University of Chicago Press, 1994.

CASCUDO, Luis Câmara. Folclore do Brasil, Pesquisas e Notas Rio de Janeiro: Editora Fundo de Cultura, 1967.

EFEGÊ, Jota. Figuras e coisas da música popular brasileira. 2 volumes. Rio de Janeiro: Funarte, 1978.

HOBSBAWM, Eric J. História social do jazz. Rio de Janeiro: Paz e Terra, 1990.

KIEFER, Bruno. História da música brasileira: dos primórdios ao início do século XX. Porto Alegre: Movimento, 1976.

MOURA, Roberto. Tia Ciata e a pequena África no Rio de Janeiro. Rio de Janeiro: FUNARTE,1983.

NACHMANOVITCH, Stephen. Ser criativo. São Paulo: Summus, 1993

RANGEL,Lúcio. Sambistas e Chorões. Aspectos e figuras da música popular brasileira. Rio de Janeiro: Francisco Alves, 1962.

SANDRONI, Carlos. Feitiço decente. As transformações do samba no Rio de Janeiro (1917-1933). Rio de Janeiro: Ed.UFRJ/Zahar, 2001.

SÈVE, Mário. Vocabulário do choro - estudos e composições. Rio de Janeiro: Lumiar Editora, 1999.

SEVERIANO, Jairo e MELLO, Zuza Homem de. A canção no tempo. 85 anos de músicas brasileiras. São Paulo: Ed.34, 2002.

SIQUEIRA, João B. Três vultos históricos da música brasileira: Mesquita, Calado e Anacleto. Rio de Janeiro: Funarte, 1970.

SWANWICK, Keith. Ensinando a música musicalmente. São Paulo: Moderna, 2003. 
VASCONCELLOS, Gilberto. Música popular: de olho na fresta. Rio de Janeiro: Graal, 1977.

WISNIK, José Miguel. O Som e o sentido: uma outra história das músicas. São Paulo: Companhia das Letras, 1989.

Discos:

PIXINGUINHA. Pixinguinha 100 Anos. Gravadora BMG, 1977.

K-XIMBINHO (s.d.). Saudades de um clarinete. K-Ximbinho: composição, regência e clarinete. São Paulo: Gravadora Eldorado,1981 (CD digital estéreo).

\section{Sites da Internet:}

Site oficial de Pixinguinha. Disponível em www.pixinguinha.com.br . Acesso em:Maio/2009

www.samba-choro.com.br . Acesso em Jun/2008.

www.ims.com.br . Acesso em maio/2008.

Stokovsky caçado. Disponível em www.daniellathompson.com .Acesso em Dez/2008.

NETLL, Bruno. "Improvisation". Disponível em www.grovemusic.com. Acesso em Nov/2008.

Fotos de Pixinguinha. Disponível em www.mpbantiga.blogspot.com . Acesso em Fev/2009.

\section{DISCOGRAFIA:}

COLTRANE, John. Giant Steps. Atlantic Records, 1960.

DESMOND, Paul. Pure Desmond. New York: CBS Inc, 1975.

FRANCESCHI, Humberto Moraes. A Casa Edison e seu tempo. CDs anexos à publicação. Rio de Janeiro: Sarapuí, 2002. 
K-XIMBINHO. Saudades de um clarinete. K-Ximbinho: composição, regência e clarinete. São Paulo: Gravadora Eldorado,1981 (CD digital estéreo).

Em Ritmo de Dança vol. 3. Rio de Janeiro: Polydor, 1959.

PIXINGUINHA: 100 Anos. BMG, 1997.

\section{ANEXOS}




\section{I'm Old Fashioned}

Jerome Kern
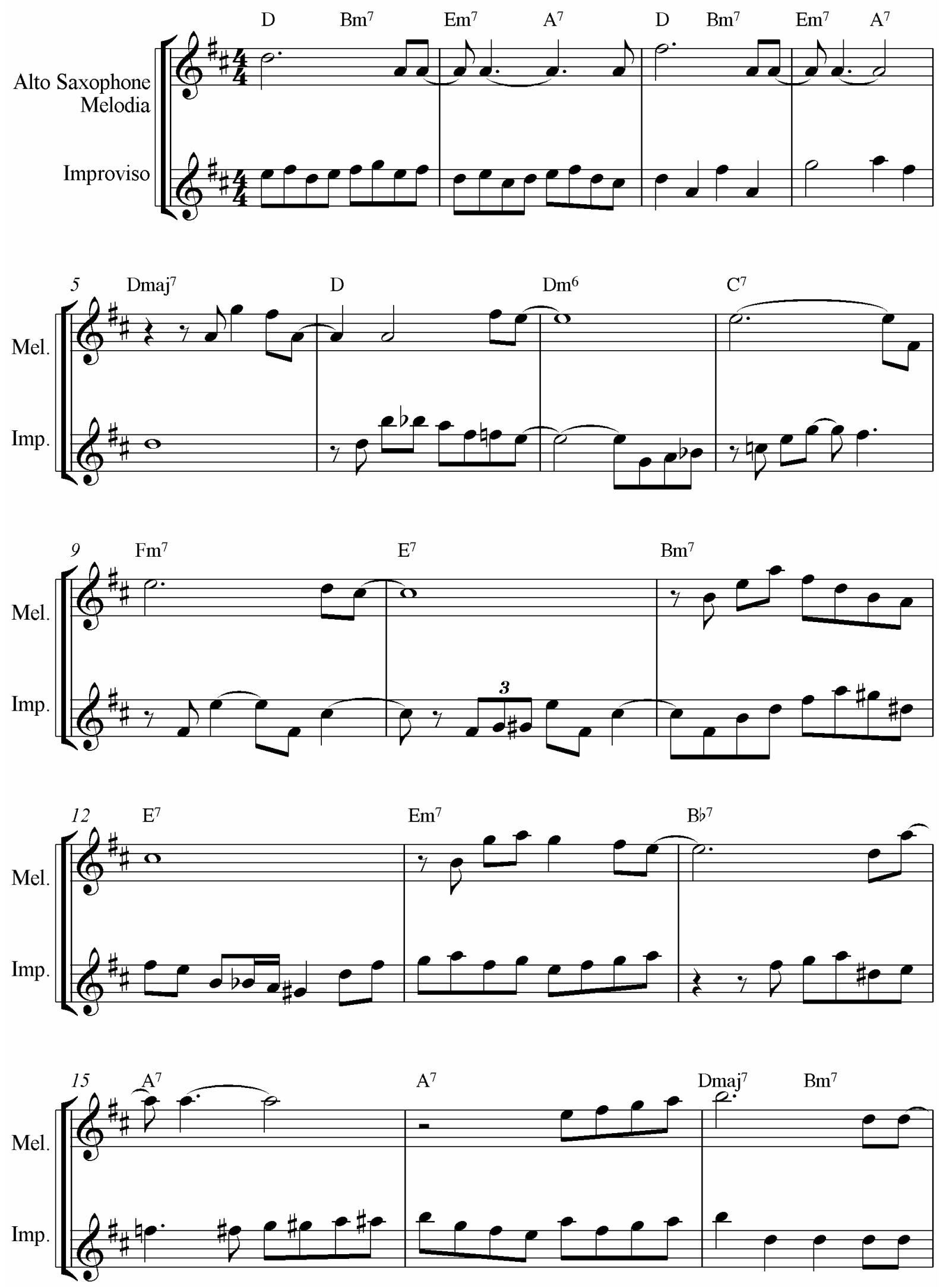

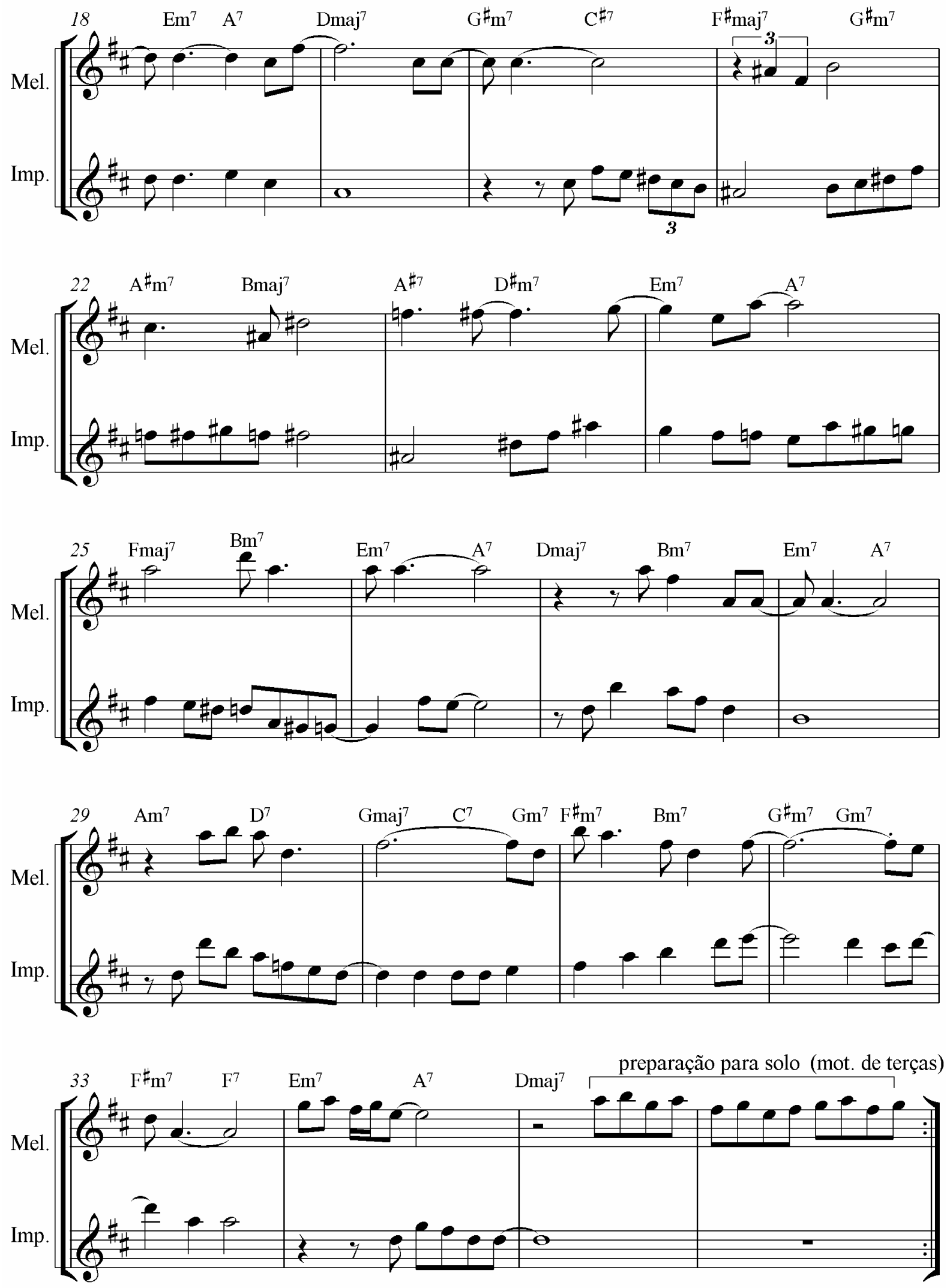


\section{Giant Steps}
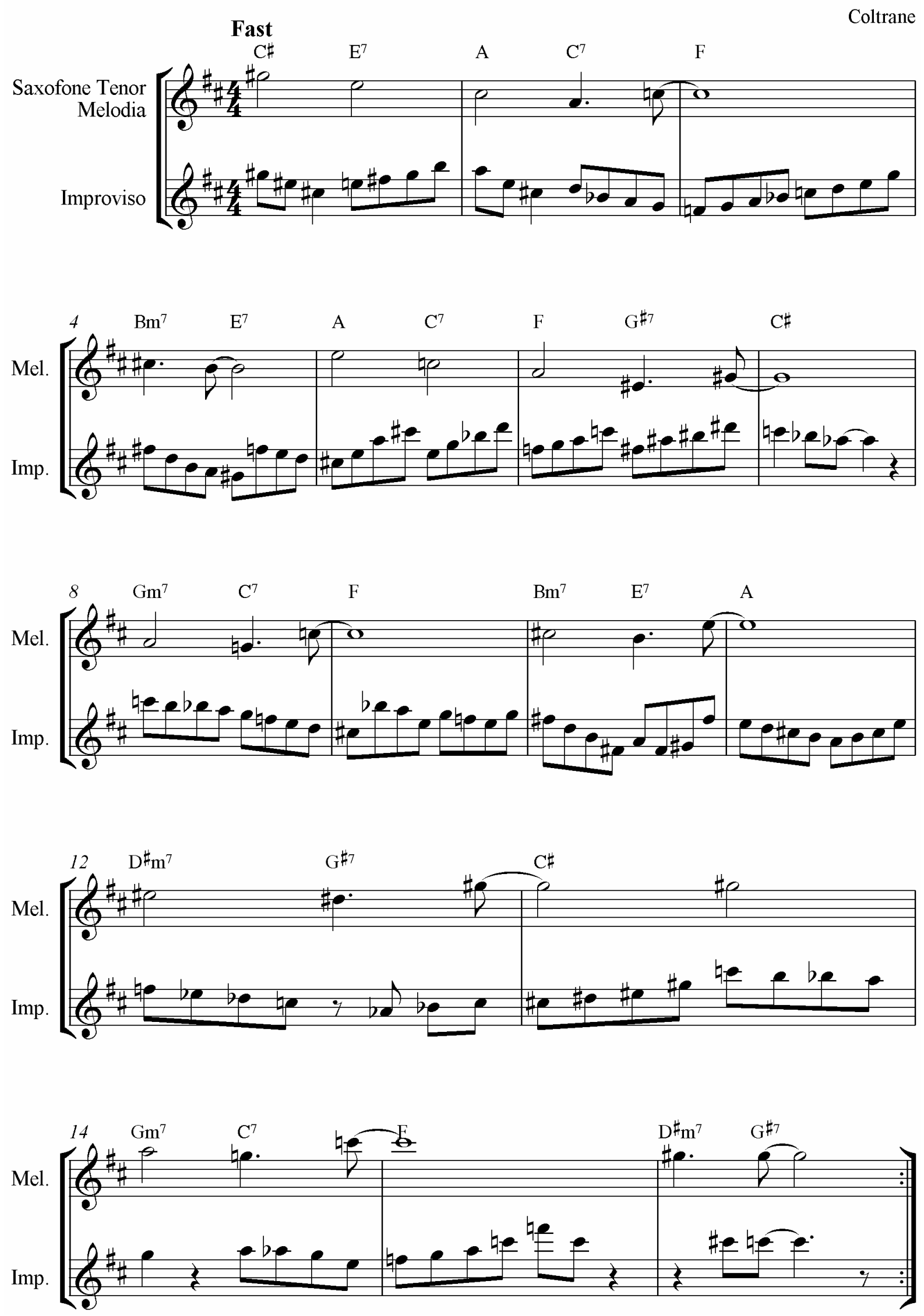
1 a 0

Choro Ligeiro
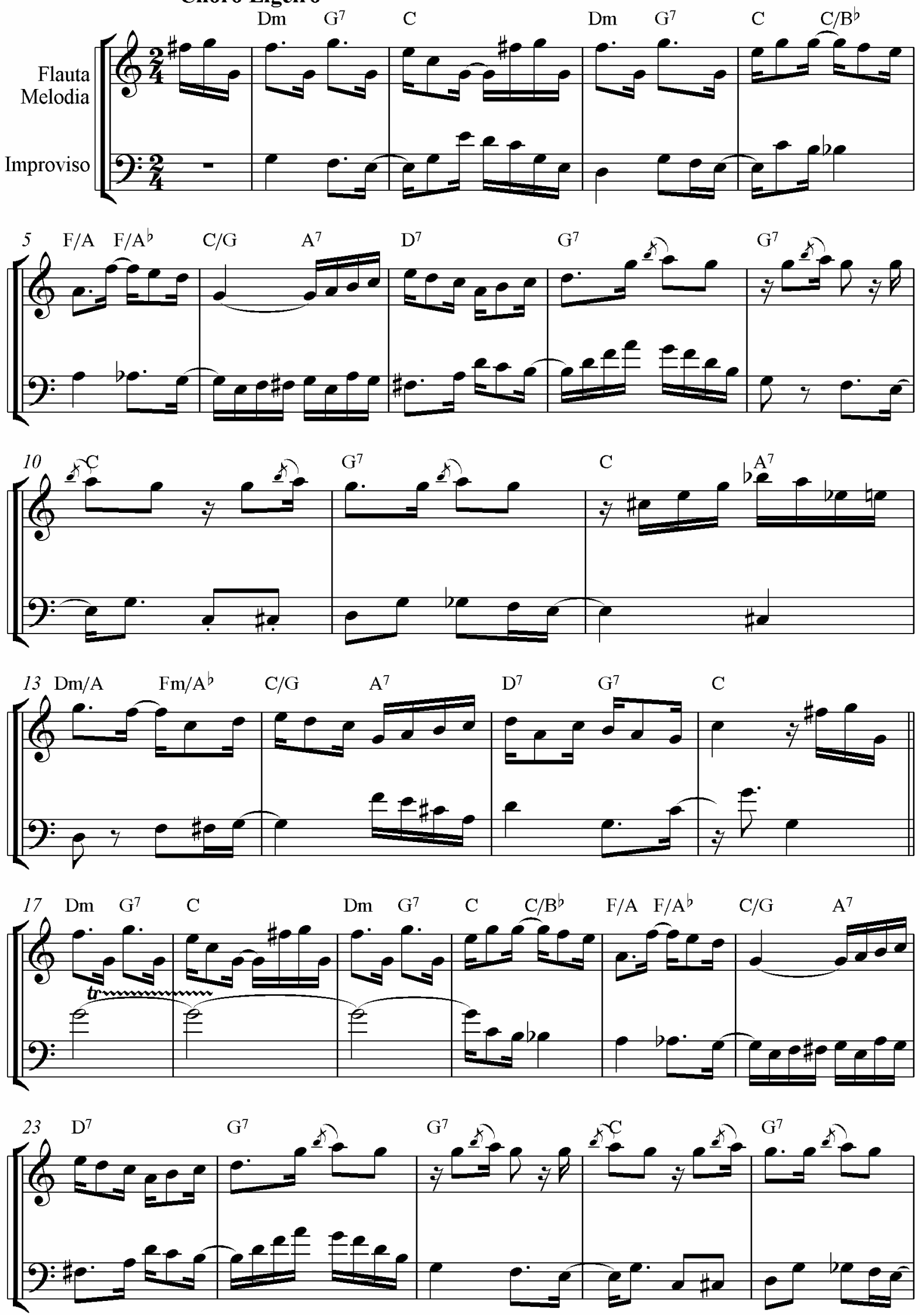

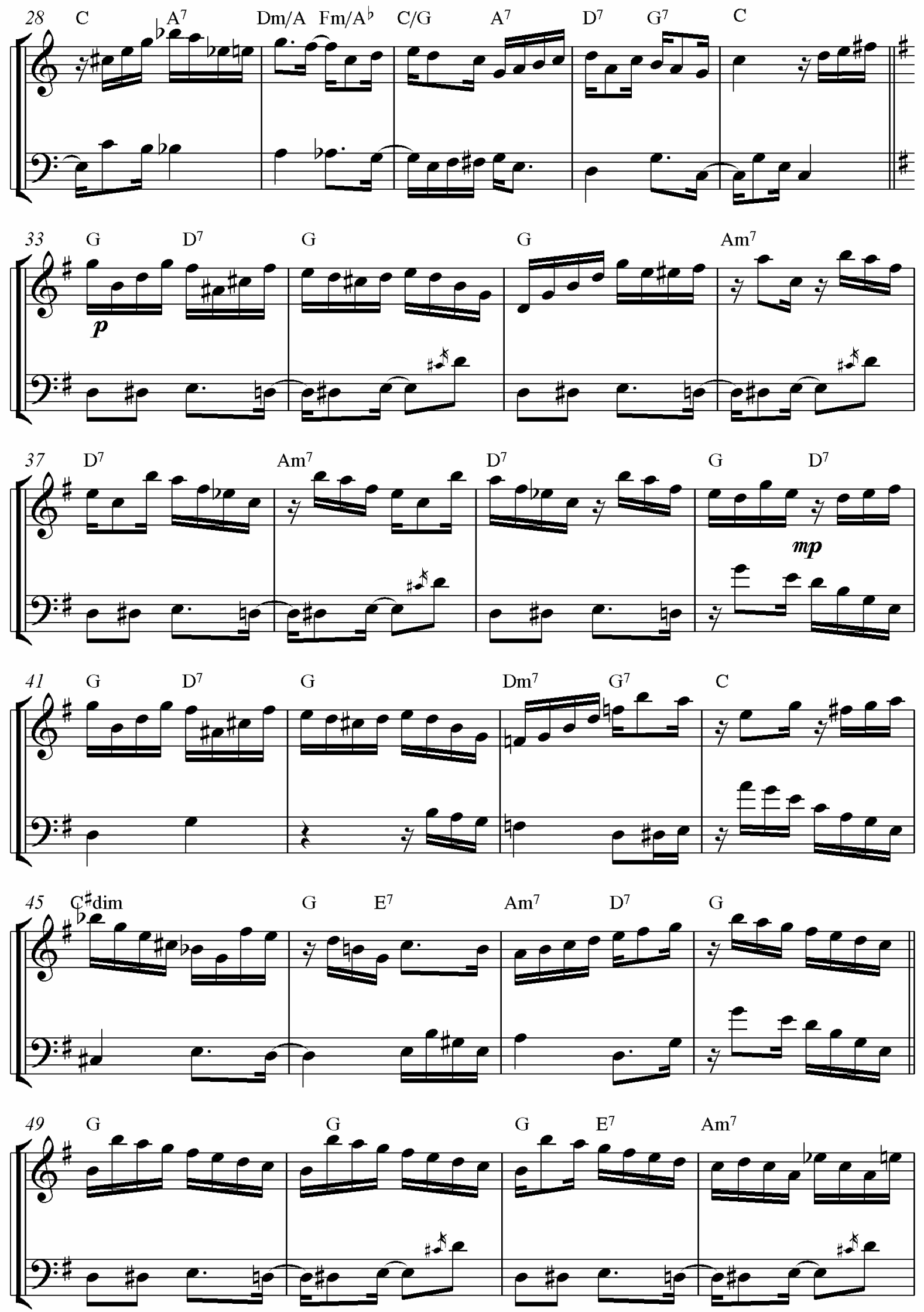

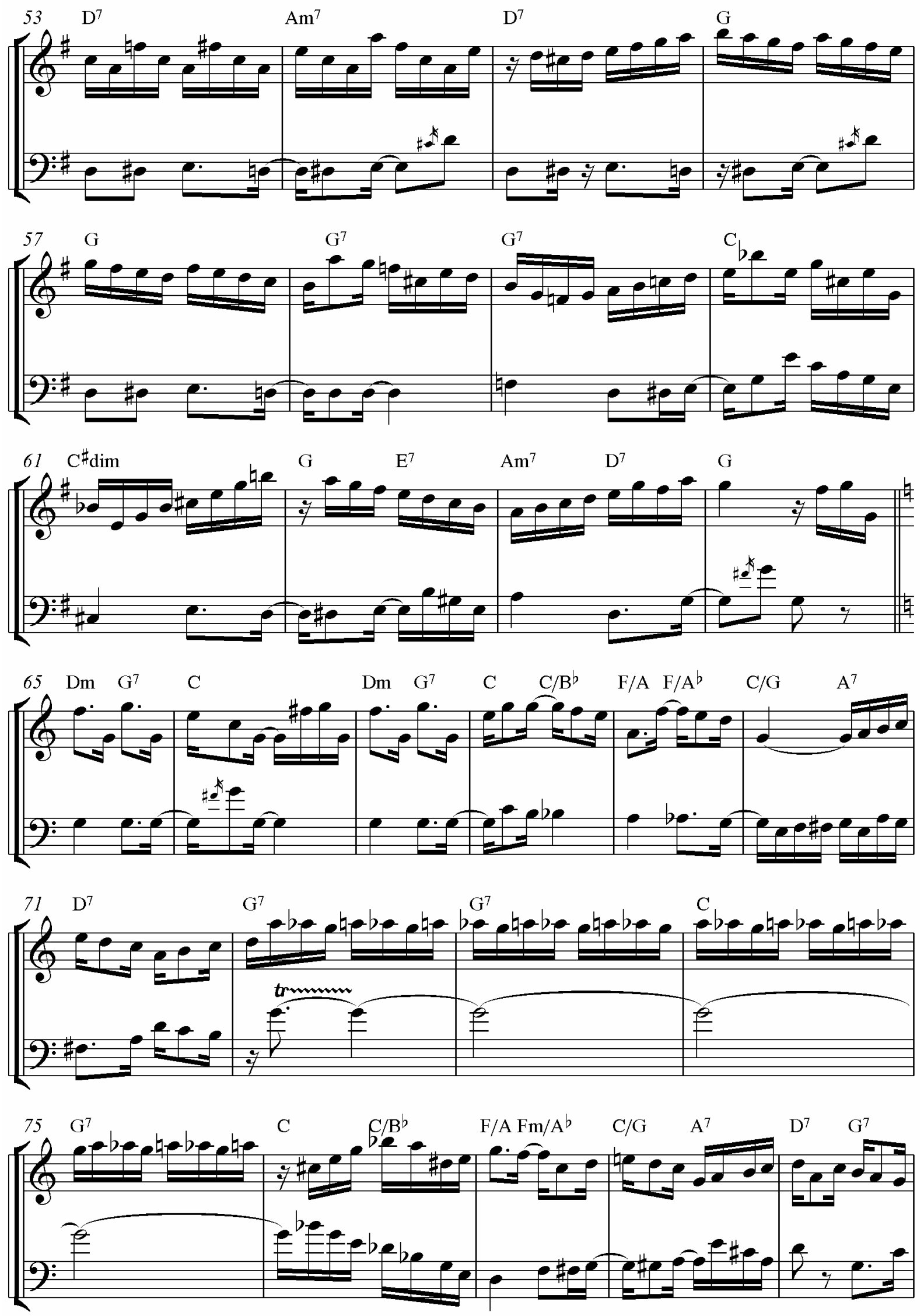

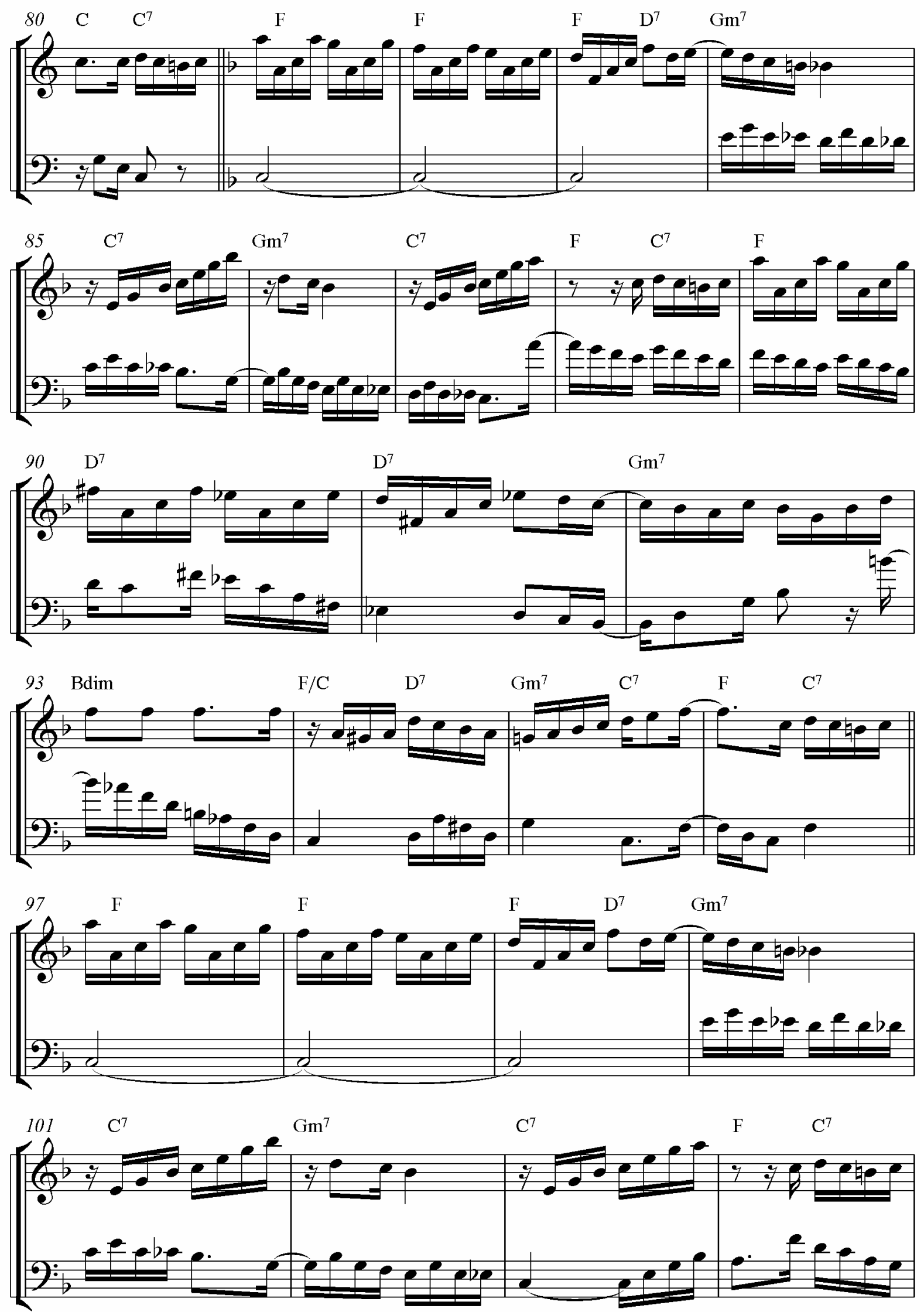

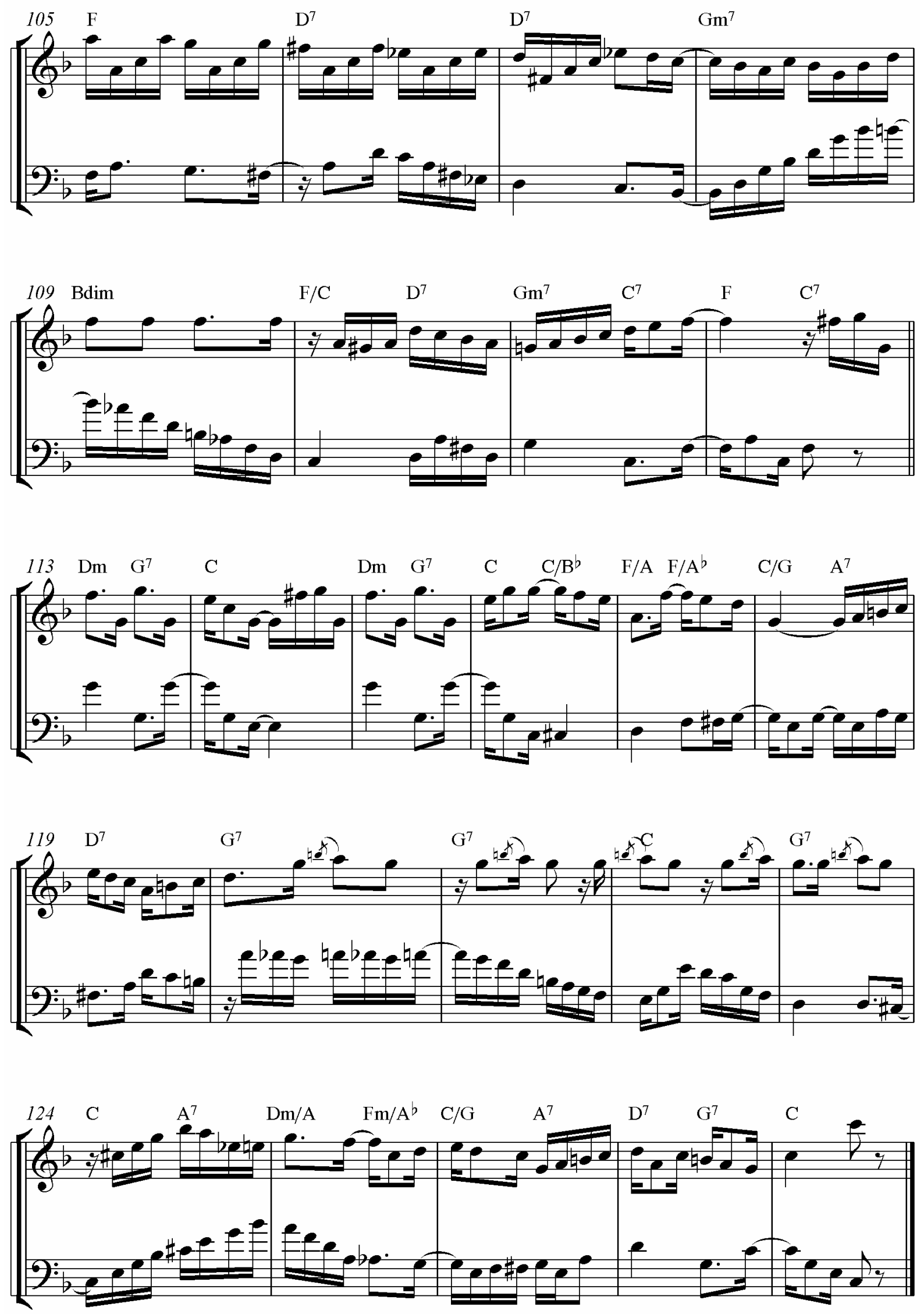
Pagão

Pixinguinha

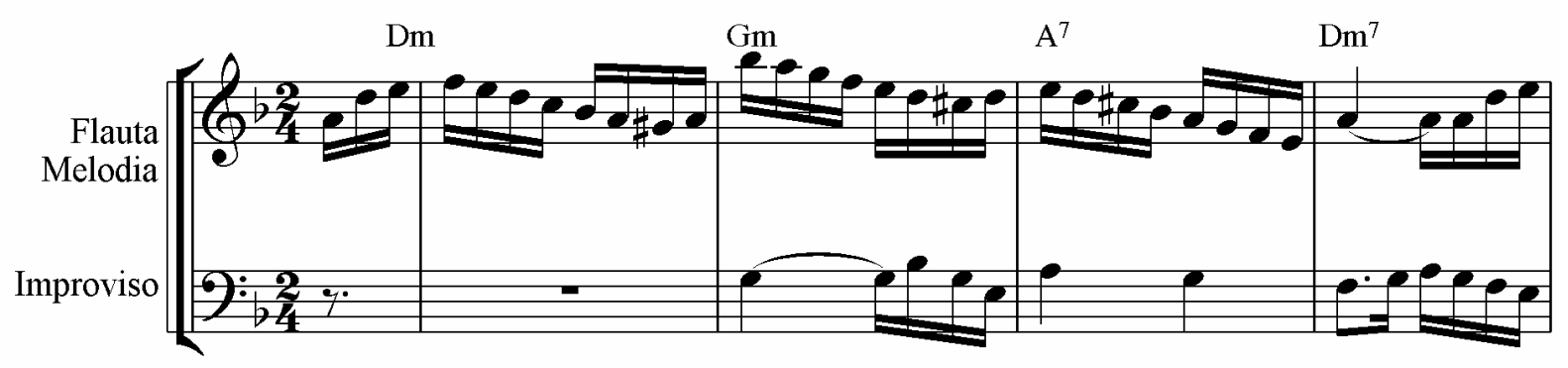

Fl.

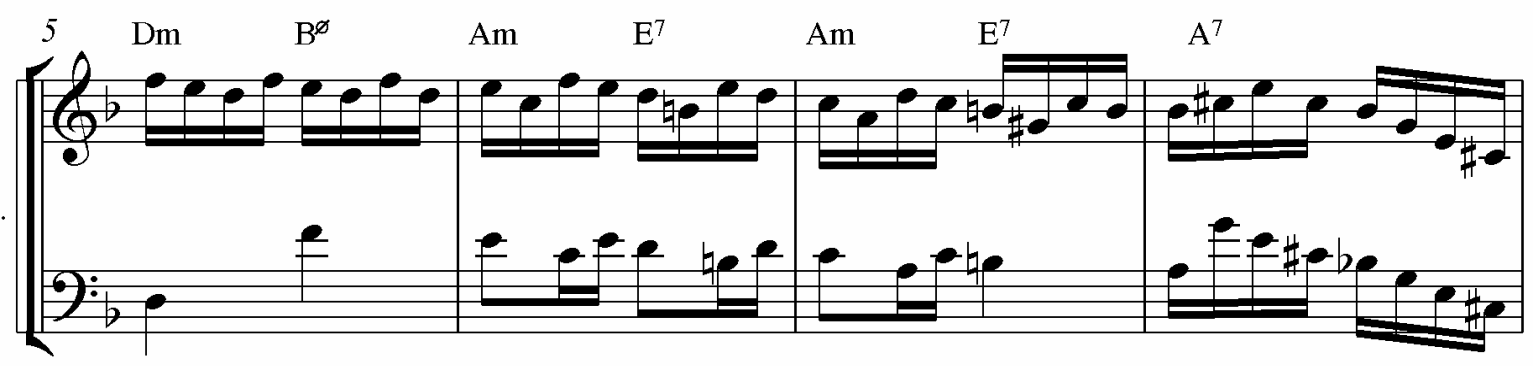

F1.

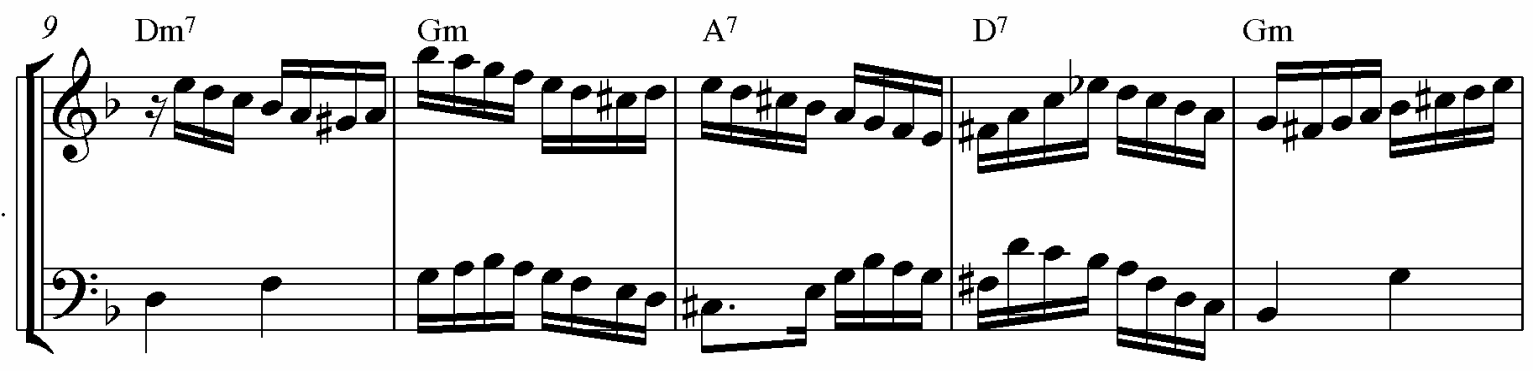

Fl.

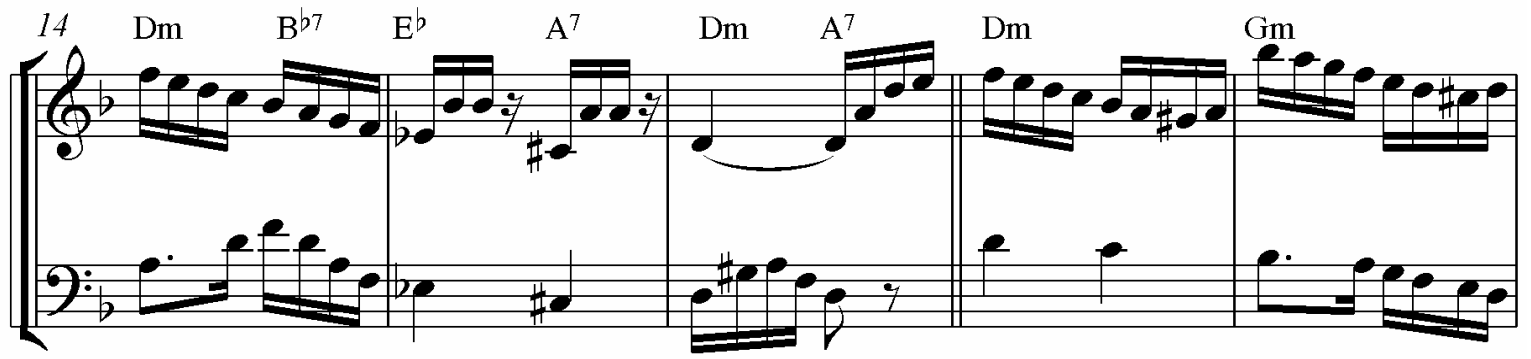

Fl.

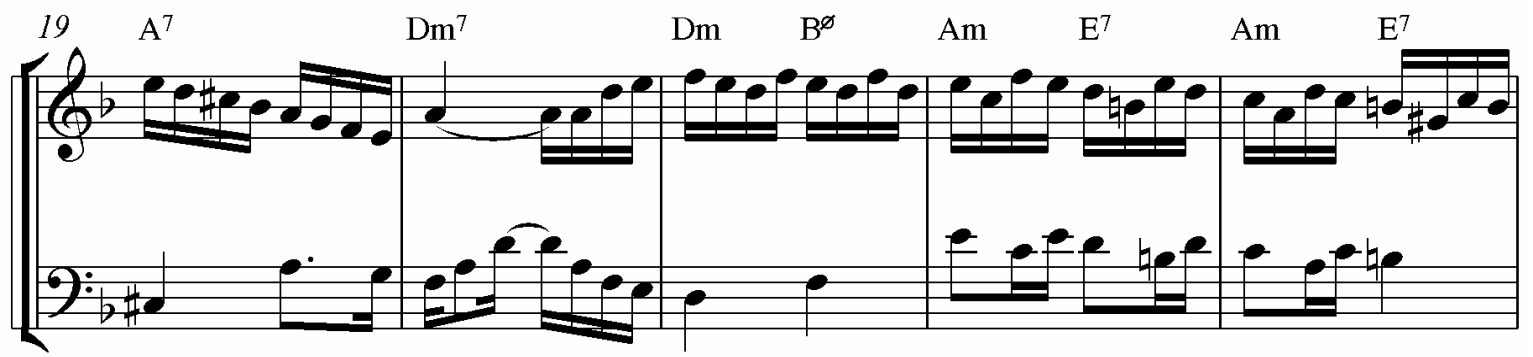




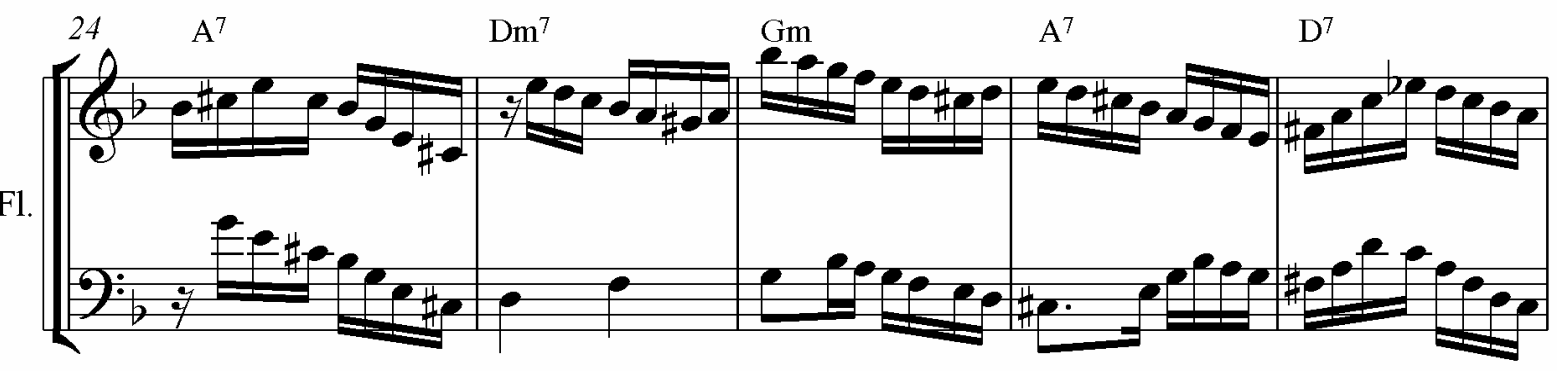

$\phi$
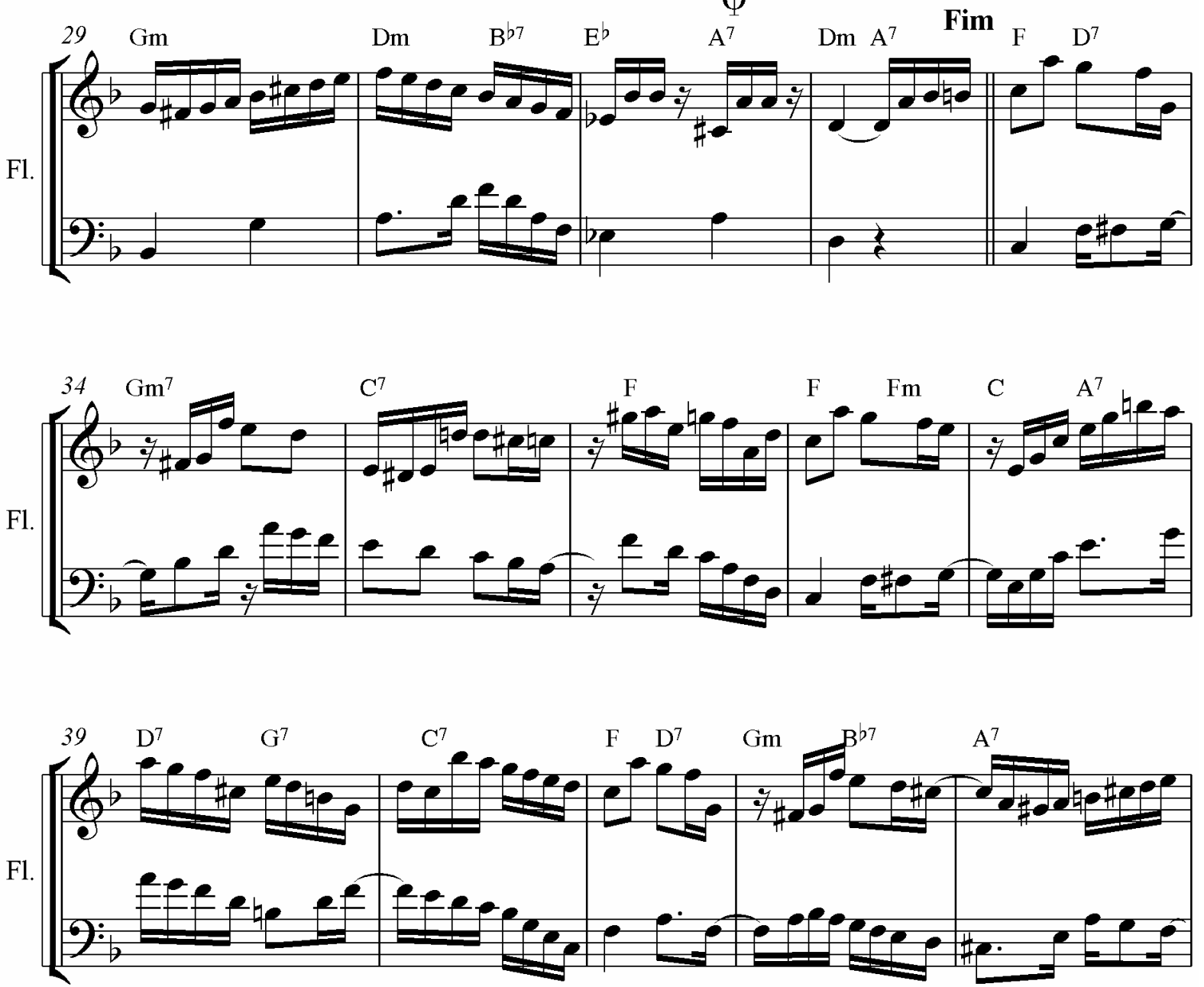

F1.

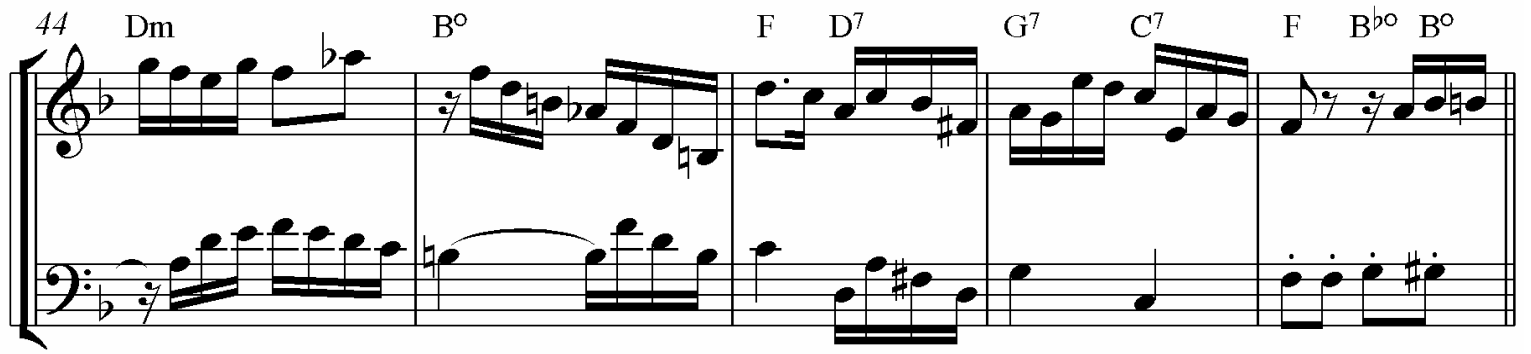


F1.

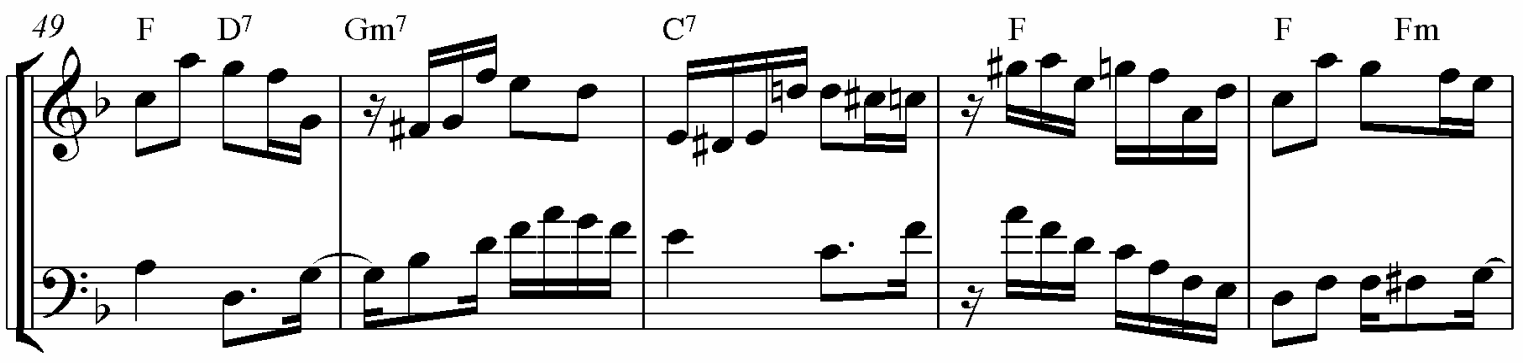

Fl.

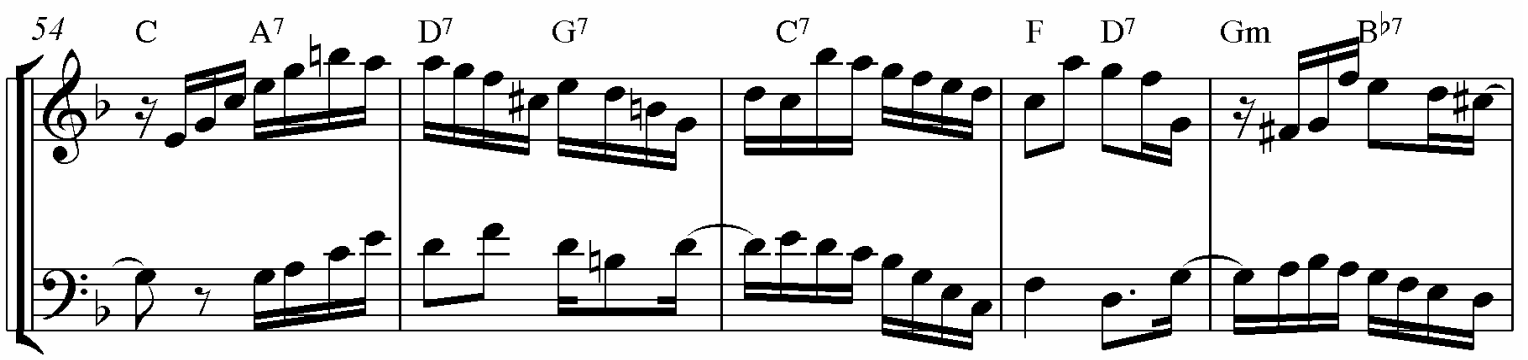

F1.

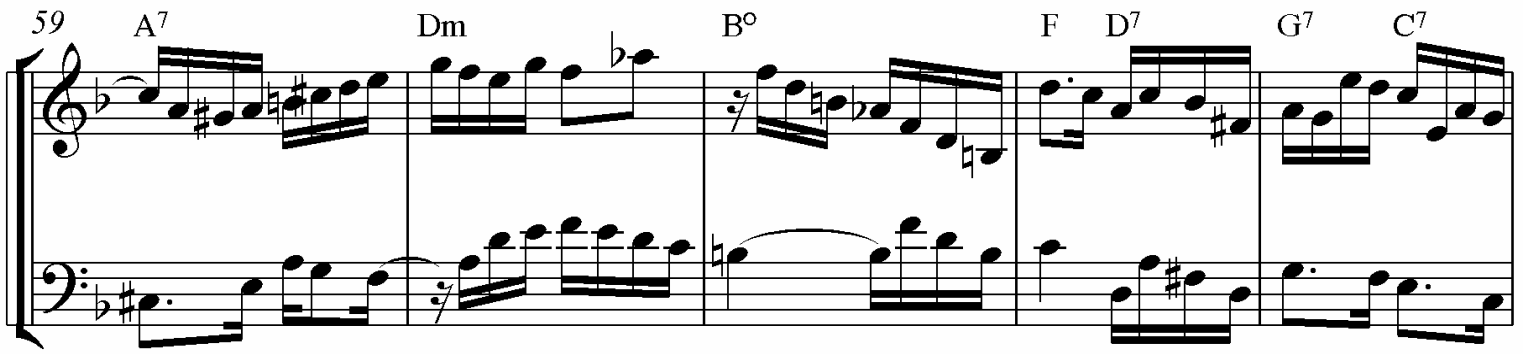

F1.
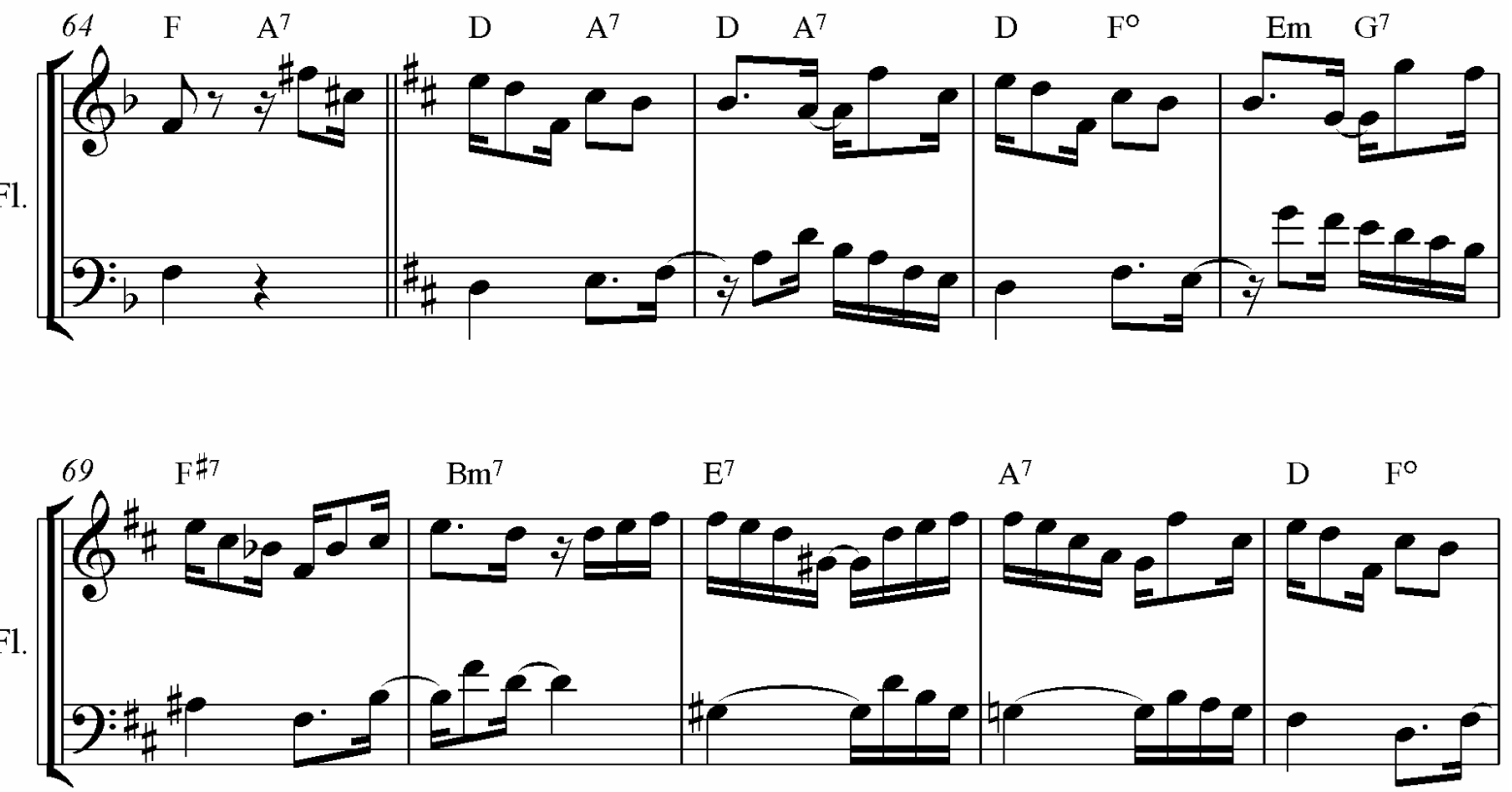

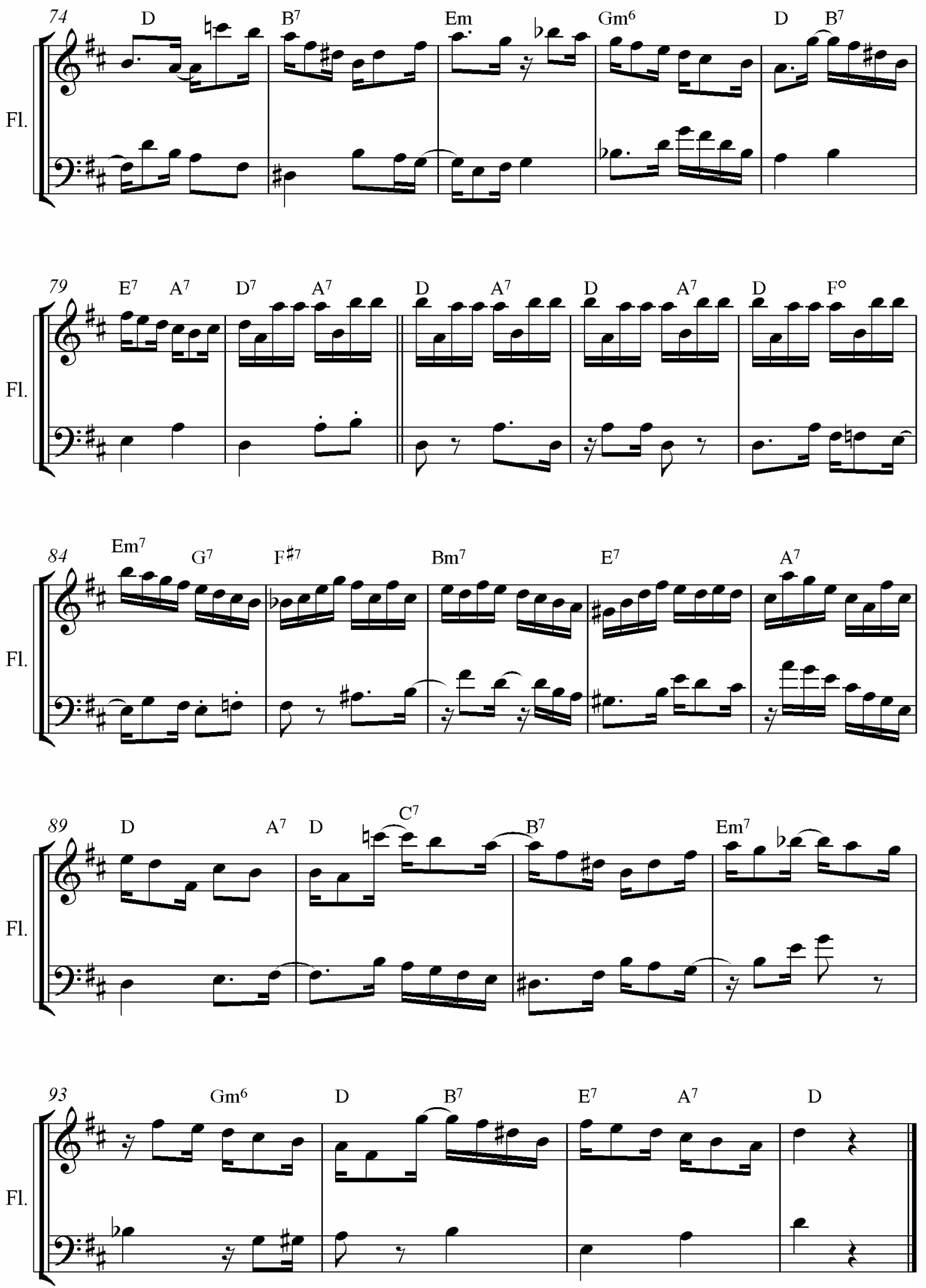

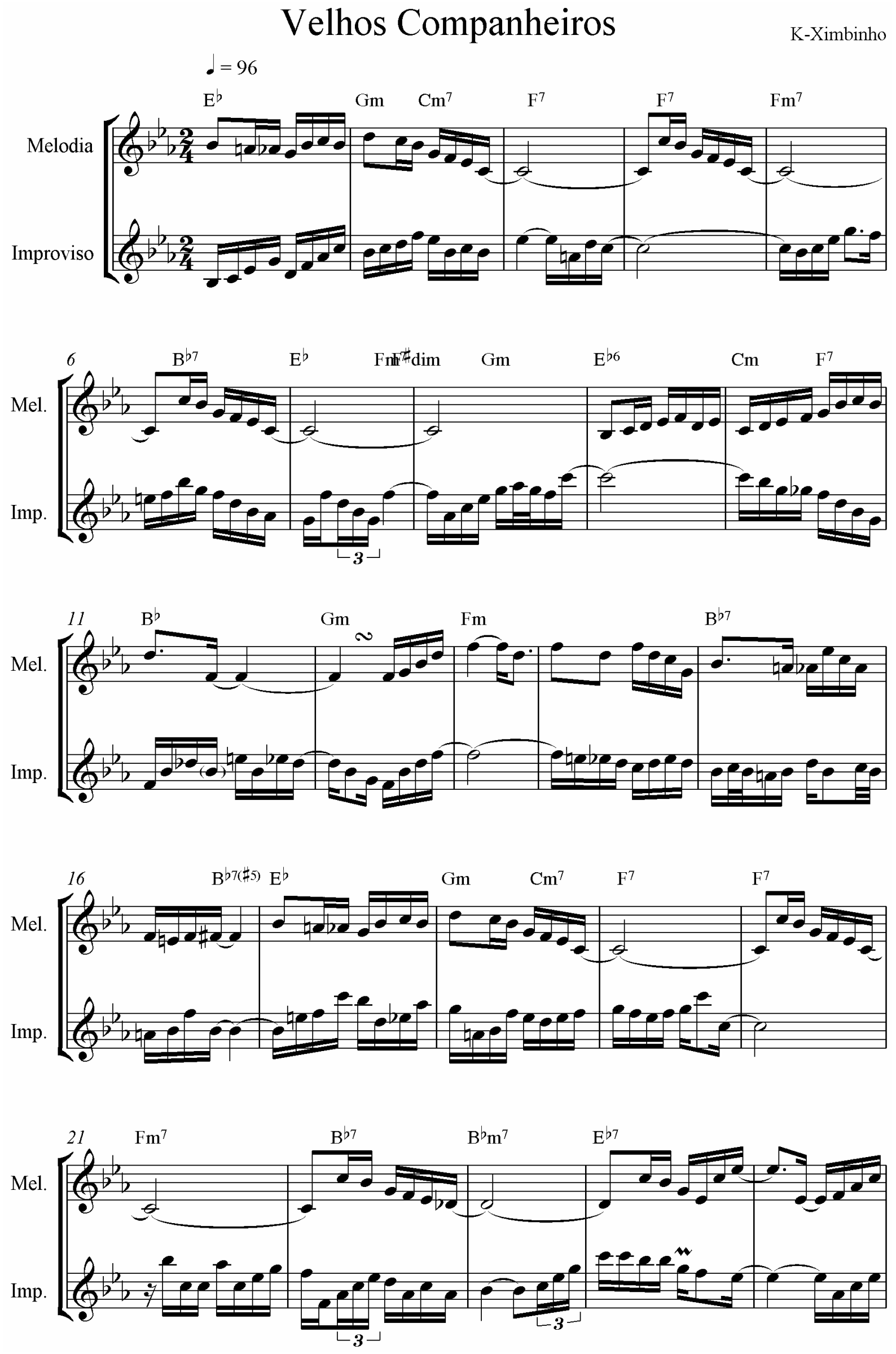
135

2

Velhos Companheiros
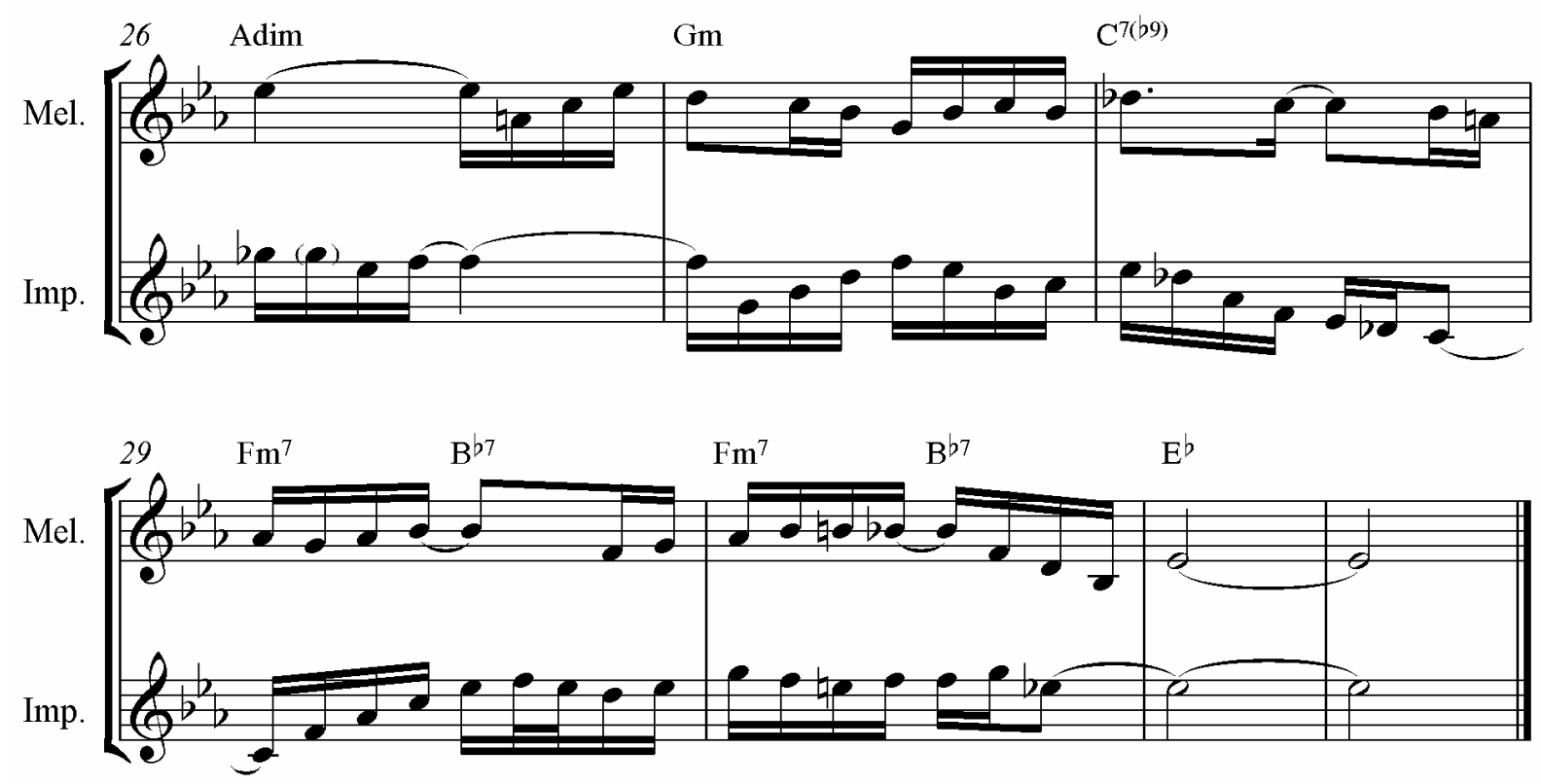


\section{Sempre}

$\downarrow=88$

K-Ximbinho

\section{F}

$\mathrm{D}^{7}$

$\mathrm{Gm}^{7}$

$\mathrm{C}^{7}$

$\mathrm{F}^{6}$

Flute

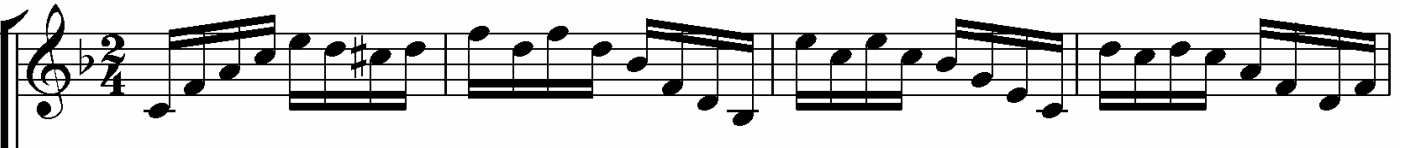

Improviso
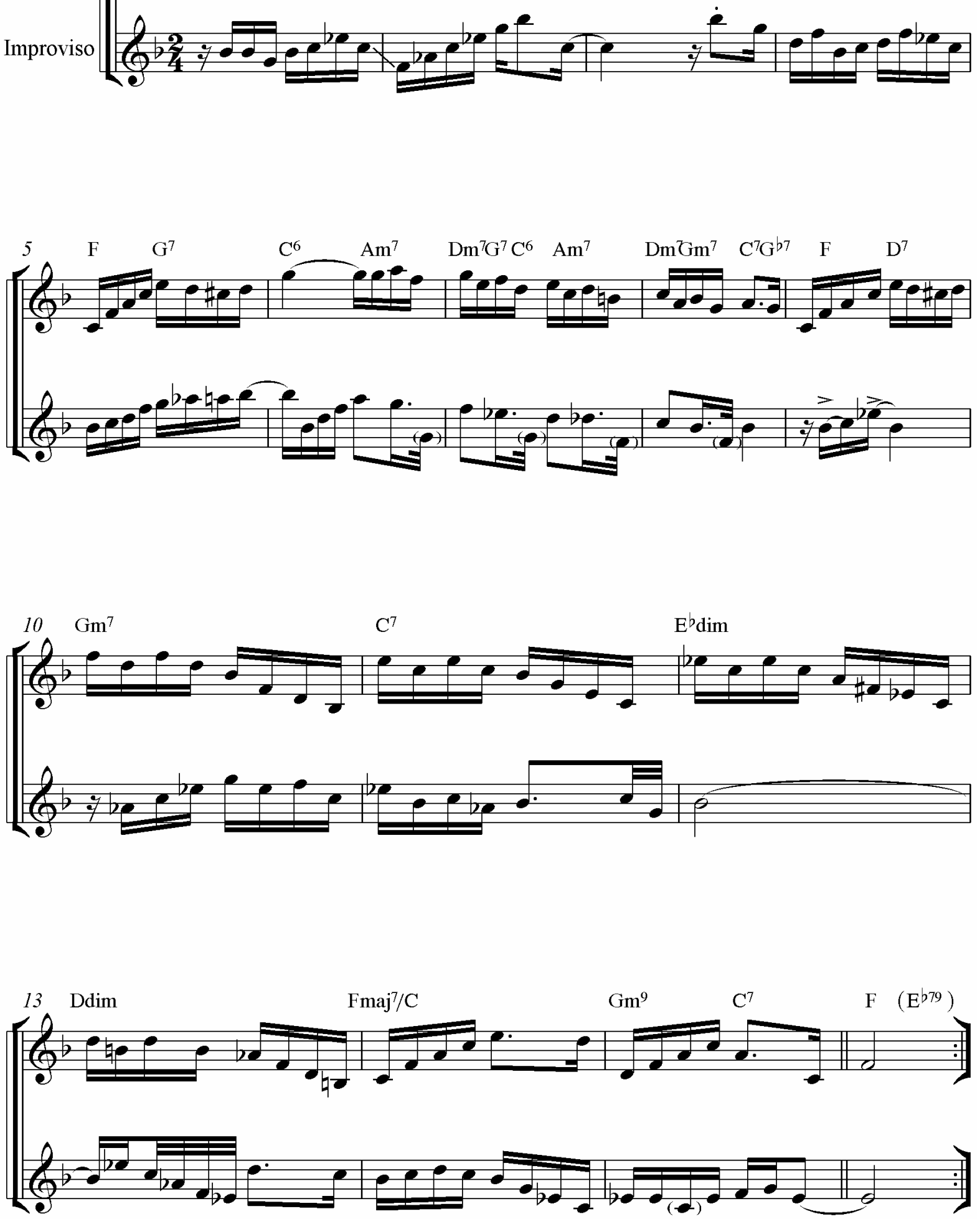

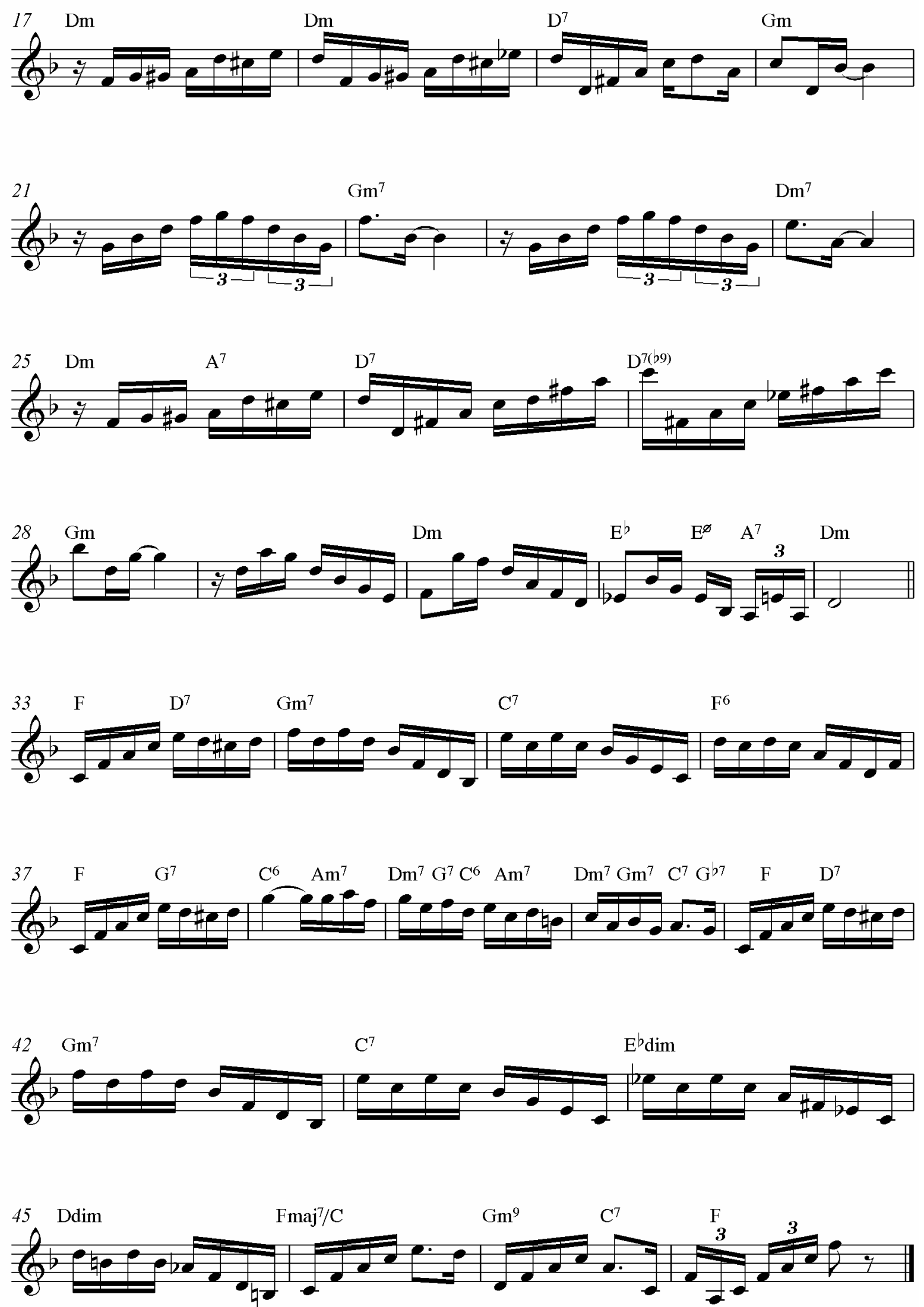


\section{Lá Vem a Baiana}

$\mathrm{A} b^{6}$
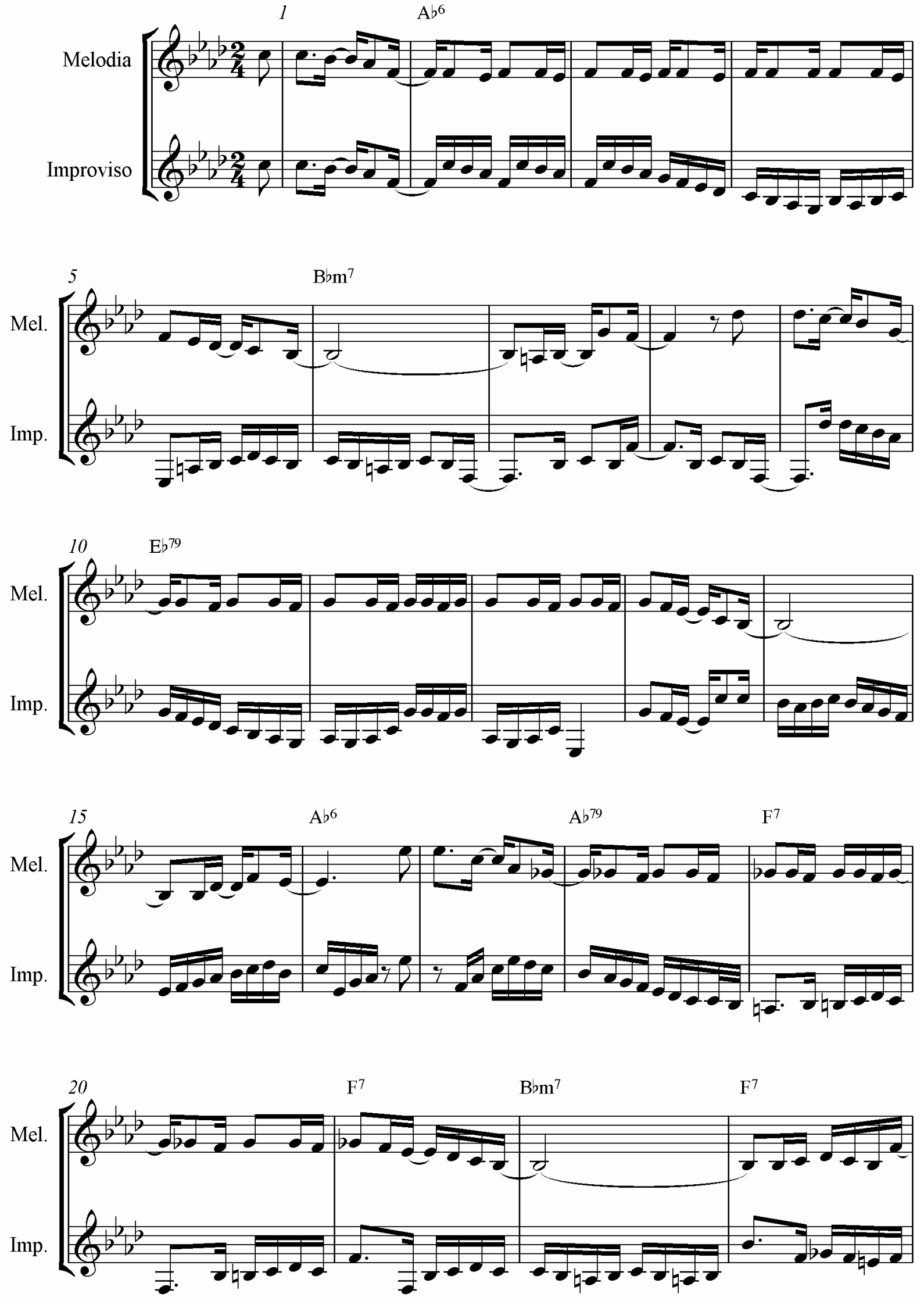

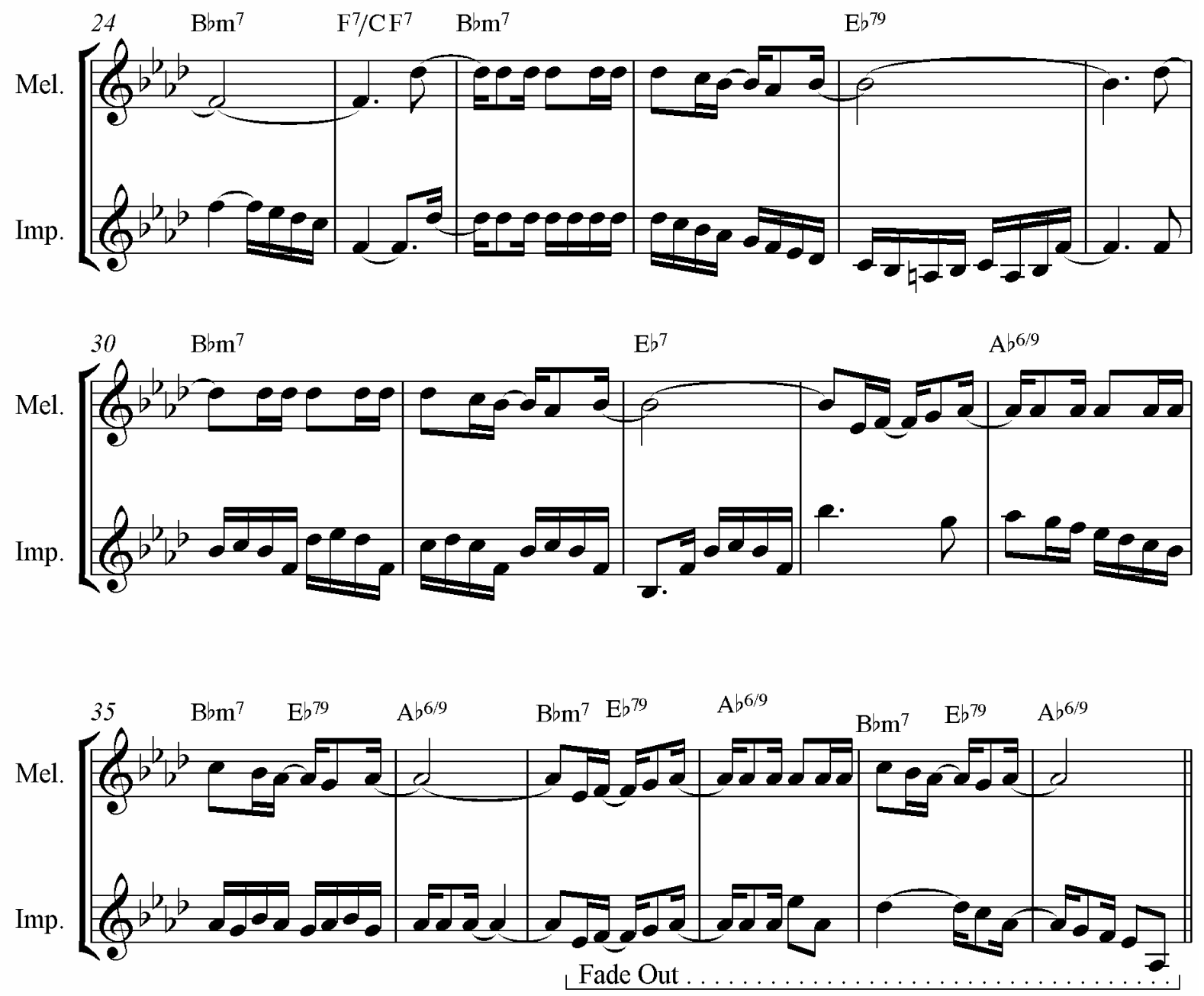

Mel.

Mel.

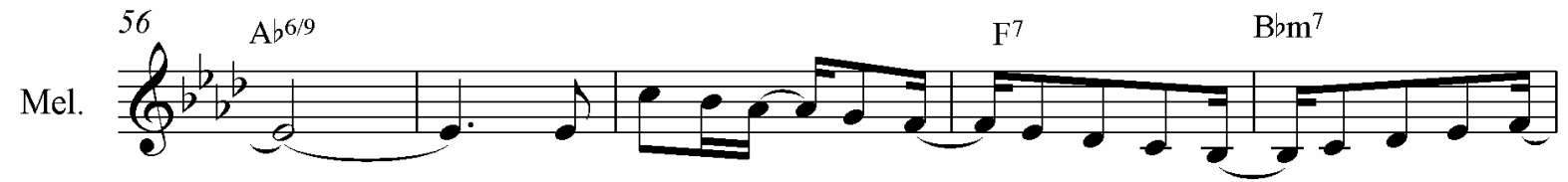

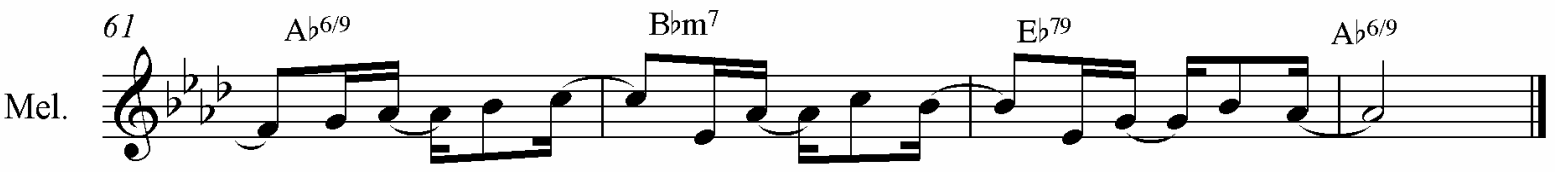

